Prepared in cooperation with the New Jersey Pinelands Commission and the Town of Hammonton, New Jersey

\title{
Assessment of Physical, Chemical, and Hydrologic Factors Affecting the Infiltration of Treated Wastewater in the New Jersey Coastal Plain, with Emphasis on the Hammonton Land Application Facility
}

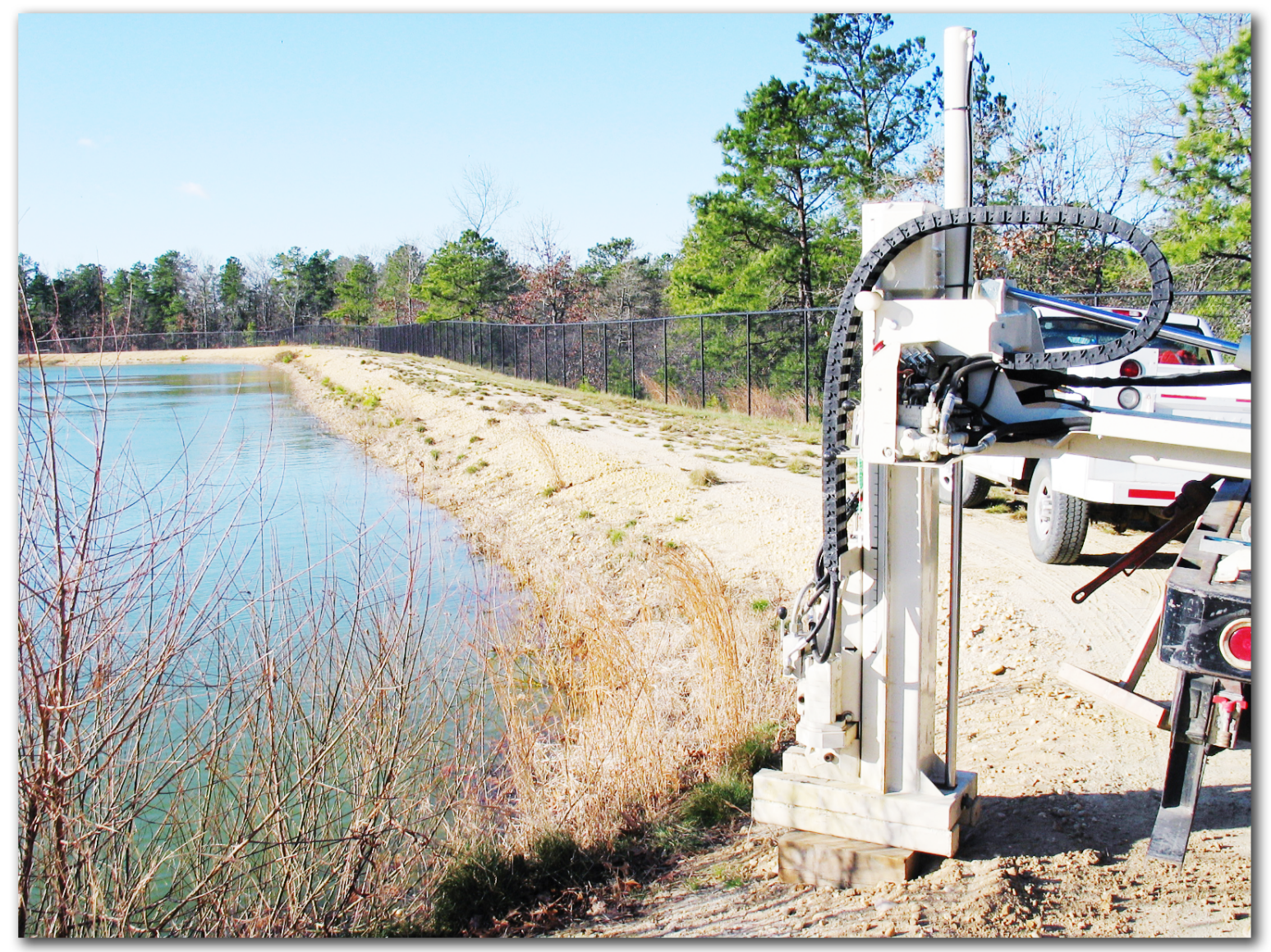

Scientific Investigations Report 2010-5006 
Cover. U.S. Geological Survey scientists prepare to collect soil cores using a direct push system adjacent to trench 2, Hammonton Land Application Facility, southern New Jersey. 


\section{Assessment of Physical, Chemical, and Hydrologic Factors Affecting the Infiltration of Treated Wastewater in the New Jersey Coastal Plain, with Emphasis on the Hammonton Land Application Facility}

By Timothy J. Reilly, Kristin M. Romanok, Steven Tessler, and Jeffrey M. Fischer

Prepared in cooperation with the New Jersey Pinelands Commission and the Town of Hammonton, New Jersey

Scientific Investigations Report 2010-5006 


\title{
U.S. Department of the Interior \\ KEN SALAZAR, Secretary \\ U.S. Geological Survey \\ Marcia K. McNutt, Director
}

\section{U.S. Geological Survey, Reston, Virginia: 2010}

\author{
For more information on the USGS — the Federal source for science about the Earth, its natural and living resources, \\ natural hazards, and the environment, visit http://www.usgs.gov or call 1-888-ASK-USGS \\ For an overview of USGS information products, including maps, imagery, and publications, \\ visit http://www.usgs.gov/pubprod \\ To order this and other USGS information products, visit http://store.usgs.gov
}

Any use of trade, product, or firm names is for descriptive purposes only and does not imply endorsement by the U.S. Government.

Although this report is in the public domain, permission must be secured from the individual copyright owners to reproduce any copyrighted materials contained within this report.

Suggested citation:

Reilly, T.J., Romanok, K.M., Tessler, S., and Fischer, J.M., 2010, Assessment of physical, chemical, and hydrologic factors affecting the infiltration of treated wastewater in the New Jersey Coastal Plain, with emphasis on the Hammonton Land Application Facility: U.S. Geological Survey Scientific Investigations Report 2010-5006, 59 p. 


\section{Contents}

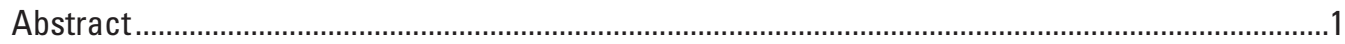

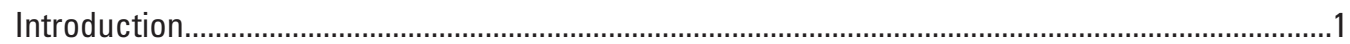

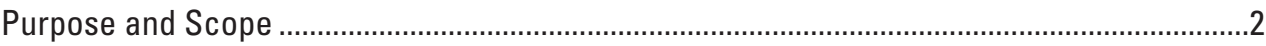

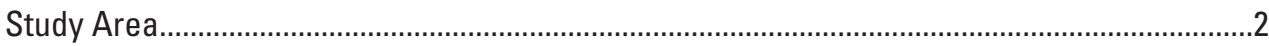

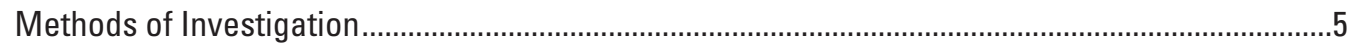

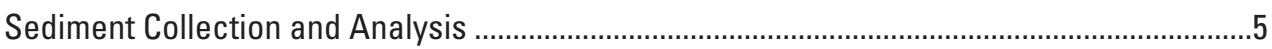

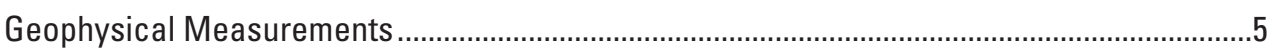

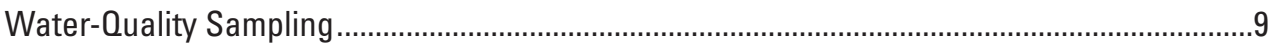

Quality Assurance..................................................................................................................

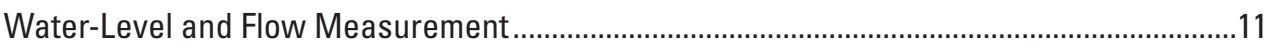

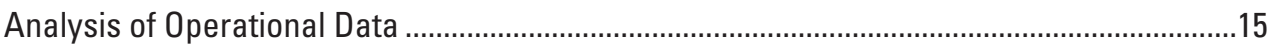

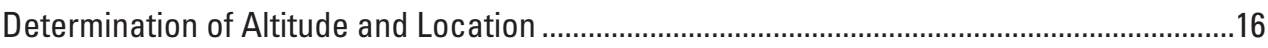

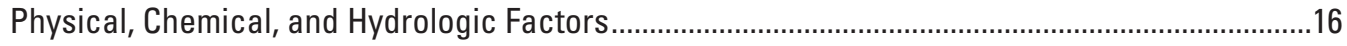

Hydrogeologic Framework ...................................................................................................16

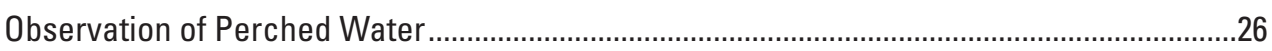

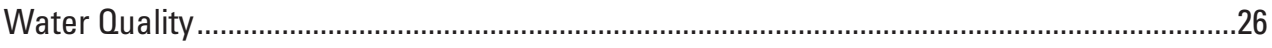

Operation and Condition of Infiltration Trenches ………….................................................34

Trench Wall Collapse and Infilling ........................................................................................36

Comparisons to other Pinelands Land Application Facilities .................................................36

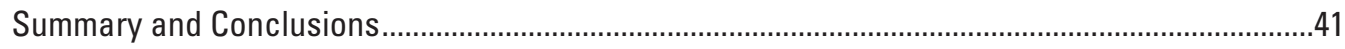

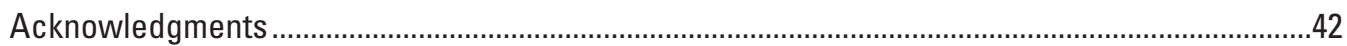

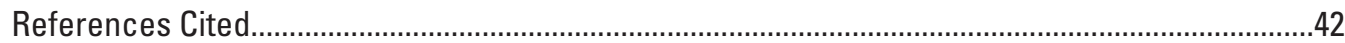

Appendix 1. Field parameters, nutrients, major ions, and trace elements in samples collected at the Hammonton Waste Water Treatment Plant and Land Application Facility, southern New Jersey, December 2006-May 2007..........................................................52

Appendix 2. Wastewater indicator compounds measured in samples collected the Hammonton Waste Water Treatment Plant and Land Application Facility, southern New Jersey, December 2006-May 2007.....................................................................53

Appendix 3. Results of blind-sample analyses for selected parameters by the U.S. Geological Survey, Branch of Quality Systems, November 2006-June 2007..................................54

Appendix 4. Lithologic description of continuous sediment cores, Hammonton Land Application Facility (LAF), southern New Jersey 


\section{Figures}

1-2. Map showing -

1. Locations of existing and proposed land application facilities within and near the Pinelands National Reserve, southern New Jersey...

2. Surficial geology underlying existing and proposed land application facilities within and near the Pinelands National Reserve, southern New Jersey... .4

3. Geologic section $A-A^{\prime}$ showing surficial geology in the vicinity of the Hammonton Land Application Facility in the Pinelands National Reserve, southern New Jersey.......5

4. Schematic diagram showing open-tube and closed-point soil sampler configurations

5. Map showing locations of wells, lagoon and trench sampling sites, infiltration tests, continuous sediment cores, and Hydraulic Profile Tool testing at the Hammonton Land Application Facility, southern New Jersey..

6. Photograph showing water-quality sampling in trench 2, Hammonton Land Application Facility, southern New Jersey.....

7. Geophysical logs of piezometer 6, Hammonton Land Application Facility, southern New Jersey.....

8. Map showing locations of wells, trenches, continuous sediment cores, Hydraulic Profiling Tool testing, and lines of section, Hammonton Land Application Facility, southern New Jersey......

9. Hydrogeologic cross sections $(A) B-B^{\prime},(B) C-C^{\prime},(C) D-D^{\prime},(D) E-E^{\prime}$, and $(E) F-F^{\prime}$, Hammonton Land Application Facility, southern New Jersey...

10. Geophysical logs of well Nest 11 MW C, Hammonton Land Application Facility, southern New Jersey.

11. Map showing locations of wells used to determine the altitude of perched water, Hammonton Land Application Facility, southern New Jersey.

12-18. Graphs showing-

12. Concentrations of selected ions in $(A)$ 24-hour composite samples of treated effluent collected at the Hammonton Waste Water Treatment Plant on December 2, 2006, and May 2, 2007; (B) samples of treated wastewater collected from the storage lagoons at the Hammonton Land Application Facility (LAF) on December 6, 2006, and May 3, 2007; and (C) samples of treated wastewater collected from trench 2 at the Hammonton LAF on December 5 and 7, 2006, and May 3, 2007, southern New Jersey

13. Concentrations of selected nutrients in $(A)$ 24-hour composite samples of treated effluent collected at the Hammonton Waste Water Treatment Plant on December 2, 2006, and May 2, 2007; (B) samples of treated wastewater collected from the storage lagoons at the Hammonton Land Application Facility (LAF) on December 6, 2006, and May 3, 2007; and (C) samples of treated wastewater collected from trench 2 at the Hammonton LAF on December 5 and 7, 2006, and May 3, 2007, southern New Jersey.

14. Concentrations of selected trace elements in $(A)$ 24-hour composite samples of treated effluent collected at the Hammonton Waste Water Treatment Plant on December 2, 2006, and May 2, 2007; (B) samples of treated wastewater collected from the storage lagoons at the Hammonton Land Application Facility (LAF) on December 6, 2006, and May 3, 2007; and (C) samples of treated wastewater collected from trench 2 at the Hammonton LAF on December 5 and 7, 2006, and May 3, 2007, southern New Jersey 
15. Relation between concentrations of sodium and chloride ions in samples of treated wastewater from selected locations within the Hammonton Waste Water Treatment Plant and Land Application Facility, southern New Jersey ........30

16. Relation between concentrations of boron and chloride ions in samples of treated wastewater from selected locations within the Hammonton Waste Water Treatment Plant and Land Application Facility, southern New Jersey ........30

17. Relation between concentrations of boron and nitrate plus nitrite ions in treated wastewater from selected locations within the Hammonton Waste Water Treatment Plant and Land Application Facility, southern New Jersey ........30

18. Relation between total concentration and number of wastewater indicator compounds detected in samples of treated wastewater from selected locations within the Hammonton Waste Water Treatment Plant and Land Application Facility, southern New Jersey.

19. Map showng lines of section across trench 1 along which land-surface altitudes were measured, Hammonton Land Application Facility, southern New Jersey.

20. Vertical profiles across trench 1 showing land-surface altitudes along sections (A) $G-G^{\prime},(B) H-H^{\prime},(C) I-I^{\prime}$, and $(D) J-J^{\prime}$, Hammonton Land Application Facility, southern New Jersey.

21. Photograph showing erosional features of the southern wall of trench 1 , Hammonton Land Application Facility, southern New Jersey...

22. Graphs showing comparison of results of Hydraulic Profiling Tool tests conducted at selected existing and proposed land application facilities in southern New Jersey. 


\section{Tables}

1. Selected well-construction information and date of natural gamma logging for monitoring wells and piezometers, Hammonton Land Application Facility, southern New Jersey

2. Analyses of samples collected from groundwater and treated wastewater from Hammonton Waste Water Treatment Plant and Land Application Facility, southern New Jersey, November 2006-May 2007

3. Quality-assurance and associated environmental data for (A) major ions, nutrients, and trace elements in samples collected at the Hammonton Land Application Facility, southern New Jersey, November 2006-May 2007; and (B) wastewater indicator compounds in filtered samples collected at the Hammonton Land Application Facility, southern New Jersey, May 2007

4. Well-constuction information, water levels, and altitudes of wells and trenches used to determine altitude of perched water tables, Hammonton Land Application Facility, southern New Jersey

5. Water-quality data collected, including field parameters, nutrients, major ions, and trace elements, at sites located at the Hammonton Waste Water Treatment Plant and Land Application Facility, southern New Jersey,

November 2006-May 2007

6. Wastewater indicator compounds detected in samples collected at Hammonton Waste Water Treatment Plant and Land Application Facility, southern New Jersey, November 2006-May 2007

7. Occurence and concentrations of wastewater indicator compounds and their possible uses or sources, Hammonton Land Application Facility, southern New Jersey

8. Infiltration and loading rates observed in (A) trench 1, (B) trench 2, and (C) trench 3, Hammonton Land Application Facility, southern New Jersey, 2002-07. 


\section{Conversion Factors and Datums}

\begin{tabular}{|c|c|c|}
\hline Multiply & By & To obtain \\
\hline \multicolumn{3}{|c|}{ Length } \\
\hline inch (in.) & 2.54 & centimeter $(\mathrm{cm})$ \\
\hline foot $(\mathrm{ft})$ & 0.3048 & meter $(\mathrm{m})$ \\
\hline mile (mi) & 1.609 & kilometer $(\mathrm{km})$ \\
\hline \multicolumn{3}{|c|}{ Area } \\
\hline acre & 4,047 & square meter $\left(\mathrm{m}^{2}\right)$ \\
\hline acre & 0.004047 & square kilometer $\left(\mathrm{km}^{2}\right)$ \\
\hline square foot $\left(\mathrm{ft}^{2}\right)$ & 0.09290 & square meter $\left(\mathrm{m}^{2}\right)$ \\
\hline \multicolumn{3}{|c|}{ Volume } \\
\hline gallon (gal) & 3.785 & liter (L) \\
\hline million gallons (Mgal) & 3,785 & cubic meters $\left(\mathrm{m}^{3}\right)$ \\
\hline cubic foot $\left(\mathrm{ft}^{3}\right)$ & 0.02832 & cubic meter $\left(\mathrm{m}^{3}\right)$ \\
\hline \multicolumn{3}{|c|}{ Flow rate } \\
\hline inch per hour (in/h) & 2.54 & centimeter per hour $(\mathrm{cm} / \mathrm{h})$ \\
\hline million gallons per day (Mgal/d) & 3,785 & cubic meters per day $\left(\mathrm{m}^{3} / \mathrm{d}\right)$ \\
\hline ounce per minute & 29.57 & milliliter per minute $(\mathrm{mL} / \mathrm{min})$ \\
\hline
\end{tabular}

Vertical coordinate information is referenced to the North American Vertical Datum of 1988 (NAVD 88).

Horizontal coordinate information is referenced to the North American Datum of 1983 (NAD 83).

Altitude, as used in this report, refers to distance above the vertical datum.

Specific conductance is given in microsiemens per centimeter at 25 degrees Celsius $\left(\mu \mathrm{S} / \mathrm{cm}\right.$ at $\left.25^{\circ} \mathrm{C}\right)$.

Concentrations of chemical constituents in water are given in either milligrams per liter (mg/L) or micrograms per liter $(\mu \mathrm{g} / \mathrm{L})$. 


\title{
Assessment of Physical, Chemical, and Hydrologic Factors Affecting the Infiltration of Treated Wastewater in the New Jersey Coastal Plain, with Emphasis on the Hammonton Land Application Facility
}

\author{
By Timothy J. Reilly, Kristin M. Romanok, Steven Tessler, and Jeffrey M. Fischer
}

\begin{abstract}
A hydrogeologic and water-quality investigation of the Hammonton Land Application Facility (Hammonton LAF) in Hammonton, New Jersey, was conducted to determine the factors that impede the infiltration of treated wastewater and to assess the potential for similar conditions to exist elsewhere in the Coastal Plain of New Jersey (particularly within the Pinelands National Reserve). Gamma logs, sediment cores, and hydraulic-profile testing indicate that extensive fine-grained strata and iron-cemented sands underlying the Hammonton LAF may impede infiltration and lead to the perching of diluted treated wastewater. Perched water was observed in augured holes adjacent to infiltration trenches, and analysis of wastewater loading and infiltration data indicates that infiltration trenches may receive lateral flow from multiple perched-water sources. Analysis of waterquality properties characteristic of treated wastewater show that although infiltrated wastewater is reaching the underlying aquifer, lengthy holding times and a long recharge pathway greatly reduce the concentrations of nitrate, boron, and many organic compounds typical of wastewater. Conditions at two currently operating facilities and one potential future facility in the New Jersey Coastal Plain were compared to those at the Hammonton Land Application Facility (LAF). Facilities operating as designed are not underlain by the restrictive strata that exist at the Hammonton LAF. Careful characterization of the geology and hydrology of the unsaturated zone underlying infiltration structures of future facilities in the New Jersey Coastal Plain and similar hydrogeologic settings will help to avoid constructing infiltration structures over or within low-hydraulic-conductivity strata that will decrease infiltration rates.
\end{abstract}

\section{Introduction}

The Pinelands National Reserve (PNR), created by the U.S. Congress in 1978, encompasses approximately 1.1 million acres of the New Jersey Coastal Plain. The PNR covers all or parts of 56 municipalities spread across seven counties, and contains unique plant and animal species. The New Jersey Pinelands Commission (Pinelands Commission) was created by the same Act to preserve, protect, and enhance the natural and cultural resources of the PNR, and to encourage compatible activities consistent with that purpose. The Pinelands Commission developed the Pinelands Comprehensive Management Plan (CMP) to guide the development of the PNR so that the area's unique cultural and natural resources would be protected (New Jersey Pinelands Commission, 2007). The intent of the regulations is to preserve the quantity of the groundwater in the sole-source Kirkwood-Cohansey aquifer system, and the quality of the PNR's surface water, which is naturally low in nutrients and supports unique biotic communities. The CMP prohibits sewage-treatment plants from discharging directly to any surface-water body.

In 1991, the New Jersey Department of Environmental Protection (NJDEP) directed the Town of Hammonton to upgrade its sewage-treatment plant and cease stream discharge to meet Pinelands and New Jersey Pollutant Discharge Elimination System (NJPDES) requirements. In response to the NJDEP directive, Hammonton constructed a new tertiarytreatment plant and land application facility (LAF). The new treatment plant was brought online in late 2001 and flow to the LAF was to be phased in during 2001-04. In its second year of operation (2002), the LAF was found to be capable of infiltrating a maximum of $0.6 \mathrm{Mgal} / \mathrm{d}$, far less than the design capacity of $1.6 \mathrm{Mgal} / \mathrm{d}$. Review of the treatment-system design 
Assessment of Factors Affecting the Infiltration of Treated Wastewater in the New Jersey Coastal Plain

and additional testing by the Town's engineering consultants did not identify the reason, or reasons, the LAF was not meeting its design specifications (Edward Wengrowski, New Jersey Pinelands Commission, oral commun., 2006). Understanding the nature of the problem(s) associated with the Hammonton LAF is critical, as anticipated development in this and other Pinelands towns will require construction of additional infiltration facilities or use of alternate methods to treat and dispose of treated wastewater.

\section{Purpose and Scope}

This report describes the results of a study, conducted by the U.S. Geological Survey (USGS) in cooperation with the Pinelands Commission and the Town of Hammonton, New Jersey, to identify reasons for reduced infiltration in the infiltration trenches at the Hammonton LAF and to assess the potential for similar conditions to exist elsewhere in the New Jersey Coastal Plain (particularly within the PNR). The report:

- Identifies specific conditions at the Hammonton LAF that inhibit infiltration. This objective includes an examination of sediment properties and changes in water quality at various points within the treatment and land application system that could provide evidence of the mechanism(s) responsible for reduced infiltration.

- Based on the conditions determined above, describes possible methods that could improve the operational efficiency of the current and future sites.

- Assesses the prevalence of similar conditions within and near the Pinelands National Reserve that are likely to inhibit infiltration at other LAFs.

- Provides information on site-specific and regional hydrologic constraints on design and siting to optimize the operational efficiency of future LAFs in southern New Jersey.

\section{Study Area}

The focus of this study is the Hammonton LAF in northwestern Atlantic County, New Jersey, within the Pinelands National Reserve (fig. 1). The Hammonton Waste Water Treatment Plant (WWTP) is permitted to treat $1.6 \mathrm{Mgal} / \mathrm{d}$ of mixed residential, commercial, and industrial wastewater (ARH Associates, 1989). On average, the WWTP receives and treats approximately $1.0 \mathrm{Mgal} / \mathrm{d}$ of wastewater (Anthony DeCicco, Town of Hammonton, written commun., 2009). Primary treatment is accomplished by a headworks that pulverizes and removes solids, and an associated lift station (ARH Associates, 1989). Secondary treatment occurs in an activated sludge/oxidation ditch. Before discharge, WWTP effluent is passed through clarifiers and multi-media filters to separate solids, aerated to increase the oxygen content, and treated with ultraviolet (UV) light to reduce microbiological pathogens (especially fecal coliform bacteria) (ARH Associates, 1989). Approximately two-thirds of the daily WWTP effluent is discharged directly to Hammonton Creek and one-third is transferred through a buried pipeline to a lined storage lagoon at the Hammonton LAF. Treated wastewater is then transferred to one of five infiltration trenches for disposal (only trenches 1, 2, and 3 were included in this study). Like the Hammonton LAF, municipal land application facilities for Sicklerville and Landis, and the site of the future Evesham township LAFs, which are also included in this study, are located in the New Jersey Coastal Plain. Unlike the Hammonton LAF, however, the Sicklerville and Landis LAFs are operating as designed. The investigation of the Sicklerville, Landis, and future Evesham Township sites was limited to brief site visits and the collection of direct-drive geophysical data.

The study area is in the Coastal Plain physiographic province. The Coastal Plain is a seaward-dipping wedge of unconsolidated sands and clays that range in age from Cretaceous to Holocene (Zapecza, 1989). Sediments that compose the unsaturated zone and the shallow aquifer underlying the Hammonton LAF are made up of the Miocene Bridgeton Formation and weathered Coastal Plain deposits (Newell and others, 2000) (figs. 2 and 3). The Bridgeton Formation is characterized by coarse, pebbly, orange sands and was deposited in the late Miocene Epoch in a former fluvial-plain environment (Zapecza, 1989; Newell and others, 2000). Erosion has dissected the Bridgeton Formation, which is present as the caps of hills in the Coastal Plain with a maximum thickness of about $40 \mathrm{ft}$ (Newell and others, 2000). The clay-sized fraction of the Bridgeton Formation is characterized by gibbsite, goethite, hematite, and halloysite; the presence of such an assemblage is indicative of prolonged subaerial exposure (Owens and others, 1983). The maximum thickness of the Bridgeton Formation underlying the Hammonton LAF is about $25 \mathrm{ft}$ (Newell and others, 2000). Newell and others (2000) describe weathered Coastal Plain deposits as exposures of weathered sands, silts, and clays overlain by thin alluvium and colluvium. The maximum thickness of the weathered Coastal Plain deposits underlying the Hammonton LAF is about $25 \mathrm{ft}$ (Newell and others, 2000). The Hammonton LAF is characterized by generally flat topography, with altitudes ranging from $110 \mathrm{ft}$ in the southern portion of the facility to $60 \mathrm{ft}$ along Hammonton Creek (ARH Associates, 1993). Typical depth to water is about $30 \mathrm{ft}$ below land surface and groundwater flow is generally from south to north (ARH Associates, 1993).

Other land application facilities in southern New Jersey considered in this study are underlain by several different surficial geologic formations (fig. 2). The Landis LAF is underlain by the late Pleistocene Lower Terrace deposits, consisting of pebble gravel with minor silt and cobble gravel (Newell and others, 2000). This unit is as much as $30 \mathrm{ft}$ thick and forms stream terraces with surfaces 5 to $20 \mathrm{ft}$ above the modern floodplain (Newell and others, 2000). Like the Hammonton LAF, the Sicklerville LAF is underlain by the Bridgeton Formation, but much of the native sediment has been removed and replaced with clean quartz sand. 


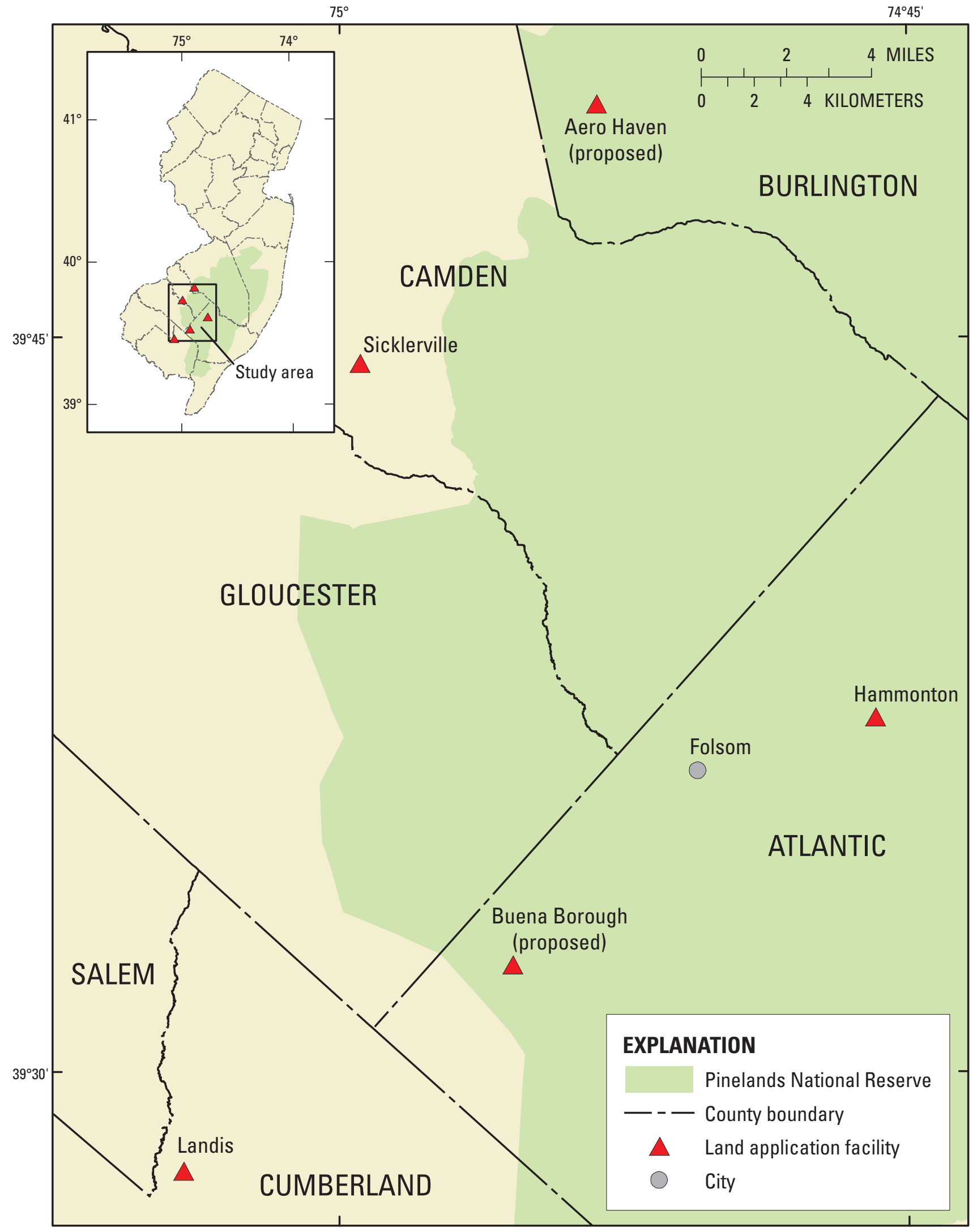

Base from U.S. Geological Survey 1:100,000 digital files

Figure 1. Locations of existing and proposed land application facilities within and near the Pinelands National Reserve, southern New Jersey. 


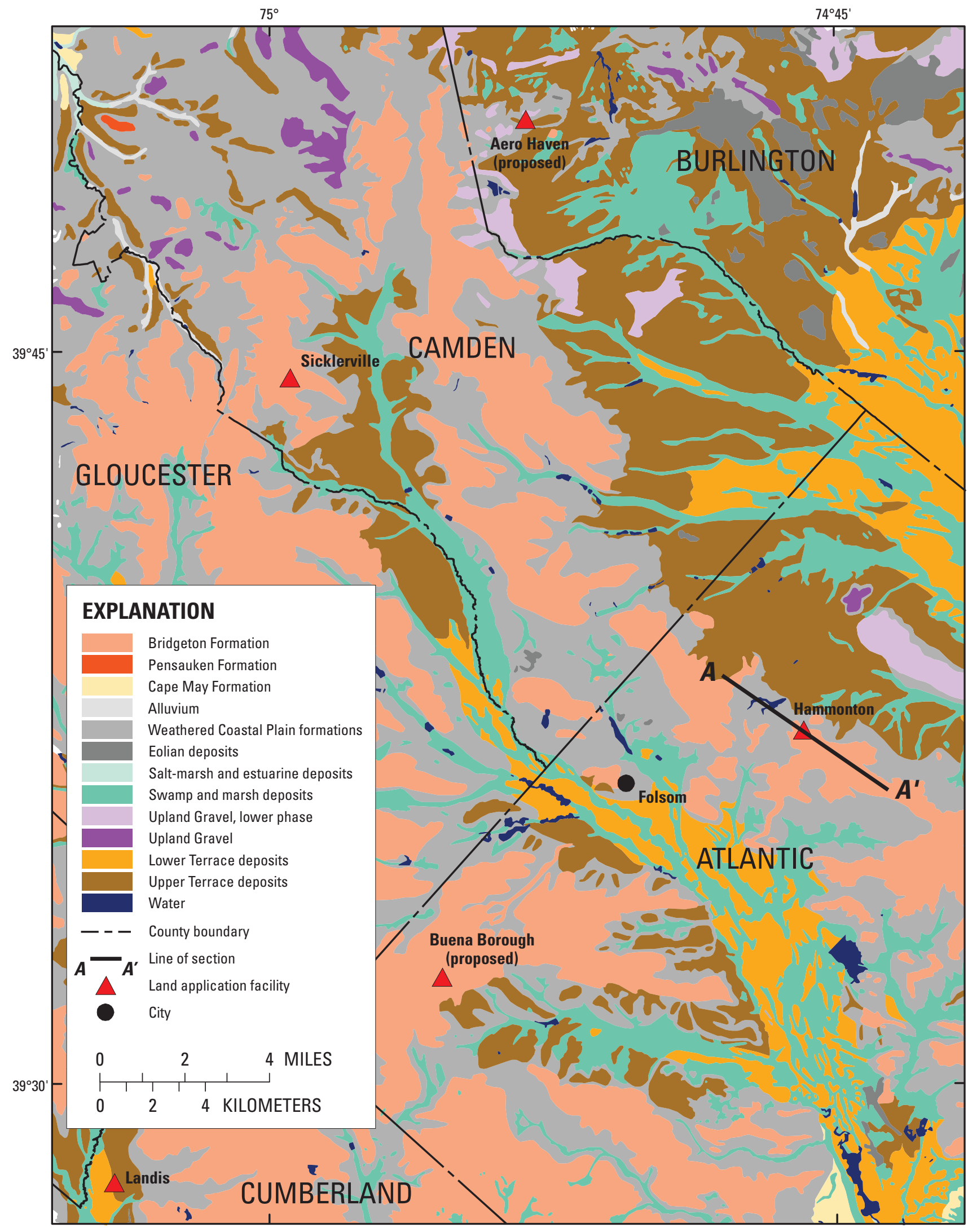

Base from U.S. Geological Survey 1:100,000 digital files

Geology from Pristas, 2004

Figure 2. Surficial geology underlying existing and proposed land application facilities within and near the Pinelands National Reserve, southern New Jersey. 


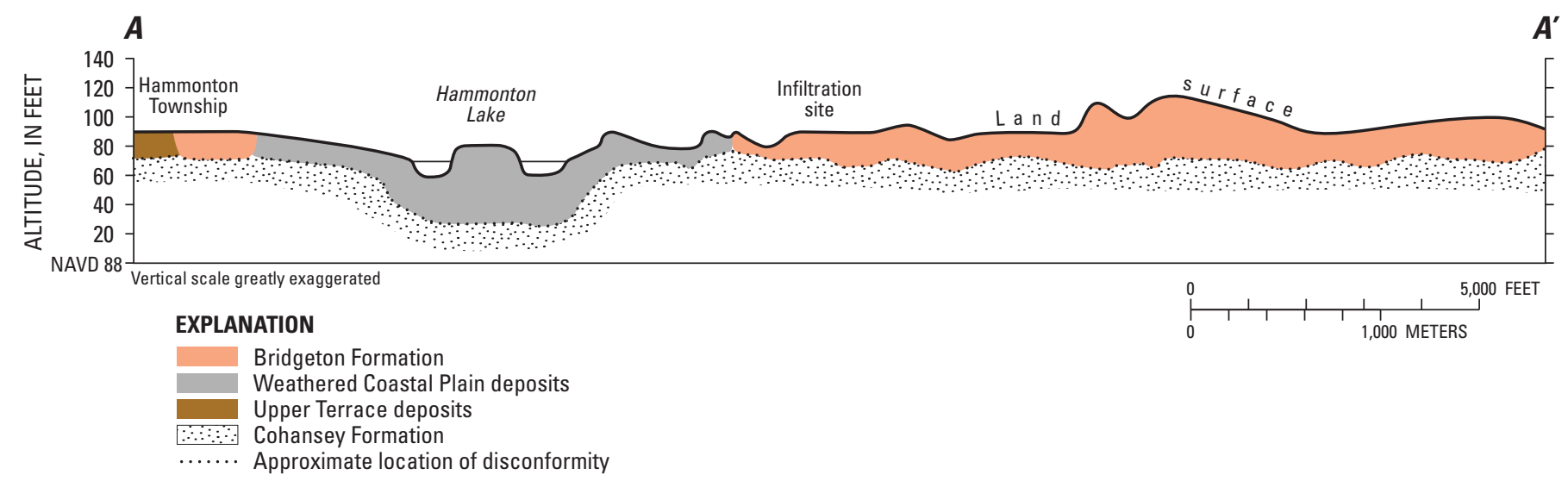

Figure 3. Geologic section $A-A^{\prime}$ showing surficial geology in the vicinity of the Hammonton Land Application Facility in the Pinelands National Reserve, southern New Jersey. (Line of section shown in fig. 2)

Aero Haven, the future Evesham Township LAF site, is underlain mostly by weathered Coastal Plain deposits (fig. 2). The southeastern and northern portions of the site are underlain by middle to late Pleistocene Upper Terrace deposits consisting of sand and pebble gravel with minor silt and cobble gravel (Newell and others, 2000). These deposits are as much as $20 \mathrm{ft}$ thick and form terraces with surfaces 20 to $50 \mathrm{ft}$ above the modern floodplain (Newell and others, 2000). The western part of the site is underlain by late Pliocene to middle Pleistocene Upland Gravel deposits consisting of up to $20 \mathrm{ft}$ of thick sand, clayey sand, and pebble gravel with some minor silt, which are erosional remnants capping lower uplands and interfluves (Newell and others, 2000). Underlying all of the surficial units in the study area is the Cohansey Formation, an unconsolidated, medium to coarse quartz sand with locally substantial clay beds, that were deposited in inner neritic to nearshore environments during a Miocene regression (Zapecza, 1989).

\section{Methods of Investigation}

The collection and analysis of sediment data, geophysical measurements, water-quality and associated quality-assurance data, water-level and flow data, and operational data, and the determination of altitudes and locations of wells and trenches at the Hammonton LAF are described below.

\section{Sediment Collection and Analysis}

Sediment samples were collected to determine the types and textures of geologic materials in the subsurface at the site. Sites were selected to provide areal coverage of the study area. The cores were collected immediately adjacent to the location where hydrologic profiling (described in the next section) and drive-point water-quality sampling were conducted.
Continuous cores were collected using a Geoprobe ${ }^{\circledR}$ direct push system (Geoprobe) and a Macro-Core ${ }^{\circledR}$ Soil Sampler (Macro-Core). The Macro-Core consists of a 52-in.-long, 2.2-in.-diameter solid barrel device that can be operated in open-tube or closed-point configuration (fig. 4) (Geoprobe Systems, 1998). Coring began at the land surface by driving a Macro-Core in the open-tube configuration $4 \mathrm{ft}$ into the subsurface and retrieving it with the Geoprobe. Subsequent cores were collected with the sampler in the closed-point configuration. In the closed-point configuration, a piston rod and stop pin hold a point into the cutting shoe, preventing collection of sediment that sloughs into the open hole from the wall of the boring. The sealed Macro-Core is driven to the top of the sampling interval, the stop pin and piston rod are removed, and the assembly is advanced to the bottom of the sampling interval with the Geoprobe (Geoprobe Systems, 1998). The point is later retrieved from the sampler with the liner and soil core (Geoprobe Systems, 1998). The cores are contained in 1.5-in.-diameter by 48-in.-long acrylic core liners and were obtained by driving the Macro-Core through sediment with the Geoprobe. By repeating this process, continuous cores are collected to the desired depth. The only gap in coring occurs when the recovered core is less than 48 in. long. This can occur when sediment is lost by falling through the cutting shoe into the open hole, if the core barrel is blocked (preventing the collection of core), or by compression of the sample. All losses of sediment are assumed to be from the bottom of the core (commonly referred to as "top justified"). Liners were capped immediately after core retrieval and stored in wax-impregnated boxes. The liners were opened in the laboratory with a specialized cutter to describe and sample the sediment cores.

\section{Geophysical Measurements}

Natural gamma-ray emissions and the hydraulic performance of the sediments were measured to supplement geologic data acquired through the collection and analysis of 


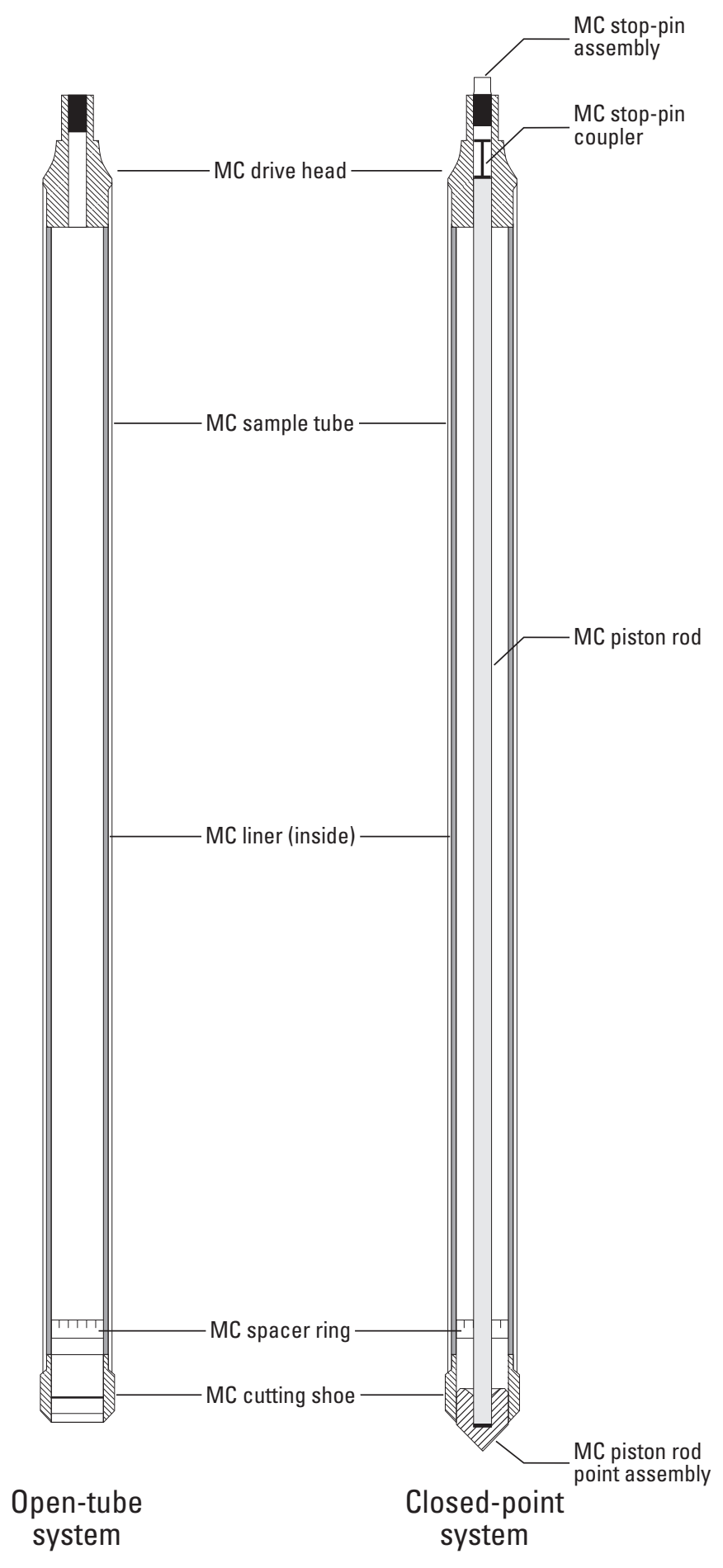

Figure 4. Open-tube and closed-point soil sampler configurations. (MC, Macro Core®)

continuous sediment cores. The data were used to construct a hydrogeologic framework for the site and to provide a means for comparing the hydraulic properties of sediments underlying the Hammonton LAF to those at other locations within the Pinelands. Natural gamma-ray logging was conducted on
31 cased boreholes or wells (fig. 5). A probe, which measures the rate of gamma-ray emission, is lowered into the borehole using a winch equipped with communication cables linking the probe to a surface computer. The computer controls the winch, triggers the probe, and records the resulting gammaemission rate. The well casing absorbs a constant portion of the radiation emitted by the formation it penetrates, and the probe measures the amount of natural radiation within the well (Fetter, 1994). This measurement technique works equally well above and below the water table and is not sensitive to the composition of the water in the well (Zapecza, 1989). Interpretation of this measurement exploits the higher concentrations of radioactive materials found in fine-grained strata. Feldspars and micas, which are the parent materials of the silts and clays in the region, contain small portions of the gammaemitting radioisotope potassium-40 (Keys and McCary, 1971). Therefore, high gamma-emission rates are attributed to low permeability, clay- and silt-rich strata, whereas low emission rates characterize high-permeability, sand-dominated strata. The use of gamma logging to detect low-permeability strata is limited in that low permeability can be caused by factors other than the presence of clay- and silt-rich strata (for example, iron-cemented sands or compressed sediments), and the gamma detector averages sediment properties within a sphere approximately $1 \mathrm{ft}$ in diameter. Therefore, this method may fail to identify some thin low-permeability layers or those that do not contain minerals that emit gamma radiation.

Gamma logs were collected at the Hammonton LAF from May 2006 to January 2007 with a Mount Sopris MGXII logger and a 2 PGA-100 tool (table 1). Natural gamma-ray emissions were measured every $0.164 \mathrm{ft}$. Logs were collected in the up and down directions. Depths of up and down logs were compared for quality assurance; logs with differences in depths of more than 2 percent were repeated.

Hydraulic testing was conducted at three sites (fig. 5) with a Hydraulic Profiling Tool (HPT) system manufactured by Geoprobe Systems (Salina, Kansas). As the HPT is driven into unconsolidated sediments by direct-drive at $0.79 \mathrm{in} / \mathrm{min}$, clean water is pumped through a screen on the side of the HPT probe at about $250 \mathrm{~mL} / \mathrm{min}$ and the resulting injection pressure is recorded. Relative hydraulic properties are determined by evaluation of injection pressure and flow rate; a formation with lower hydraulic conductivity would have a higher pressure response and a lower flow response than a more hydraulically conductive formation. The HPT system also measures soil electrical conductivity with an integrated Wenner array. High electrical conductivities are generally associated with fine-grained formations, although they can also be influenced by the chemistry of pore fluids (high ionic strengths, contaminants) and the mineralogy of the sediments. The electrical conductivity and pressure response of the system are calibrated and tested before and after each log. Additional operational and technical specifications for the HPT are detailed in the standard operating procedure (Geoprobe Systems, 2007). 


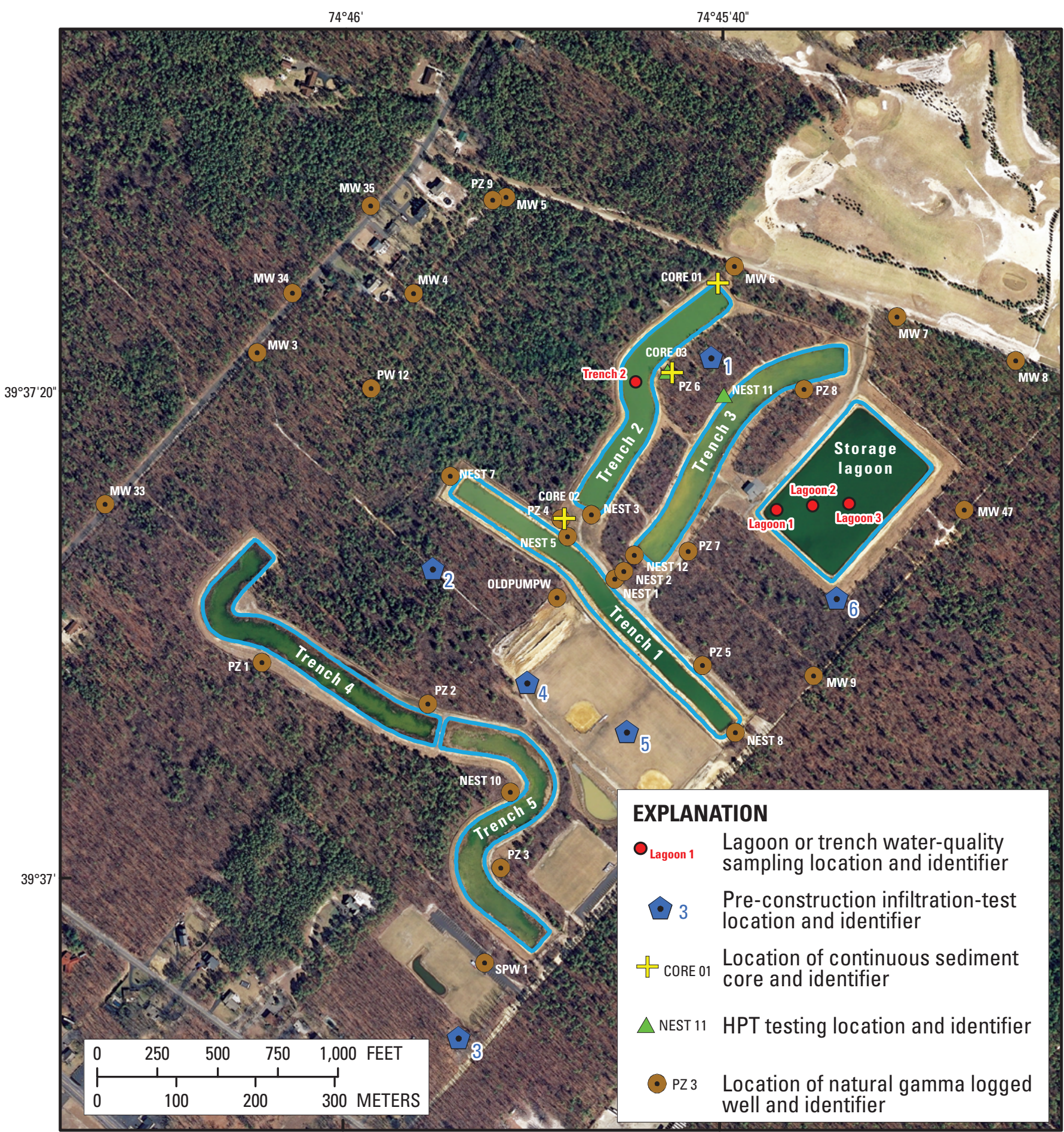

Orthophoto from New Jersey Office of Information Technology, Office of Geographic Information Systems, 2008

Figure 5. Locations of wells, lagoon and trench sampling sites, infiltration tests, continuous sediment cores, and Hydraulic Profile Tool (HPT) testing at the Hammonton Land Application Facility, southern New Jersey. 
Table 1. Selected well-construction information and date of natural gamma logging for monitoring wells and piezometers, Hammonton Land Application Facility, southern New Jersey.

[--, gamma log not obtained; NAVD 88, North American Vertical Datum of 1988]

\begin{tabular}{|c|c|c|c|c|c|c|}
\hline Local well name & Longitude & Latitude & $\begin{array}{c}\text { Altitude } \\
\text { (feet above NAVD 88) }\end{array}$ & $\begin{array}{l}\text { Total depth } \\
\text { (feet) }\end{array}$ & $\begin{array}{l}\text { Screen length } \\
\text { (feet) }\end{array}$ & $\begin{array}{c}\text { Date of } \\
\text { gamma log }\end{array}$ \\
\hline DP 01 & -74.454 & 39.373 & 91.00 & 36.85 & 2 & -- \\
\hline DP 03 & -74.454 & 39.372 & 90.00 & 35.07 & 2 & -- \\
\hline MW 3 & -74.768 & 39.623 & 92.65 & 47.38 & 10 & $7 / 19 / 2006$ \\
\hline MW 5 & -74.764 & 39.624 & 72.30 & 27.17 & 10 & $7 / 20 / 2006$ \\
\hline MW 6 & -74.761 & 39.624 & 96.38 & 47.38 & 10 & $5 / 31 / 2006$ \\
\hline MW 7 & -74.759 & 39.623 & 97.90 & 57.30 & 10 & $7 / 10 / 2006$ \\
\hline MW 8 & -74.757 & 39.623 & 85.98 & 46.97 & 10 & $7 / 10 / 2006$ \\
\hline MW 35 & -74.766 & 39.624 & 80.77 & 22.68 & 10 & $7 / 20 / 2006$ \\
\hline MW 47 & -74.758 & 39.621 & 82.54 & 24.29 & 10 & $7 / 13 / 2006$ \\
\hline NEST 1 MW C & -74.763 & 39.620 & 105.28 & 28.68 & 1 & $7 / 11 / 2006$ \\
\hline NEST 2 MW C & -74.763 & 39.620 & 101.57 & 23.62 & 1 & $7 / 11 / 2006$ \\
\hline NEST 3 MW C & -74.763 & 39.621 & 106.96 & 29.56 & 1 & $7 / 11 / 2006$ \\
\hline NEST 5 MW C & -74.763 & 39.621 & 106.30 & 28.43 & 1 & $7 / 11 / 2006$ \\
\hline NEST 7 MW C & -74.765 & 39.621 & 105.35 & 27.61 & 1 & $7 / 11 / 2006$ \\
\hline NEST 8 MW C & -74.761 & 39.618 & 105.61 & 26.96 & 1 & $7 / 11 / 2006$ \\
\hline OLDPUMPW & -74.764 & 39.620 & 108.77 & 92.02 & unknown & $7 / 19 / 2006$ \\
\hline PW 12 & -74.766 & 39.622 & 81.78 & 75.36 & 5 & $7 / 19 / 2006$ \\
\hline PZ 1 & -74.768 & 39.619 & 100.06 & 57.44 & 25 & $7 / 19 / 2006$ \\
\hline $\mathrm{PZ} 2$ & -74.765 & 39.619 & 106.02 & 53.89 & 25 & $7 / 13 / 2006$ \\
\hline PZ 3 & -74.764 & 39.617 & 106.34 & 57.28 & 25 & $7 / 13 / 2006$ \\
\hline PZ 4 & -74.763 & 39.621 & 104.22 & 55.61 & unknown & $7 / 21 / 2006$ \\
\hline PZ 5 & -74.761 & 39.619 & 102.00 & 57.00 & unknown & $7 / 13 / 2006$ \\
\hline PZ 6 & -74.762 & 39.622 & 106.31 & 59.35 & 20 & $7 / 11 / 2006$ \\
\hline PZ 7 & -74.762 & 39.620 & 96.74 & 50.22 & 25 & $7 / 11 / 2006$ \\
\hline PZ 8 & -74.760 & 39.622 & 101.14 & 57.78 & 25 & $7 / 10 / 2006$ \\
\hline PZ 9 & -74.764 & 39.624 & 73.10 & 24.14 & 25 & $5 / 31 / 2006$ \\
\hline
\end{tabular}




\section{Water-Quality Sampling}

Water-quality samples were collected to evaluate the potential role of dissolved constituents in physical or chemical processes that could impede infiltration. A secondary purpose was to identify tracers that could be used to differentiate infiltrated and natural water in the subsurface. Samples of treated effluent and groundwater were collected from November 2006 to May 2007 (table 2). (A complete list of analytes and method reporting limits (MRLs) is provided in appendixes 1 and 2). Samples collected from the Hammonton WWTP were composited over a 24-hour period to account for variations over time. Samples from the lagoons and trenches were composited spatially and with depth to account for possible layering or other differences.

Effluent samples collected from the Hammonton WWTP were collected using a composite sampler over a 24-hour period. The sampler was located downstream from the UVtreatment station and immediately prior to either discharge to the stream or pumping to the land application site. One grab sample of both pre- and post-UV-treated effluent was collected for analysis for wastewater indicator compounds to determine whether UV was effective at removing these compounds. All other chemical analyses of effluent were conducted on composite samples (table 2).

Within the storage lagoon, samples of treated effluent were collected from three locations on December 6, 2006, and May 3, 2007 (fig. 5). During both sampling events, a multiparameter water-quality meter was used to determine changes in $\mathrm{pH}$, temperature, specific conductance (SC), and dissolvedoxygen content (DO) with depth. Field staff noted that the lagoon was well mixed, as $\mathrm{pH}$, temperature, $\mathrm{SC}$, and $\mathrm{DO}$ did not vary with depth or, in the case of the December 6, 2006, sampling event, between sampling locations. Vertical composite samples were collected at each location using a weighted bottle sampler and were composited in an acid-washed, methanol-rinsed Teflon churn.

Samples of treated effluent were collected from trench 2 on December 5-7, 2006, and on May 3, 2007, using a tethered boat (figs. 5 and 6). Vertical composite samples were collected from the center of the trench at seven equally spaced locations using a weighted bottle sampler and were composited in an acid-washed, methanol-rinsed Teflon churn. On the morning of December 5, 2006, trench 2 had just been filled to capacity (approximately $6 \mathrm{ft}$ of treated wastewater). Trench 2 was sampled again on the morning of December 7, 2006, to determine whether sediment entrainment and agitation had affected water quality.

Groundwater samples were collected from selected monitoring wells, piezometers, and drive points. Locations of sampled wells are shown in figure 5 and construction information is given in table 1. Wells MW 5 and MW 8 were selected for sampling as they are located on the perimeter of the facility downgradient from the infiltration trenches. Wells PZ 4, PZ 5, and PZ 6 were selected for sampling because of their proximity to trenches 1 to 3 ; however, the screened interval for PZ 6 is $20 \mathrm{ft}$ long and the screen length for PZ 4 and PZ 5 is unknown. (Based on the construction of other piezometers, the screen lengths are likely 20 or $25 \mathrm{ft}$.) To obtain water samples from immediately below the water table immediately adjacent to the trenches, temporary drive-point (DP) wells DP-1, DP-2, and DP-3 were constructed using a Geoprobe ${ }^{\circledR}$ SP-15 groundwater sampling system. The screened opening was set as near to the water table as possible. After sampling was completed, the temporary wells were removed and sealed with grout. Temporary well DP-1 was located on the downgradient side of trench 2, whereas temporary wells DP-2 and DP-3 were colocated with PZ 4 and PZ 6, respectively. Well Nest 11 MW A was selected as it was the only well at the facility that clearly contained perched water. Wells were pumped with either peristaltic or submersible pumps with acid-washed, methanol-rinsed tubing. Temporary wells were sampled using $1 / 4$-in. acid-washed, methanol-rinsed Teflon tubing and check valves and pumped using a tubing check valve. At least three casing volumes of water were removed from wells prior to sampling, and field-measured properties $(\mathrm{pH}, \mathrm{SC}$, temperature, and turbidity) were monitored before sampling to ensure stable values prior to collecting water-quality samples (Wilde and Radtke, 1998). Surging caused by sampling with check valves can increase the DO in the samples; therefore, DO was neither used as part of the stability criteria nor included in subsequent water-quality analyses. Well Nest $11 \mathrm{MW}$ A is a piezometer adjacent to trench 3 that was installed by Pennoni Associates as part of a network of 12 piezometer nests to detect lateral flow between the trenches (Seth Gladstone, Pennoni Associates, oral commun., 2008).

Treated effluent and groundwater samples were analyzed for major ions, trace elements, nutrients, total suspended sediment (residue), total and dissolved organic carbon, and, in selected samples, wastewater indicator compounds (examples of which include selected fragrances, surfactants, flame retardants, plasticizers, and sterols) at the USGS National Water Quality Laboratory, Denver, Colorado (NWQL) (app. 1 and 2). Table 2 lists the NWQL analytical schedules (groups of laboratory codes to be measured) performed on samples from each location at the facility. Constituent concentrations that are less than the MRL are reported as estimates. Concentrations less than the MRL are considered detections because peaks on the chromatograph can be reliably measured; however, they are estimated because they either are beyond the calibration range, or cannot be reliably measured because of other analytical limitations (Childress and others, 1999).

\section{Quality Assurance}

Quality assurance included collection of two sequential replicate groundwater samples and three equipment blank samples (two from the equipment used to sample treated 


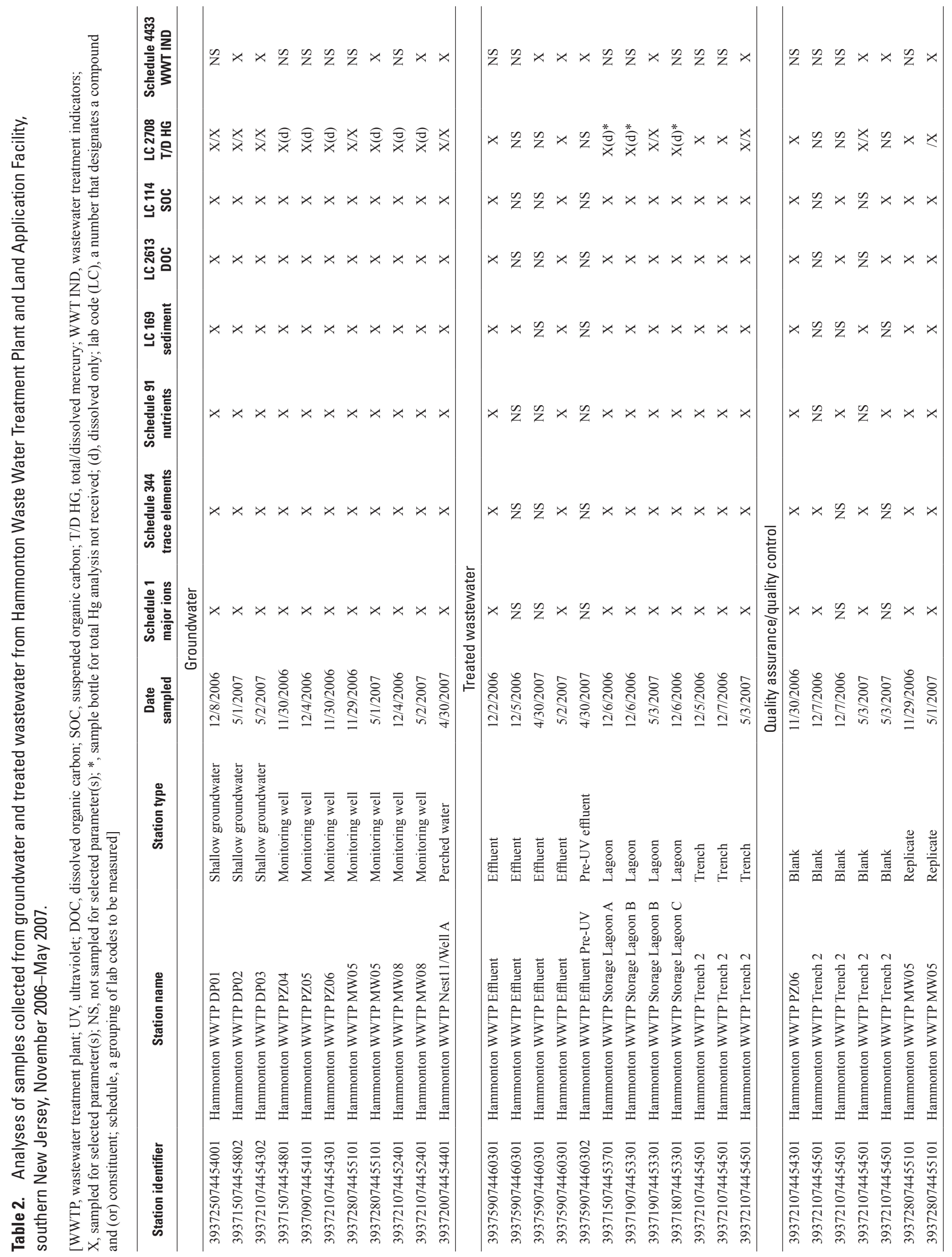




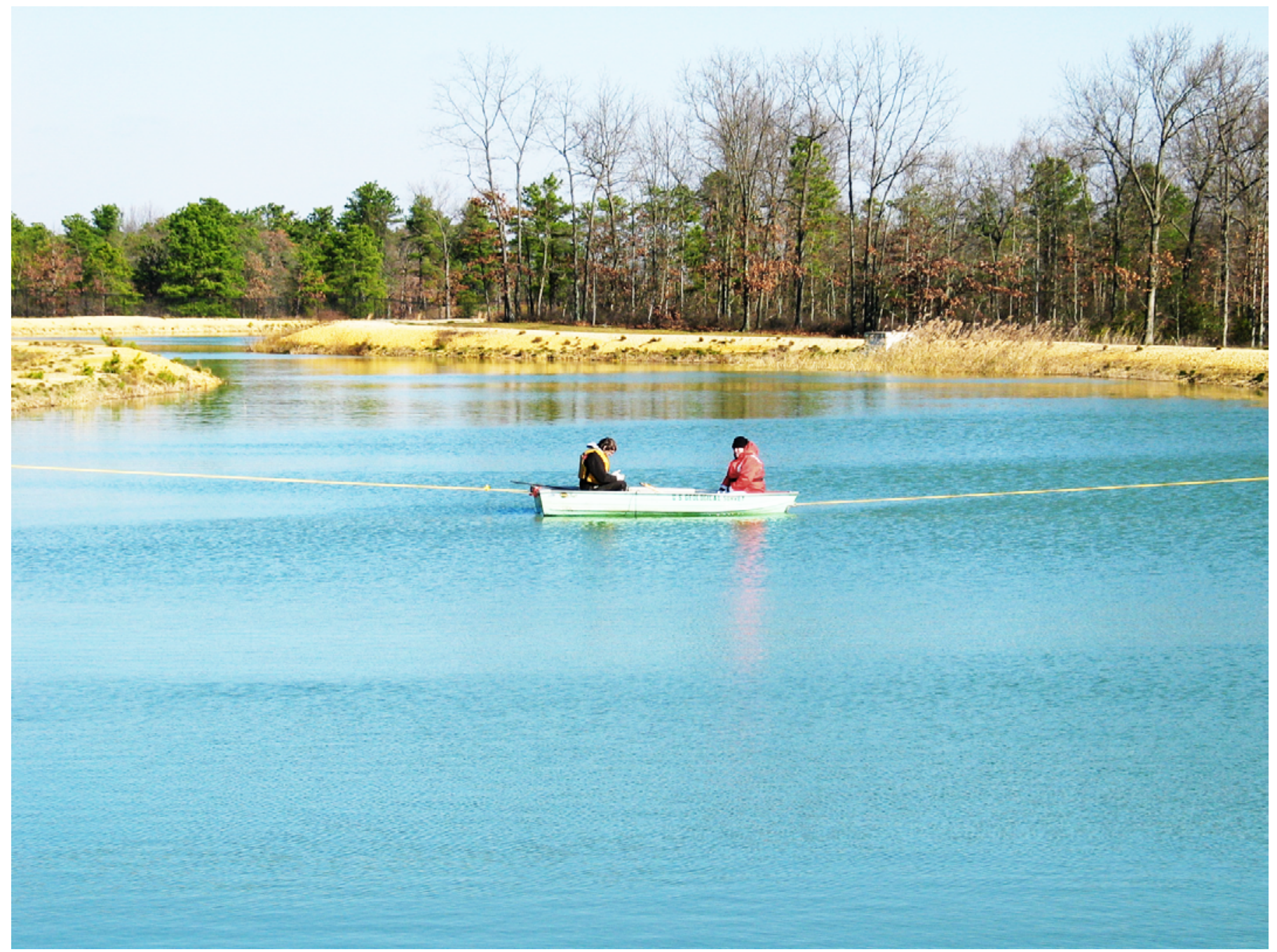

Figure 6. Water-quality sampling in trench 2, Hammonton Land Application Facility, southern New Jersey.

effluent in the trenches and one from the monitoring wells) (tables 2 and 3a). Comparisons of analysis results for majorion, trace-element, nutrient, and organic-carbon blank and replicate samples were satisfactory ( \pm 25 percent) with the exception of iron replicate analyses. Laboratory verification of the analyses in question was requested and the results were confirmed. The cause of the difference between the analyses of the sequential replicate samples for iron is unknown. Results of analyses of all samples for iron are reported but were not relied upon for interpretation of water-quality results. Comparisons of the analysis results for waste-indicatorcompound field blank and replicate samples were satisfactory, as there were no detections in the field blank or the paired environmental and replicate analyses (table $3 b$ ). Precision of selected analyses was calculated based on the results of analyses of blind samples by the USGS Branch of Quality Systems as part of its inorganic and organic blind sample programs (app. 3).

\section{Water-Level and Flow Measurement}

The operational data from the Hammonton LAF were stored as a single Excel file for each day for which data were available. This resulted in 1,560 files for April 2002 to September 2007. Files were arranged in monthly folders nested within annual folders. Each Excel file was named for the date 


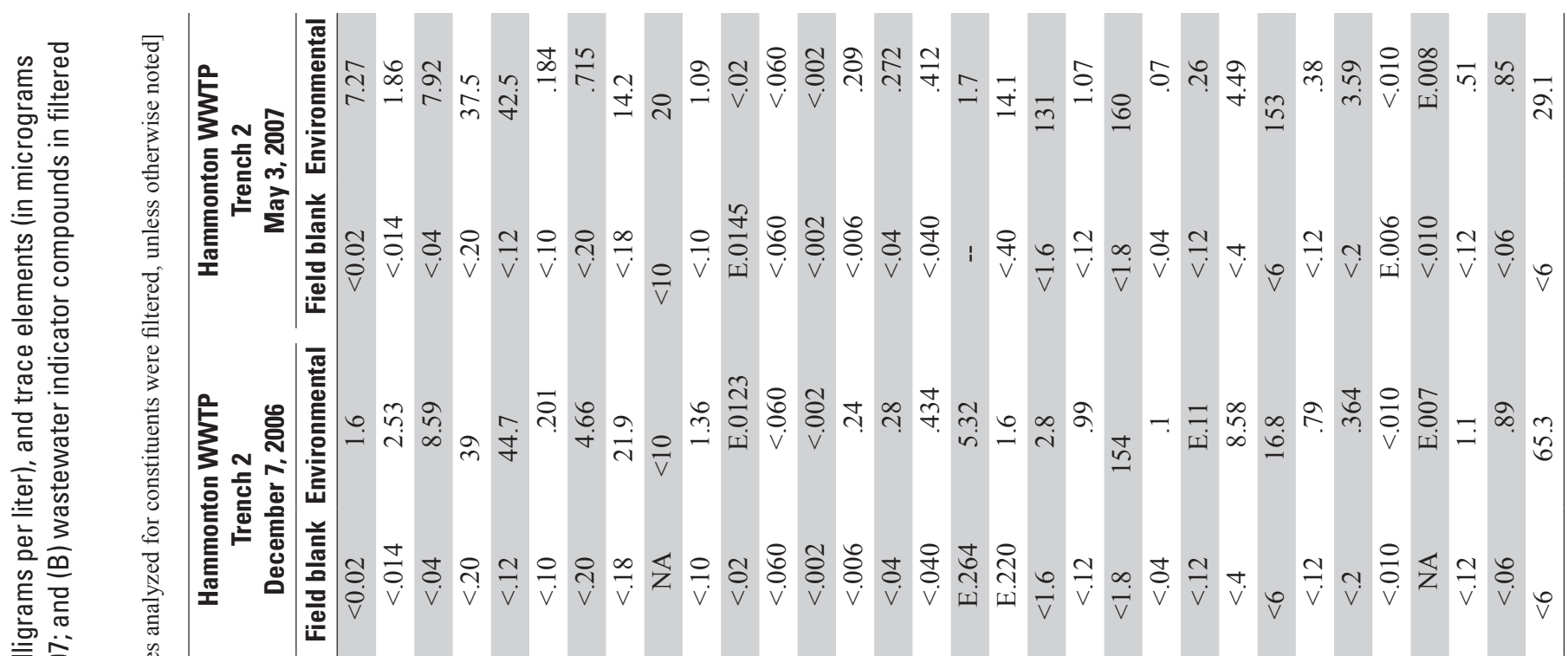

产

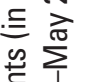

흘

츨

童

흥

空离宫

흔

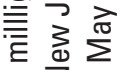

垴

它

흥 호응

ब

这演

힌

등

흥. 든

要

言 등.

잉

突

要

흥 뚱

究

西

政

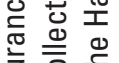

言

象

흥

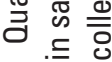

m.

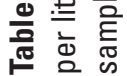
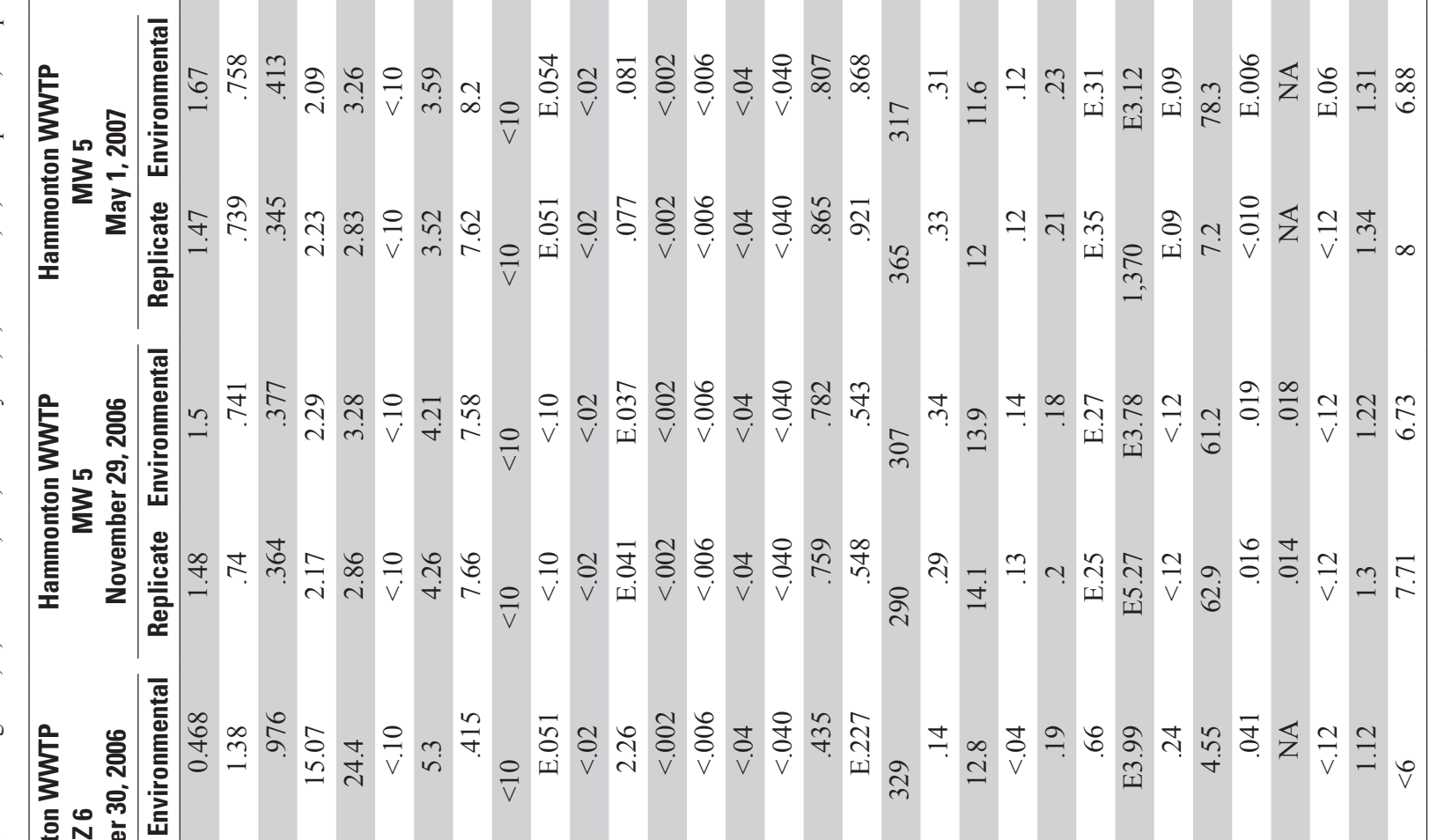
Table 3. Quality-assurance and associated environmental data for (A) major ions (in milligrams per liter), nutrients (in milligrams per liter), and trace elements (in micrograms per liter) in samples collected at the Hammonton Land Application Facility, southern New Jersey, November 2006-May 2007; and (B) wastewater indicator compounds in filtered samples collected at the Hammonton Land Application Facility, southern New Jersey, May 2007.—Continued

[WWTP, wastewater treatment plant; MW, monitoring well; E, estimated; $<$, less than]

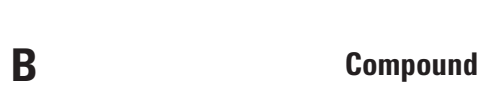

\section{Hammonton WWTP Trench 2 \\ May 3, 2007}

\begin{tabular}{|c|c|c|c|c|}
\hline & Environmental & Field blank & Environmental & Replicate \\
\hline 1-Methylnaphthalene & $<0.2$ & $<0.2$ & $<0.2$ & $<0.2$ \\
\hline 2,6-Dimethylnaphthalene & $<.2$ & $<.2$ & $<.2$ & $<.2$ \\
\hline 2-Methylnaphthalene & $<.2$ & $<.2$ & $<.2$ & $<.2$ \\
\hline 3,4-Dichlorophenyl isocyanate & $<2$ & $<2$ & $<2$ & $<2$ \\
\hline 3-beta-Coprostanol & $<.8$ & $<.8$ & $<.8$ & $<.8$ \\
\hline 3-Methyl-1H-indole (skatol) & $<.2$ & $<.2$ & $<.2$ & $<.2$ \\
\hline 3-tert-Butyl-4-hydroxyanisole & $<.2$ & $<.2$ & $<.2$ & $<.2$ \\
\hline 4-Cumylphenol & $<.2$ & $<.2$ & $<.2$ & $<.2$ \\
\hline 4-n-Octylphenol & $<.2$ & $<.2$ & $<.2$ & $<.2$ \\
\hline 4-Nonylphenol & $<1.6$ & $<1.6$ & $<1.6$ & $<1.6$ \\
\hline 4-tert-Octylphenol & $<.2$ & $<.2$ & $<.2$ & $<.2$ \\
\hline 5-Methyl-1H-benzotriazole & $<1.6$ & $<1.6$ & $<1.6$ & $<1.6$ \\
\hline Acetophenone & $<.2$ & $<.2$ & $<.2$ & $<.2$ \\
\hline $\mathrm{AHTN}^{1}$ & $<.2$ & $<.2$ & $<.2$ & $<.2$ \\
\hline Anthracene & $<.2$ & $<.2$ & $<.2$ & $<.2$ \\
\hline 9,10-Anthraquinone & $<.2$ & $<.2$ & $<.2$ & $<.2$ \\
\hline Atrazine & $<.2$ & $<.2$ & $<.2$ & $<.2$ \\
\hline BDE congener 47 & $<.2$ & $<.2$ & $<.2$ & $<.2$ \\
\hline Benzo[a]pyrene & $<.2$ & $<.2$ & $<.2$ & $<.2$ \\
\hline Benzophenone & $<.2$ & $<.2$ & $<.2$ & $<.2$ \\
\hline beta-Sitosterol & E.920 & $<.8$ & $<1.6$ & $<1.6$ \\
\hline beta-Stigmastanol & $<.8$ & $<.8$ & $<.8$ & $<.8$ \\
\hline Bis(2-ethylhexyl) phthalate & $<2$ & $<2$ & $<2$ & $<2$ \\
\hline Bisphenol A & $<.4$ & $<.4$ & $<.4$ & $<.4$ \\
\hline Bromacil & $<.2$ & $<.2$ & $<.2$ & $<.2$ \\
\hline Caffeine & $<.2$ & $<.2$ & $<.2$ & $<.2$ \\
\hline Camphor & $<.2$ & $<.2$ & $<.2$ & $<.2$ \\
\hline Carbaryl & $<.2$ & $<.2$ & $<.2$ & $<.2$ \\
\hline Carbazole & $<.2$ & $<.2$ & $<.2$ & $<.2$ \\
\hline Chlorpyrifos & $<.2$ & $<.2$ & $<.2$ & $<.2$ \\
\hline Cholesterol & E2.78 & $<.8$ & $<.8$ & $<.8$ \\
\hline Cotinine & $<.8$ & $<.8$ & $<.8$ & $<.8$ \\
\hline DEET & $<.2$ & $<.2$ & $<.2$ & $<.2$ \\
\hline Diazinon & $<.2$ & $<.2$ & $<.2$ & $<.2$ \\
\hline Dichlorvos & $<.2$ & $<.2$ & $<.2$ & $<.2$ \\
\hline
\end{tabular}


Table 3. Quality-assurance and associated environmental data for (A) major ions (in milligrams per liter), nutrients (in milligrams per liter), and trace elements (in micrograms per liter) in samples collected at the Hammonton Land Application Facility, southern New Jersey, November 2006-May 2007; and (B) wastewater indicator compounds in filtered samples collected at the Hammonton Land Application Facility, southern New Jersey, May 2007.—Continued

[WWTP, wastewater treatment plant; MW, monitoring well; E, estimated; <, less than]

\begin{tabular}{|c|c|c|c|c|c|}
\hline \multirow[t]{2}{*}{$\mathbf{B}$} & \multirow{2}{*}{ Compound } & \multicolumn{2}{|c|}{$\begin{array}{c}\text { Hammonton WWTP Trench } 2 \\
\text { May 3, } 2007\end{array}$} & \multicolumn{2}{|c|}{$\begin{array}{c}\text { Hammonton WWTP MW } 5 \\
\text { May 1, } 2007\end{array}$} \\
\hline & & Environmental & Field blank & Environmental & Replicate \\
\hline & Diethoxynonylphenol (all isomers) (Total NPEO2) & $<3.2$ & $<3.2$ & $<3.2$ & $<3.2$ \\
\hline & Diethoxyoctylphenol (OPEO2) & $<.32$ & $<.32$ & $<.32$ & $<.32$ \\
\hline & Diethyl phthalate (Total NPEO2) & .261 & $<.2$ & $<.2$ & $<.2$ \\
\hline & D-Limonene (OPEO2) & $<.2$ & $<.2$ & $<.2$ & $<.2$ \\
\hline & Ethoxynonylphenol (all isomers) (NPEO1) & $<2$ & $<2$ & $<2$ & $<2$ \\
\hline & Ethoxyoctylphenol (OPEO1) & $<1$ & $<1$ & $<1$ & $<1$ \\
\hline & Fluoranthene & $<.2$ & $<.2$ & $<.2$ & $<.2$ \\
\hline & $\mathrm{HHCB}^{3}$ & $<.2$ & $<.2$ & $<.2$ & $<.2$ \\
\hline & Indole & $<.2$ & $<.2$ & $<.2$ & $<.2$ \\
\hline & Isoborneol & $<.2$ & $<.2$ & $<.2$ & $<.2$ \\
\hline & Isophorone & $<.2$ & $<.2$ & $<.2$ & $<.2$ \\
\hline & Isoquinoline & $<.2$ & $<.2$ & $<.2$ & $<.2$ \\
\hline & Menthol & $<.2$ & $<.2$ & $<.2$ & $<.2$ \\
\hline & Metalaxyl & $<.2$ & $<.2$ & $<.2$ & $<.2$ \\
\hline & Methyl salicylate & $<.2$ & $<.2$ & $<.2$ & $<.2$ \\
\hline & Metolachlor & $<.2$ & $<.2$ & $<.2$ & $<.2$ \\
\hline & p-Cresol & $<.2$ & $<.2$ & $<.2$ & $<.2$ \\
\hline & Pentachlorophenol & $<.8$ & $<.8$ & $<.8$ & $<.8$ \\
\hline & Phenanthrene & $<.2$ & $<.2$ & $<.2$ & $<.2$ \\
\hline & Phenol & $<.2$ & $<.2$ & $<.2$ & $<.2$ \\
\hline & Prometon & $<.2$ & $<.2$ & $<.2$ & $<.2$ \\
\hline & Pyrene & $<.2$ & $<.2$ & $<.2$ & $<.2$ \\
\hline & Tributyl phosphate & $<.2$ & $<.2$ & $<.2$ & $<.2$ \\
\hline & Triclosan & $<.2$ & $<.2$ & $<.2$ & $<.2$ \\
\hline & Triethyl citrate & $<.2$ & $<.2$ & $<.2$ & $<.2$ \\
\hline & Triphenyl phosphate & $<.2$ & $<.2$ & $<.2$ & $<.2$ \\
\hline & Tris(2-butoxyethyl) phosphate & $<.2$ & $<.2$ & $<.2$ & $<.2$ \\
\hline & Tris(2-chloroethyl) phosphate & E. 120 & $<.2$ & $<.2$ & $<.2$ \\
\hline & Tris(dichloroisopropyl) phosphate & $<.2$ & $<.2$ & $<.2$ & $<.2$ \\
\hline & 1,4-Dichlorobenzene & $<.2$ & $<.2$ & $<.2$ & $<.2$ \\
\hline & Isopropylbenzene & $<.2$ & $<.2$ & $<.2$ & $<.2$ \\
\hline & Naphthalene & $<.2$ & $<.2$ & $<.2$ & $<.2$ \\
\hline & Tetrachloroethene & $<.4$ & $<.4$ & $<.4$ & $<.4$ \\
\hline & Tribromomethane & $<.2$ & $<.2$ & $<.2$ & $<.2$ \\
\hline
\end{tabular}

${ }^{1}$ 7-Acetyl-1,1,3,4,4,6-hexamethyl tetra hydro naphthalene

${ }^{2} \mathrm{~N}, \mathrm{~N}-$ Diethyl toluamide

${ }^{3} 1,3,4,6,7,8$-Hexahydro 4,6,6,7,8,8-hexamethyl cyclopenta-4-2-benzopyran 
of the 24-hour data period, and each file had a single worksheet with a cell containing a date-formula and two hourly data grids arranged in different ways. The data grids contained the 24 hourly values for pumping into individual trenches from the lagoon and the water levels in the lagoon and trenches. An application was written in Microsoft (MS) Access to process the files whereby the user selects a starting folder and the program parses through the subfolders to gather the names of the daily Excel files, and then, one by one, extracts the data from each file into a single table within a MS Access database. Data-quality issues were identified and resolved with the staff of the Hammonton WWTP; these included bad dates in the filename or on the worksheet, duplicate data, incomplete hourly records, and data gaps (missing days).

The data were processed into two tables. One was structured such that each row represented a single hour and each of the five pumping and six water-level values were arranged in side-by-side fields. In the second structure, the data were arranged with a single value for each row-either (1) a lagoon or trench water-level value or (2) a lagoon-to-trench pumping value. After the hourly data were loaded, additional processing was conducted to calculate the difference in water levels from the previous hourly values and tag a record if it appeared to be at the start or end of an "infiltration episode" (that period of time when a trench is receiving no water from the lagoon). The entire procedure for gathering and arranging the Excel data into the Access tables was implemented through a single form in MS Access to do the processing automatically and with minimal user interaction.

\section{Analysis of Operational Data}

Hammonton LAF operational records for April 2002 to September 2007 were compiled and analyzed to estimate infiltration rates and determine whether they had changed over time. Gage height (inches above the trench floor) in the trenches and the storage lagoon and the flow rate (gallons per minute) of water transferred from the storage lagoon to the various trenches are recorded hourly by an automated system. To verify that operational records were complete, the total volume recorded in 1,560 days of operation was compared to the volume of treated wastewater known to have been transferred to Hammonton LAF. The summed hourly flow data account for 99.2 percent of the reported flow; therefore, we are confident that the flow records are complete and confirm that the primary source of water loss on the facility is infiltration from the trenches. If evaporation or leakage (either from the lagoon or from within the plumbing) was significant, the difference between reported discharge from the WWTP to the storage lagoon and transfer from the storage lagoon to the trenches would be greater.

Operational records and estimated trench dimensions were used to calculate infiltration rates for trenches 1 to 3 . Infiltration events were identified by examining operational records for loading events (the filling of a trench) followed by a period of declining stage in the trench. Events with missing records that would affect the calculated infiltration rate are not included in this analysis. Trench shapes were assumed to be equilateral trapezoids and their respective volumes were estimated by multiplying the average width by the length. The volume of treated wastewater transferred into the trenches is known; volumes were also calculated by multiplying the recorded stage by the estimated trench areas. Infiltration rates were calculated for two distinct portions of an event: during trench filling (initial infiltration rate) and after filling was complete (resting infiltration rate). When trenches are filling, the volume of treated wastewater entering each trench is known (based on highly accurate hourly pumping records). The initial infiltration volume $\left(V_{i}\right.$, cubic feet) is

$$
V_{i}=V_{p}-\left(h_{2} A_{2}-h_{1} A_{1}\right)
$$

where $V_{p}$ is the volume of treated wastewater pumped during the loading cycle (cubic feet); $h_{1}$ and $h_{2}$ are the gage heights observed prior to and at the end of the filling of the trench, respectively; and $A_{1}$ and $A_{2}$ are the wetted cross-sectional area of the trench prior to and at the end of the filling of the trench, respectively. The wetted cross-sectional areas $(A$, square feet) are calculated as follows:

$$
A=L(b+3 h)
$$

where $L$ is the length of the trench (feet), $b$ is the width of the base of the trench (feet), and $h$ is the gage height in the trench (feet). In this calculation, it is assumed that the trench is an equilateral trapezoid with a 3:1 sidewall slope and that infiltration occurs through the walls and floor of the trench. The resting infiltration volume $\left(V_{r}\right.$, cubic feet) is

$$
V_{r}=\left(h_{2} A_{2}-h_{3} A_{3}\right),
$$

where $A_{3}$ (square feet) and $h_{3}$ (feet) are the wetted crosssectional area and gage height at the end of the infiltration event. Infiltration rates $(I)$ were calculated as follows:

$$
I=\frac{V}{A D},
$$

where $V$ is the volume of infiltrated water and $D$ is the duration (hours) of the infiltration event. Although most calculated infiltration volumes indicate that water was lost from the trench, 7 of the 41 infiltration events evaluated (at least 2 from each trench) indicate that the trench gained more water than expected during loading. The timing of these events was compared to precipitation records from a rain gage operated by the USGS approximately $5 \mathrm{mi}$ southwest of the Hammonton LAF in Folsom, NJ. Loading cycles coincided with rainstorms totaling more than $0.1 \mathrm{in}$. of rain for only two events. The most likely explanation for the remaining negative infiltration rates is the lateral flow of perched water. 


\section{Determination of Altitude and Location}

The USGS conducted an altitude survey from November 21,2006 , to December 20, 2006, to verify the altitude of the land surface adjacent to, and measuring points of, monitoring wells and to measure the altitude of land surface along cross sections of trench 1. Altitudes were measured using a Nikon AS-2C autolevel and a Chicago-style survey rod according to USGS standard methods (Kennedy, 1990). Altitudes were transferred to wells from National Geodetic Survey marker number JU4373 (39³6'50.01734’”N, 07445'10.31124”W). Land-surface altitudes and the altitude of the lip of the outer protective casing (measuring point) were determined for each well surveyed. Locations of wells and cross sections were determined using a consumer-grade hand-held global positioning system (GPS) unit ( $\pm 6.56 \mathrm{ft}$ horizontal accuracy).

\section{Physical, Chemical, and Hydrologic Factors}

Results of the hydrogeologic framework, water-quality data, operational data and conditions of the infiltration trenches, and trench wall collapses, at the Hammonton Waste Water Treatment Plant and Land Application Facility are discussed below. Additionally, a comparison to other Pinelands Land Application Facilities is discussed.

\section{Hydrogeologic Framework}

A hydrogeologic framework for the Hammonton LAF was created based on the results of geophysical logging, HPT testing, and examination of sediment cores. Gamma logs were collected from 31 existing monitoring wells from May 2006 through January 2007 (fig. 5). Continuous sediment cores and HPT testing were used to verify the stratigraphy determined from the gamma logs. Nine strata were identified by examination of sediment cores and by correlating HPT and naturalgamma-radiation logs within the unsaturated zone: four distinct hydraulically restrictive strata and five non-restrictive strata. These strata are typified in logs and cores collected adjacent to PZ 6 (fig. 7). The contact between the Cohansey and Bridgeton Formations is at $74.74 \mathrm{ft}$ and is identified by the transition from the variable gamma response of the overlying Bridgeton Formation and weathered Coastal Plain deposits to the characteristically low (typically less than 25 counts per second) natural-gamma radiation of the Cohansey Formation. The Cohansey Formation is the oldest unit observed at the Hammonton LAF. HPT testing of this unit shows injection pressures typically less than $40 \mathrm{lb} / \mathrm{in}^{2}$ (psi) and flow rates greater than $150 \mathrm{~mL} / \mathrm{min}$, indicating that the stratum is hydraulically non-restrictive.
Eight strata $(\mathrm{A}-\mathrm{H})$ within the overlying Bridgeton Formation were identified and correlated throughout the Hammonton LAF (fig. 7). The oldest stratum (stratum A) is $2.65 \mathrm{ft}$ thick and extends from 75.06 to $77.71 \mathrm{ft}$ above NAVD 88. HPT testing shows pressures greater than 40 psi and flow rates as low as $0 \mathrm{~mL} / \mathrm{min}$, indicating that stratum $\mathrm{A}$ is hydraulically restrictive. The sediment within stratum A is characterized by very fine to coarse, ferric iron oxide-stained sands (Hammonton LAF core 03, app. 4). As the coring process can disaggregate poorly cemented sediments, the presence of iron oxide-stained grains indicates that this stratum may be cemented. Ferric iron concretions are present as a result of repeated cycles of water saturation and desaturation that cause microbial reduction and oxidation of iron and, after repeated wet and dry cycles, can cause impermeable iron stones to form (Soil Survey Division Staff, 1993). The proximity of seasonal high water-table altitudes measured at PZ 6 from January 2003 to December 2007 to the base of stratum A indicate that modern periodic watertable fluctuations may be the source of the cements.

Stratum B is $3.8 \mathrm{ft}$ thick and extends from 77.71 to $81.51 \mathrm{ft}$ above NAVD 88 (fig. 7). This stratum is characterized by slightly silty fine sand, poorly sorted medium sand, and silty fine sands (Hammonton LAF core 03, app. 4). HPT testing shows pressures less than 40 psi and flow rates generally greater than $250 \mathrm{~mL} / \mathrm{min}$. Natural-gamma-radiation measurements are near background levels. Sediment descriptions, HPT testing, and natural-gamma-radiation logging all indicate that stratum B is not hydraulically restrictive.

Stratum C is $3.3 \mathrm{ft}$ thick and extends from 81.51 to $84.81 \mathrm{ft}$ above NAVD 88 (fig. 7). The upper $1.25 \mathrm{ft}$ of this stratum is characterized by interbedded fine sand and massive clay and slightly silty fine sand (Hammonton LAF core 03, app. 4). Sediment from the lowermost $1 \mathrm{ft}$ of stratum $\mathrm{C}$ was not recovered during coring. HPT testing shows pressures greater than $40 \mathrm{psi}$ and flow rates as low as $79 \mathrm{~mL} / \mathrm{min}$. Naturalgamma-radiation measurements are generally elevated above background levels in this stratum. Sediment descriptions and results of HPT testing and natural-gamma-radiation logging all indicate that stratum $\mathrm{C}$ is hydraulically restrictive.

Stratum D is $4.77 \mathrm{ft}$ thick and extends from 84.81 to $89.28 \mathrm{ft}$ above NAVD 88 (fig. 7). This stratum is characterized by silty and clayey fine sands except for a sandy clay extending from 87.81 to $89.28 \mathrm{ft}$ (Hammonton LAF core 03, app. 4). With the exception of the sandy clay, results of HPT testing show pressures less than 40 psi and flow rates generally greater than $250 \mathrm{~mL} / \mathrm{min}$. Natural-gamma-radiation measurements are near background levels. Sediment descriptions and results of HPT testing and natural-gamma-radiation logging all indicate that stratum D is not hydraulically restrictive. HPT testing and sediment descriptions indicate that the sandy clay within this unit is hydraulically restrictive, but as it is not characterized by elevated natural-gamma radiation, it is not possible to map this bed. 


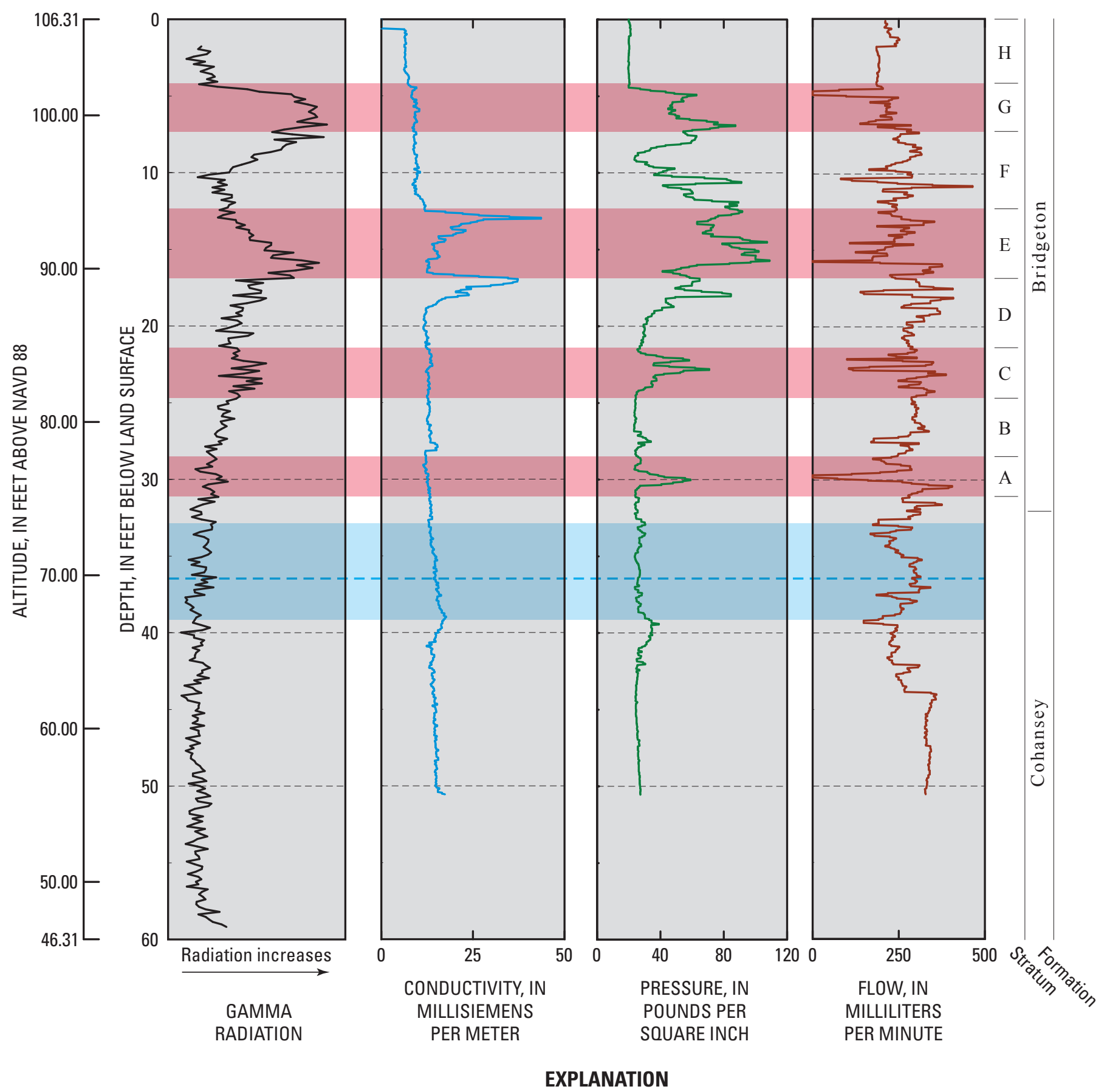

Hydraulically restrictive zone

Range of monthly water-table altitudes (January 2003-December 2007)

Mean water-table altitude (January 2003-December 2007)

Figure 7. Geophysical logs of piezometer 6, Hammonton Land Application Facility, southern New Jersey. 
Stratum E is $4.59 \mathrm{ft}$ thick and extends from 89.28 to $93.87 \mathrm{ft}$ above NAVD 88 (fig. 7). This stratum is characterized by silty sands and sandy clays (Hammonton LAF core 03, app. 4). Results of HPT testing show pressures greater than 40 psi and flow rates as low as $0 \mathrm{~mL} / \mathrm{min}$. Natural-gamma-radiation measurements are generally elevated above background levels in this stratum. Sediment descriptions and results of HPT testing and natural-gamma-radiation logging all indicate that stratum $\mathrm{E}$ is hydraulically restrictive.

Stratum F is $5.09 \mathrm{ft}$ thick and extends from 93.87 to $98.96 \mathrm{ft}$ above NAVD 88 (fig. 7). This stratum is characterized by clean to slightly silty fine sands except for a silty to very silty fine sand extending from 95.41 to $97.21 \mathrm{ft}$ (Hammonton LAF core 03, app. 4). Results of HPT testing show flow rates generally greater than $250 \mathrm{~mL} / \mathrm{min}$. Natural-gamma-radiation measurements are near background levels. Sediment descriptions and results of HPT testing and natural-gamma-radiation logging all indicate that stratum $\mathrm{F}$ is not hydraulically restrictive. HPT testing and sediment descriptions indicate that the silty to very silty fine sand within this unit is hydraulically restrictive, but as it is not characterized by elevated naturalgamma radiation, it is not possible to map this bed.

Stratum G is $3.12 \mathrm{ft}$ thick and extends from 98.96 to $102.08 \mathrm{ft}$ above NAVD 88 (fig. 7). This stratum is characterized by clean to very silty fine sand (Hammonton LAF core 03 , app. 4). Results of HPT testing show pressures greater than $40 \mathrm{psi}$ and flow rates as low as $0 \mathrm{~mL} / \mathrm{min}$. Naturalgamma-radiation measurements are generally elevated above background levels in this stratum. Results of HPT testing and natural-gamma-radiation logging indicate that stratum $G$ is hydraulically restrictive. Although sediment descriptions indicate fine sands throughout this section, compaction and the presence of various amounts of silt have reduced the hydraulic conductivity of this stratum relative to that of an uncompacted clean fine sand.

Stratum H is $4.23 \mathrm{ft}$ thick and extends from 102.08 to $106.31 \mathrm{ft}$ above NAVD 88 (fig. 7). This stratum is characterized by silty to slightly silty fine sand and humus associated with the soil A horizon (Hammonton LAF core 03, app 4). Results of HPT testing show pressures less than 40 psi and flow rates generally greater than $250 \mathrm{~mL} / \mathrm{min}$. Natural-gammaradiation measurements are near background levels. Sediment descriptions and results of HPT testing and natural-gammaradiation logging all indicate that stratum $\mathrm{H}$ is not hydraulically restrictive.

Peaks in natural-gamma radiation are correlated between selected logged wells to map the extent of lower hydraulic conductivity units in the strike and dip sections. The altitude of the contact between the Cohansey Formation and the Bridgeton Formation and weathered Coastal Plain deposits varies throughout the site, but generally is within $2 \mathrm{ft}$ of the position observed at PZ 6 (fig. 7). The units of the New Jersey Coastal Plain generally strike northeast-southwest and dip gently to the southeast (Zapecza, 1989). Three sections along strike and two sections along dip through the Hammonton
LAF were examined (figs. 8 and 9 a-e). Section $C-C^{\prime}$ (fig. $9 \mathrm{~b})$ runs along strike through the center of the facility and includes well PZ 6 . The position of section $C-C^{\prime}$ ' allows direct comparison of other wells within the section to the naturalgamma and HPT logs from well PZ 6. The three shallowest lower conductivity zones are observed in all wells; the deepest is observed in wells MW 6, PZ 2, and PZ 6. Bedding is nearly horizontal in this section and altitude is relatively constant along the section. Section $E-E$ ' (fig. 9d) runs parallel to the dip direction and includes wells PZ 6 and Nest $11 \mathrm{MW}$ C. The four shallowest lower conductivity zones observed in well Nest $11 \mathrm{MW}$ C correlate with the shallowest lower conductivity zone identified in PZ 6. The deeper two lower conductivity zones in well Nest 11 MW C correlate with the second shallowest lower conductivity zone identified in PZ 6. The third shallowest lower conductivity zone was observed only in PZ 6, likely as a result of erosion, as evidenced by the topography of this section. As in section $C-C^{\prime}$, bedding is nearly horizontal, indicating that the lower conductivity zones are planar features. The depth of the deepest lower conductivity zone identified in well PZ 6 is located in section $D-D$ ' by correlation with MW 47 (fig. 9c). A lower conductivity zone in Nests 8 MW C and MW 9 between 90 and $95 \mathrm{ft}$ may correlate with the shallowest lower conductivity zone initially identified in PZ 6 and well Nest 11 MW C, indicating that the middle two lower conductivity zones identified in sections $C-C$ ' and $E-E$ ' may not extend to the eastern portion of the Hammonton LAF. Identification of the deepest lower conductivity zone in sections $B-B$ ' and $F-F^{\prime}$ ' (figs. $9 \mathrm{a}$ and e) indicates that the zone is present throughout the Hammonton LAF. The origin of this and other lower conductivity zones is unclear. Because the Bridgeton Formation is a series of fluvial deposits, it is possible that these nearly horizontal and continuous to semicontinuous zones may be remnants of floodplains. Alternatively, these zones may have been created post-deposition by iron cementation of sands associated with paleo-groundwater fluctuations.

Zones of reduced hydraulic conductivity can be present without a corresponding increase in natural-gamma radiation. HPT testing near well Nest 11 identified six zones of reduced hydraulic conductivity, including five zones ranging from 0.1 to $0.9 \mathrm{ft}$ thick with flow rates equal to $0 \mathrm{~mL} / \mathrm{min}$ (fig. 10). Taken together, these zones correlate with stratum E (fig. 7). Of the six zones identified, only one correlates with increased gamma-radiation emissions. Coring at the HPT test site confirms the presence of interfingered clay and coarse sand from 4.7 to $6.0 \mathrm{ft}$ below land surface (bls) and the presence of ironstone from 6.4 to $6.6 \mathrm{ft}$ bls. Only units containing minerals with relatively high concentrations of potassium- 40 (such as feldspar- and mica-rich clays) emit enough gamma photons to generate a "peak" within a gamma log. Although the ironstone present from 6.4 to $6.6 \mathrm{ft}$ bls affects the hydraulic conductivity of the stratum (as evidenced by the HPT $\log$ ), it does not contain enough potassium-40 to cause an increase in gamma radiation. Pressure and flow measurements made by 


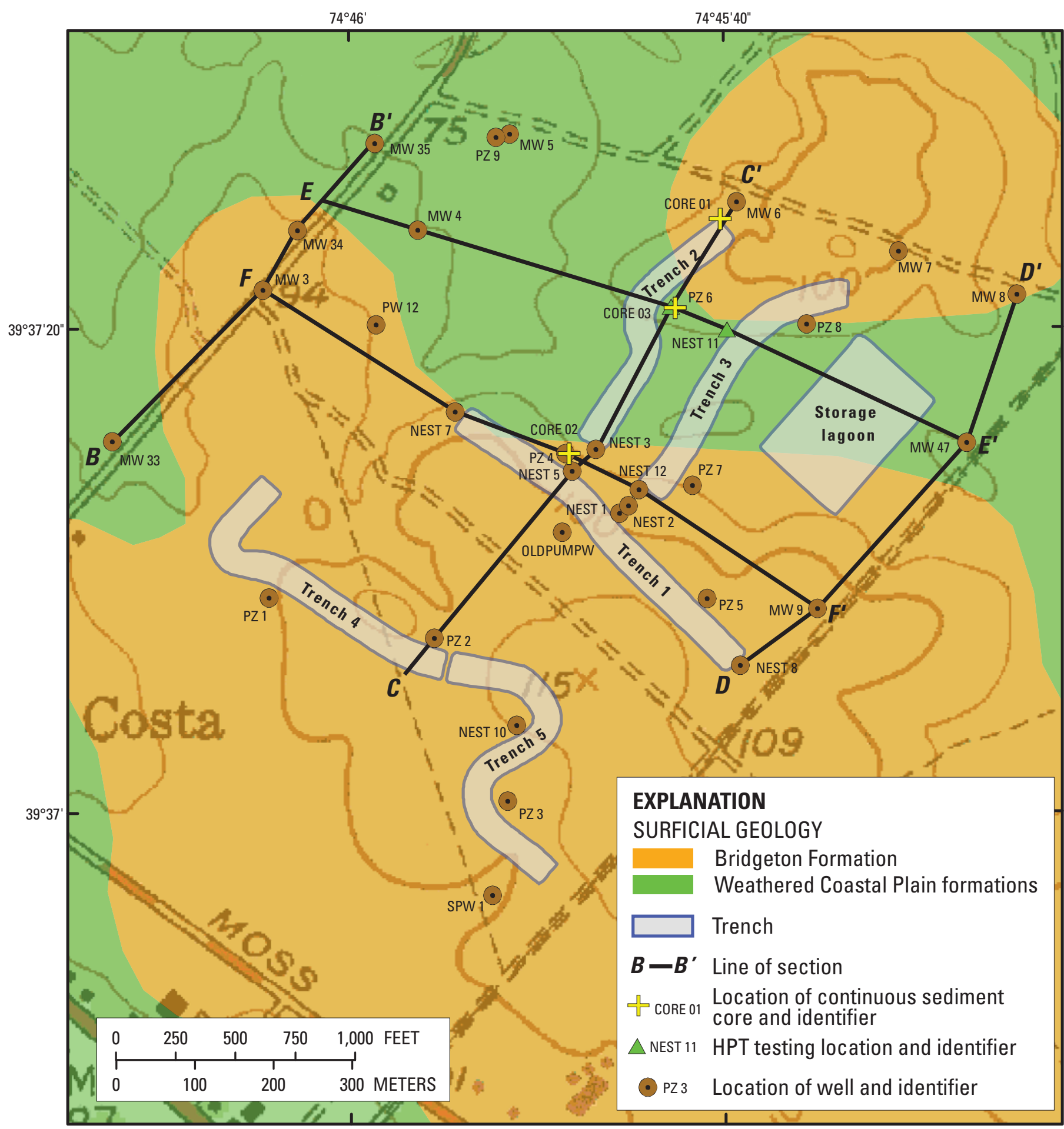

Geology from Pristas, 2004

Figure 8. Locations of wells, trenches, continuous sediment cores, Hydraulic Profiling Tool (HPT) testing, and lines of section, Hammonton Land Application Facility, southern New Jersey. 
A.

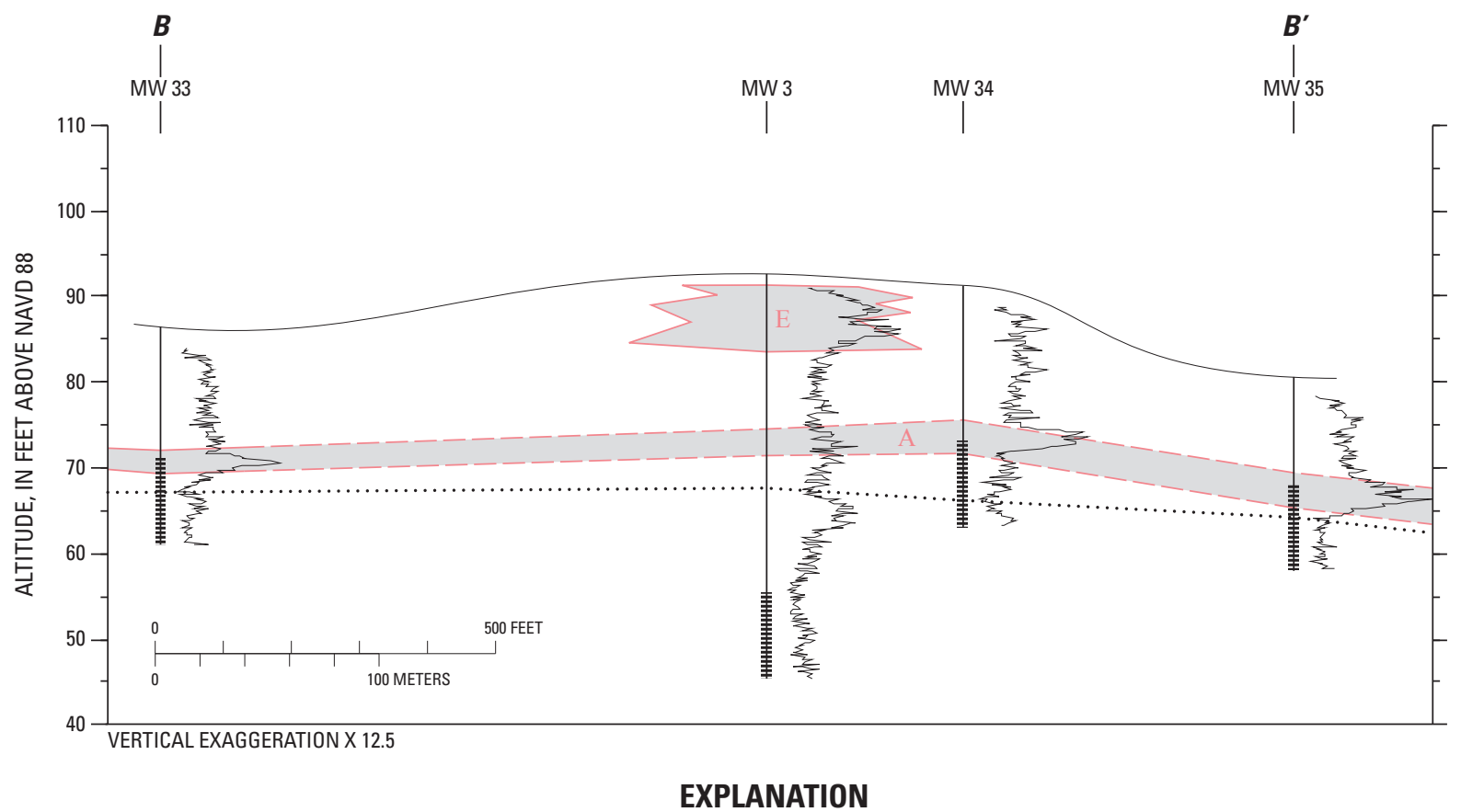

A Contact between strata. Letter is stratum identifier shown in figure 7. Dashed where approximate

Contact between the Cohansey Formation and the Bridgeton Formation and weathered Coastal Plain deposits

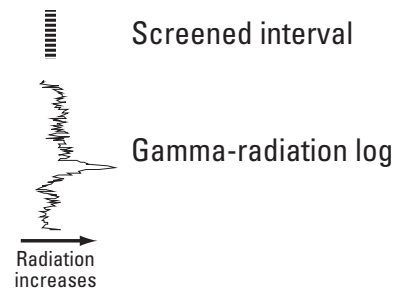

Figure 9. Hydrogeologic cross sections $(A) B-B^{\prime},(B) C-C^{\prime},(C) D-D^{\prime},(D) E-E^{\prime}$, and $(E) F-F^{\prime}$, Hammonton Land Application Facility, southern New Jersey. 
B.

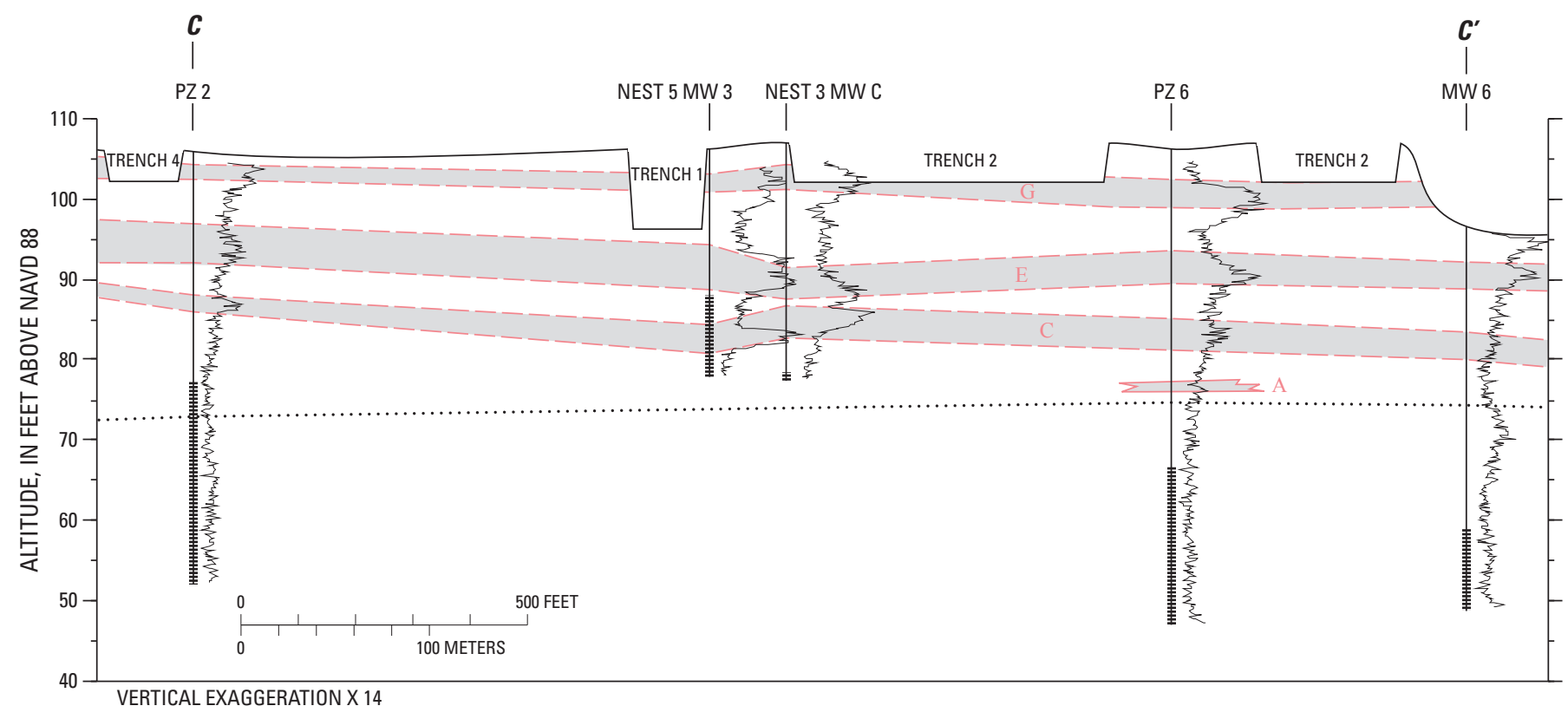

\section{EXPLANATION}

Contact between strata. Letter is stratum identifier shown in figure 7. Dashed where approximate

Contact between the Cohansey Formation and the Bridgeton Formation and weathered Coastal Plain deposits

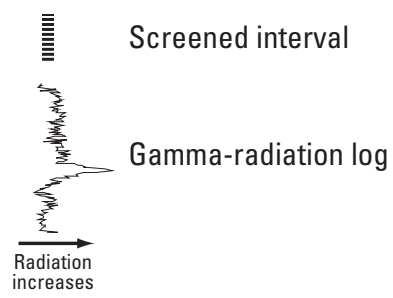

Figure 9. Hydrogeologic cross sections $(A) B-B^{\prime},(B) C-C^{\prime},(C) D-D^{\prime},(D) E-E^{\prime}$, and $(E) F-F^{\prime}$, Hammonton Land Application Facility, southern New Jersey.-Continued 
C.

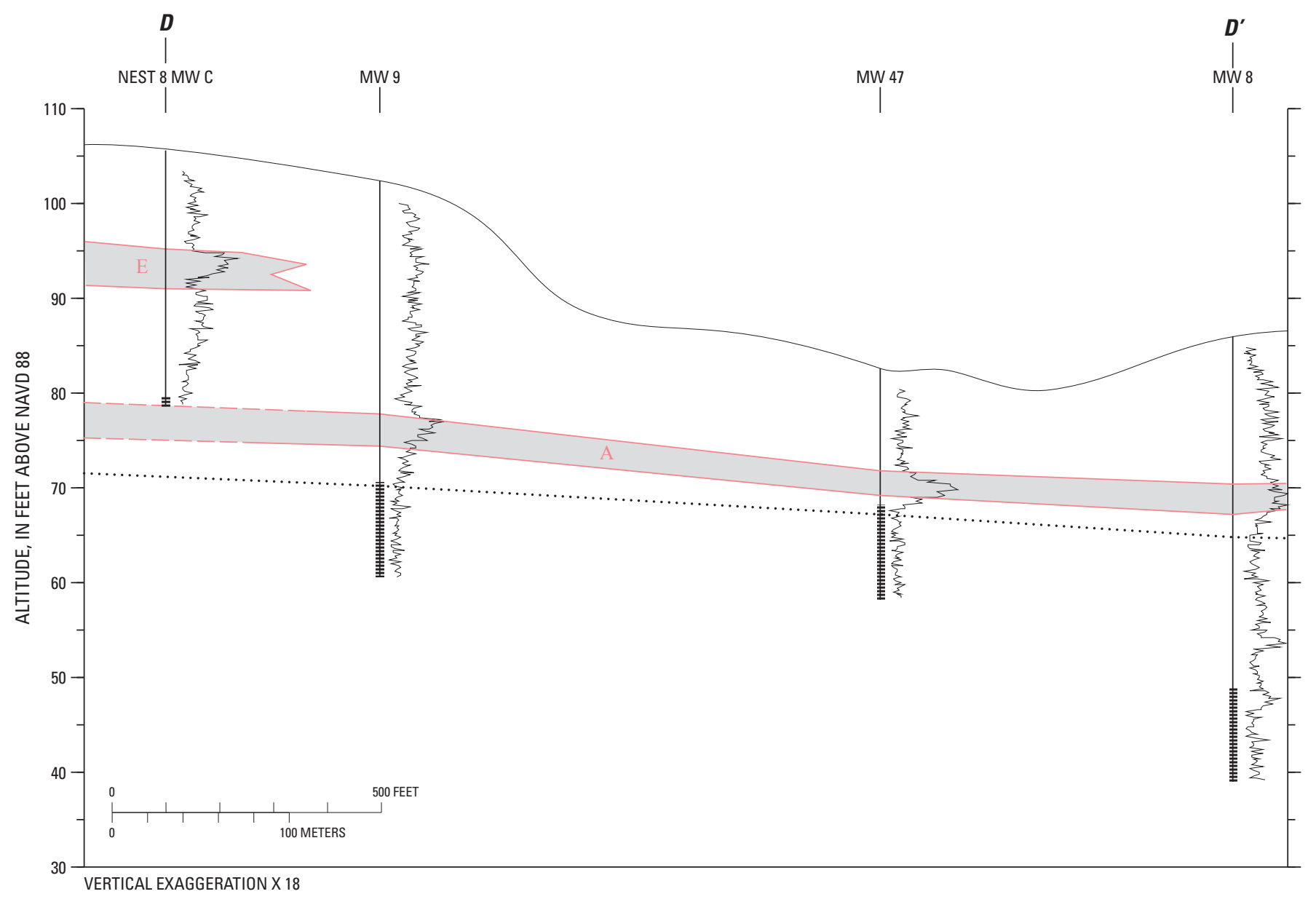

EXPLANATION

A Contact between strata. Letter is stratum identifier shown in figure 7. Dashed where approximate

Contact between the Cohansey Formation and the Bridgeton Formation and weathered Coastal Plain deposits

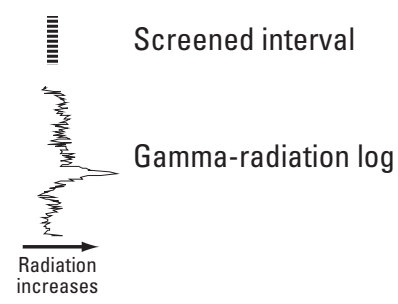

Figure 9. Hydrogeologic cross sections $(A) B-B^{\prime},(B) C-C^{\prime},(C) D-D^{\prime},(D) E-E^{\prime}$, and $(E) F-F^{\prime}$, Hammonton Land Application Facility, southern New Jersey.-Continued 


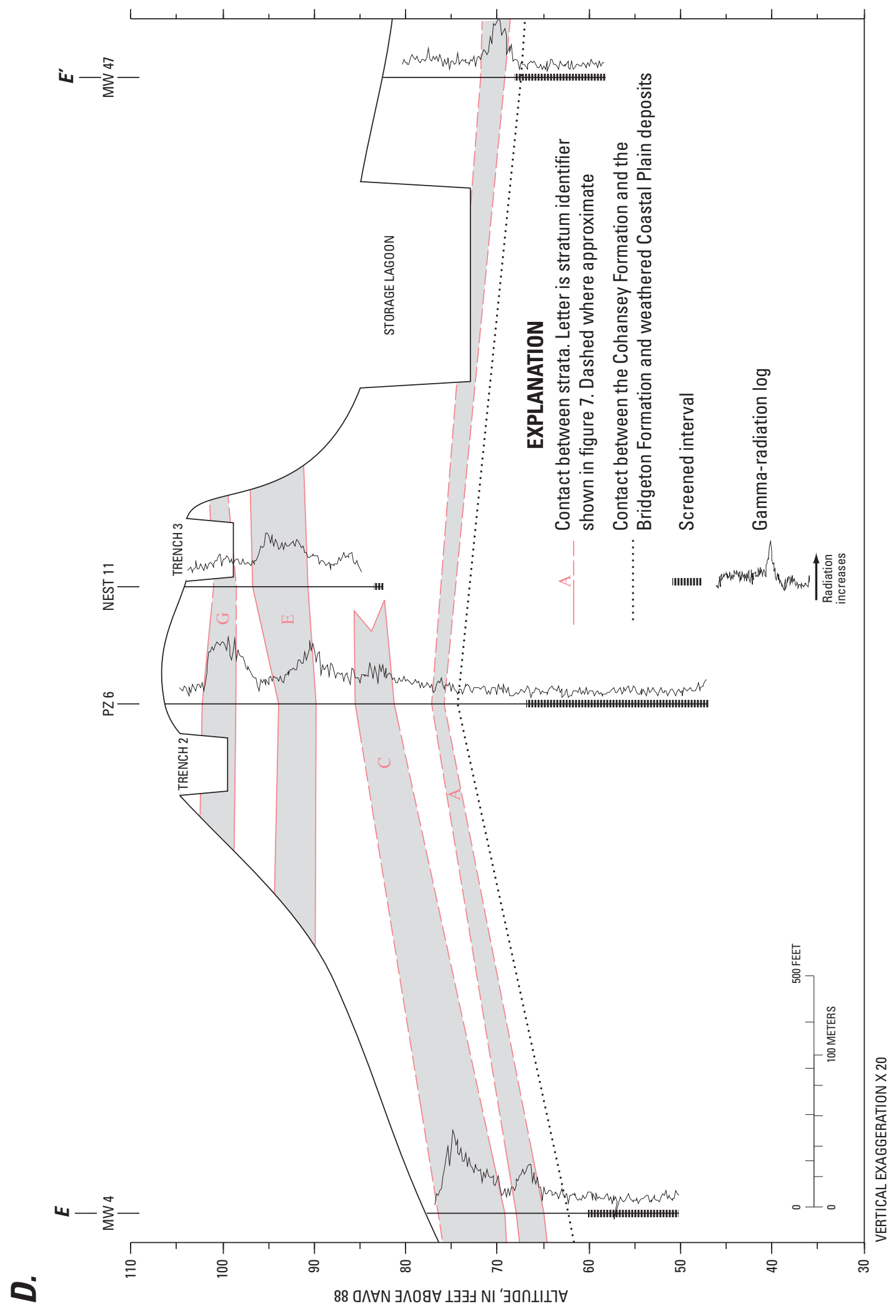

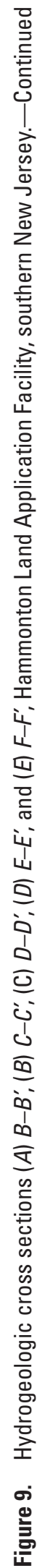




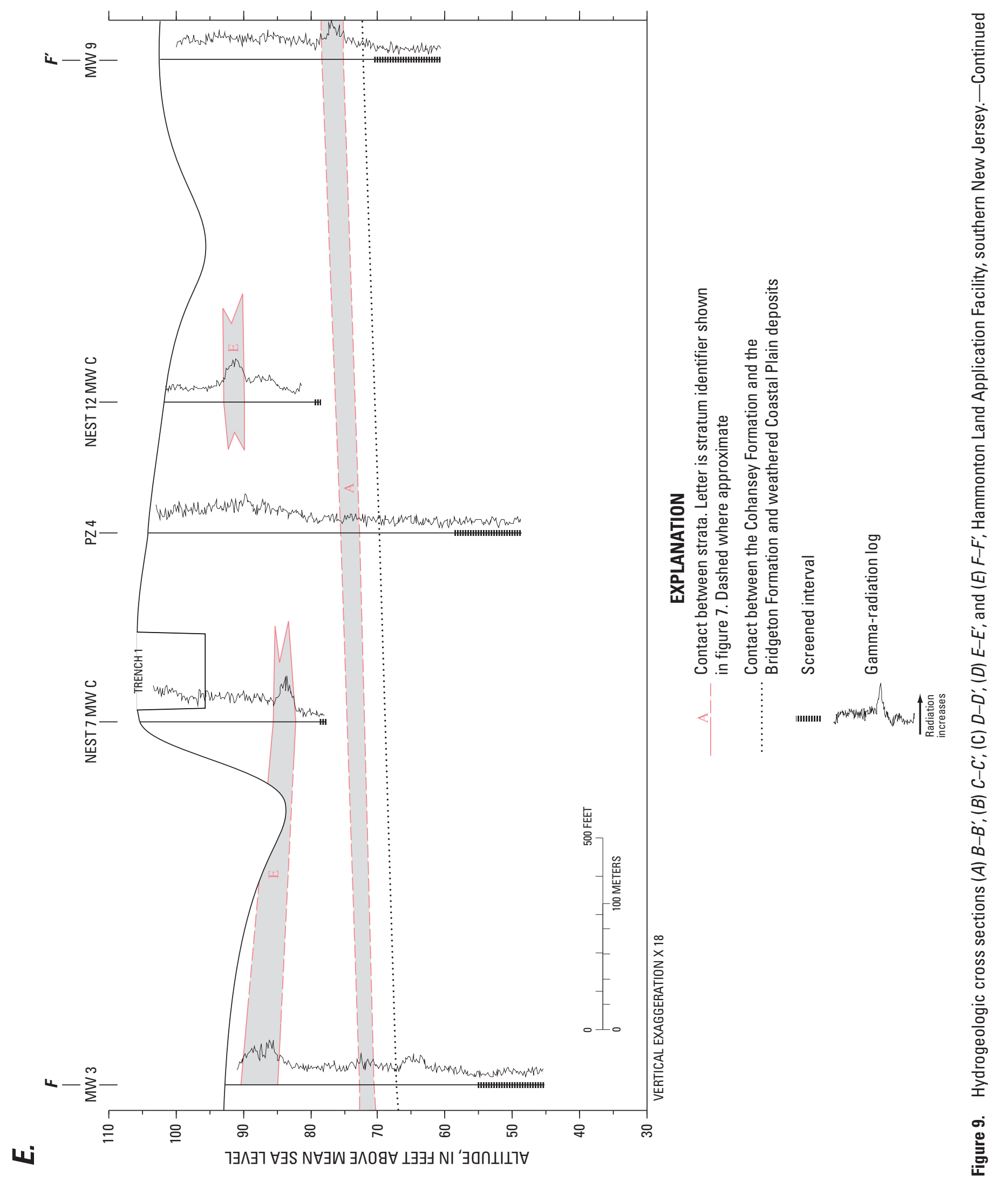




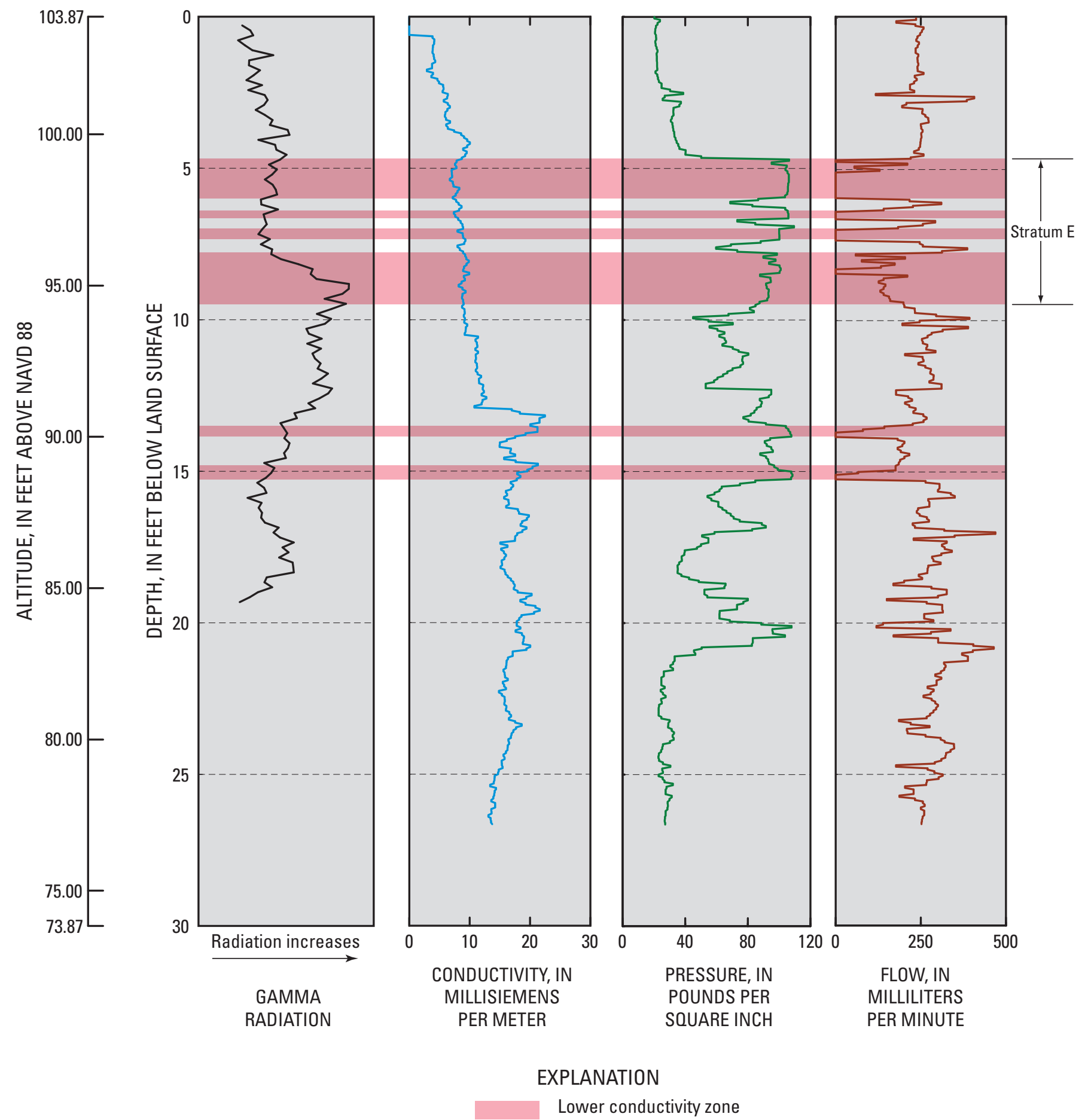

Figure 10. Geophysical logs of well Nest 11 MW C, Hammonton Land Application Facility, southern New Jersey. 
the HPT system are frequent (20 measurements per foot) and test the properties of the sediment in contact with the approximately 0.5 -in. injection screen. Although gamma-radiation measurements are made at the same frequency, the gamma probe counts the number of photons emitted within a 6- to 12-in. radius (Keys and McCary, 1971). Emissions from beds with a thickness less than 12 to 24 in. (like the interfingered clays noted between 4.7 and $6.0 \mathrm{ft}$ bls) are not recorded at full strength because the radius of the measurement is never fully occupied by the bed (Keys and McCary, 1971).

\section{Observation of Perched Water}

On January 11, 2007, USGS personnel hand-augured a hole adjacent to Nest 11 to determine the nature of an observed gamma-radiation high that began at about $8 \mathrm{ft}$ bls and peaked at $9 \mathrm{ft}$ bls during gamma logging of well Nest 11 MW C (fig. 10). The hand-augured hole was $20 \mathrm{ft}$ west of trench 3 and $3 \mathrm{ft}$ east of well Nest $11 \mathrm{MW} \mathrm{C} \mathrm{(fig.} \mathrm{11).} \mathrm{The} \mathrm{hole}$ was dug to refusal at approximately $6 \mathrm{ft}$ deep and then began to fill with water. The water level in the hole rose to $4.9 \mathrm{ft}$ bls.

Water levels in PZ 7, Nest 11, and Nest 12 were measured and water levels in trenches 1,2 , and 3 were retrieved from the operational database assembled as part of this study (table 4). Piezometer water levels from January 11, 2007, indicate the presence of perched water at three different altitudes underlying the Hammonton LAF (table 4). The water level in the augured hole is the shallowest perched water and is higher than the water level in trench 1 and lower than the water levels in trenches 2 and 3. Based on the location of the augured hole, the source of the perched water could be trench 2 , trench 3 , or precipitation. The water level in well Nest $11 \mathrm{MW}$ A is $5.27 \mathrm{ft}$ lower than that in the augured hole only $3 \mathrm{ft}$ away. Well Nest $11 \mathrm{MW}$ A is $5.49 \mathrm{ft}$ deeper than the augured hole and is screened over a $1-\mathrm{ft}$ interval, indicating that they intersect different lenses of perched water rather than a steeply sloping perched water surface. Perhaps coincidently, the floor of trench 1 is $0.1 \mathrm{ft}$ above the water level observed in well Nest $11 \mathrm{MW}$ A. Perched water in Nest $12 \mathrm{MW}$ A was also $3.74 \mathrm{ft}$ lower than that in trench 1 . The range of observed perchedwater-level altitudes indicates that water likely is perched on multiple layers throughout the facility. Given the presence of many low-permeability zones throughout the site, layers of perched water probably also are common throughout the site. The presence of perched water and the restrictive strata that cause perching reduce the rate at which water from the trenches can infiltrate to the water table.

\section{Water Quality}

Water-quality samples were collected from the Hammonton WWTP, storage lagoon, trench 2, MW 5, and MW 8 in December 2006 and May 2007 to determine whether waterquality characteristics vary seasonally (table 5 , at end of report, and figs. 12-14).

Composite (24-hour) samples of Hammonton WWTP effluent collected on December 2, 2006, and May 2, 2007, are similar (figs. 12a, 13a, and 14a). Differences in ion concentrations were greatest between sodium and chloride. Even so, the average deviation was $1.46 \mathrm{mg} / \mathrm{L}( \pm 3.0$ percent of the mean $)$

Table 4. Well-constuction information, water levels, and altitude of wells and trenches used to determine altitude of perched water tables, Hammonton Land Application Facility, southern New Jersey.

[--, not available; NAVD 88, North American Vertical Datum of 1988]

\begin{tabular}{|c|c|c|c|c|c|}
\hline Site & $\begin{array}{c}\text { Altitude } \\
\text { (feet above } \\
\text { NAVD 88) }\end{array}$ & $\begin{array}{c}\text { Depth } \\
\text { (feet above } \\
\text { NAVD 88) }\end{array}$ & $\begin{array}{c}\text { Open interval } \\
\text { (feet above } \\
\text { NAVD 88) }\end{array}$ & $\begin{array}{c}\text { Water level } \\
\text { (feet above } \\
\text { NAVD 88) }\end{array}$ & $\begin{array}{c}\text { Height above } \\
\text { water table } \\
\text { (feet) }^{1}\end{array}$ \\
\hline Nest $11 \mathrm{MW}$ A & 103.73 & 92.51 & $93.51-92.51$ & 93.83 & 24.03 \\
\hline Nest $11 \mathrm{MW} \mathrm{B}$ & 103.87 & 88.07 & $89.07-88.07$ & Dry & -- \\
\hline Nest 12 MW B & 101.38 & 83.38 & $84.38-83.38$ & Dry & -- \\
\hline Nest $12 \mathrm{MW} \mathrm{C}$ & 101.68 & 78.68 & $79.68-78.68$ & Dry & -- \\
\hline PZ 7 & 96.74 & 48.62 & $73.62-48.62$ & 71.90 & 0.00 \\
\hline Trench 1-floor & 93.93 & -- & -- & 94.37 & 24.57 \\
\hline
\end{tabular}

${ }^{1}$ The water-table altitude as measured in PZ 7 on 1/11/07 at 1259 . 


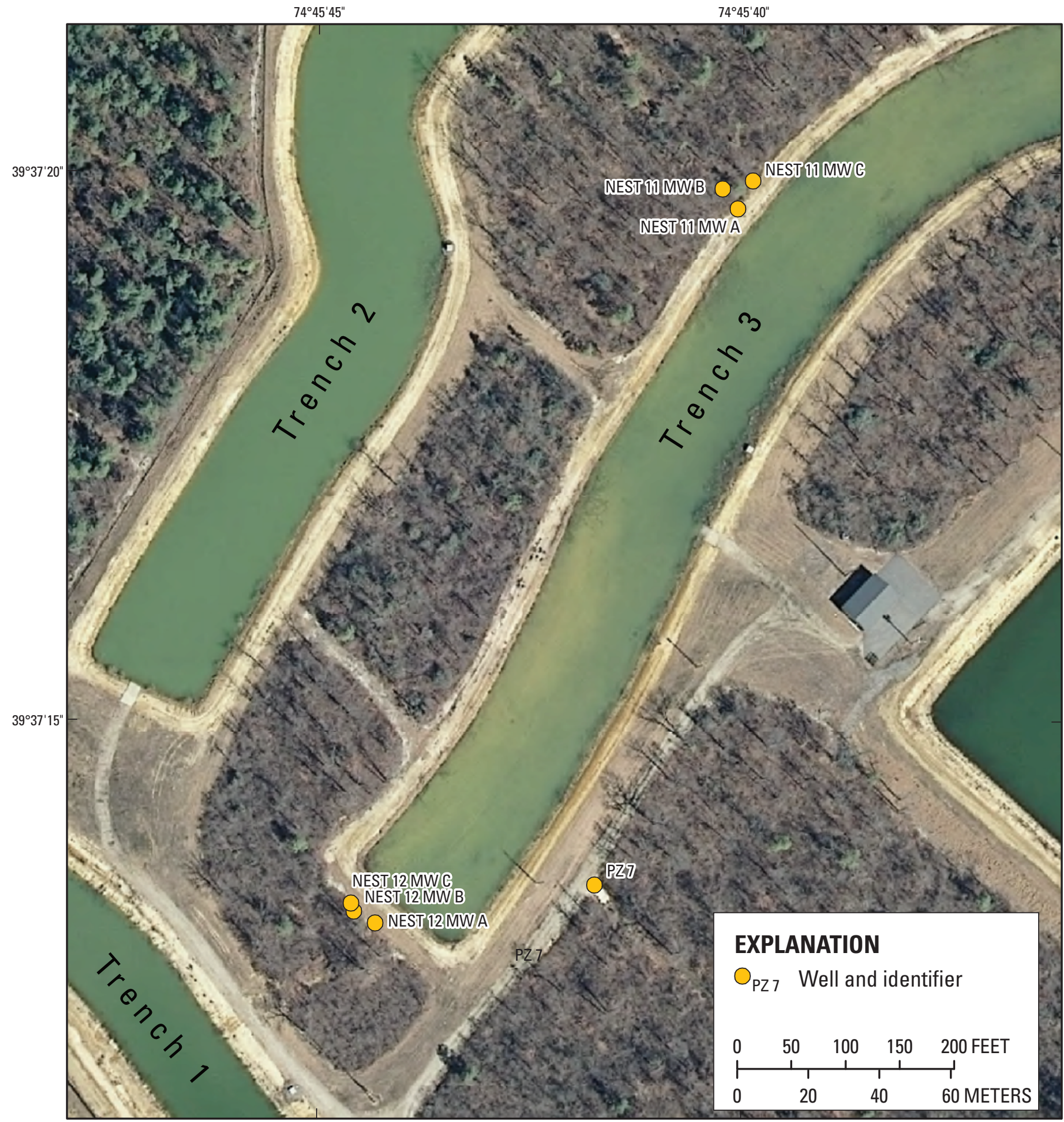

Orthophoto from New Jersey Office of Information Technology, Office of Geographic Information Systems, 2008

Figure 11. Locations of wells used to determine the altitude of perched water, Hammonton Land Application Facility, southern New Jersey. 


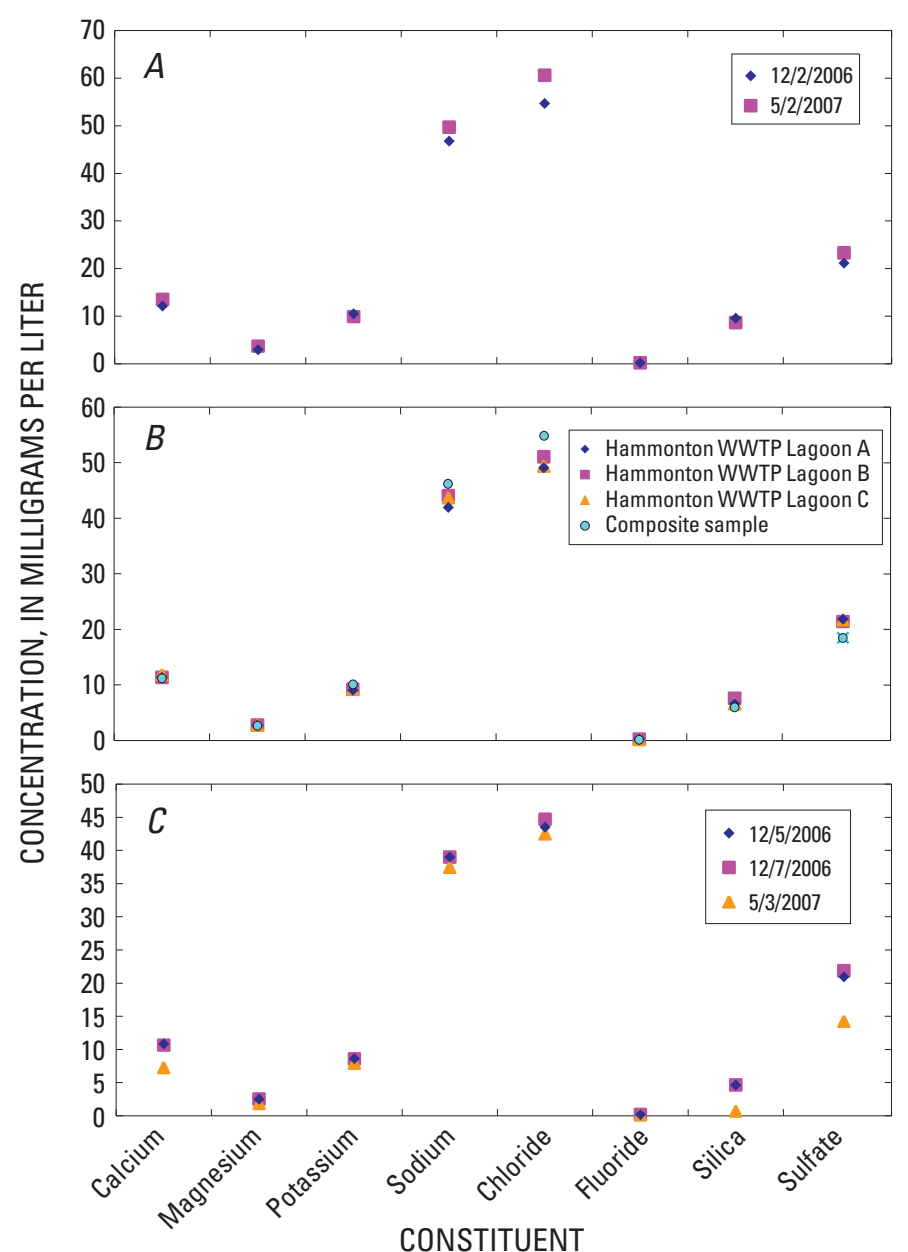

Figure 12. Concentrations of selected ions in $(A)$ 24-hour composite samples of treated effluent collected at the Hammonton Waste Water Treatment Plant (WWTP) on December 2, 2006, and May 2, 2007; (B) samples of treated wastewater collected from the storage lagoons at the Hammonton Land Application Facility (LAF) on December 6, 2006, and May 3, 2007 (composite sample); and (C) samples of treated wastewater collected from trench 2 at the Hammonton LAF on December 5 and 7, 2006, and May 3, 2007, southern New Jersey.

for the sodium measurements and $2.96 \mathrm{mg} / \mathrm{L}( \pm 5.1$ percent of the mean) for the chloride measurements. Although greater than the precision of these measurements (app. 3), these differences are small and indicate that the major-ion composition of treated effluent leaving the treatment facility was consistent during this study. Nutrient concentrations in the Hammonton WWTP effluent between the two sampling periods were more variable (fig. 13a). Measurements of filtered nitrate plus nitrite and unfiltered ammonia plus organic nitrogen were similar between the two sampling periods. Concentrations of

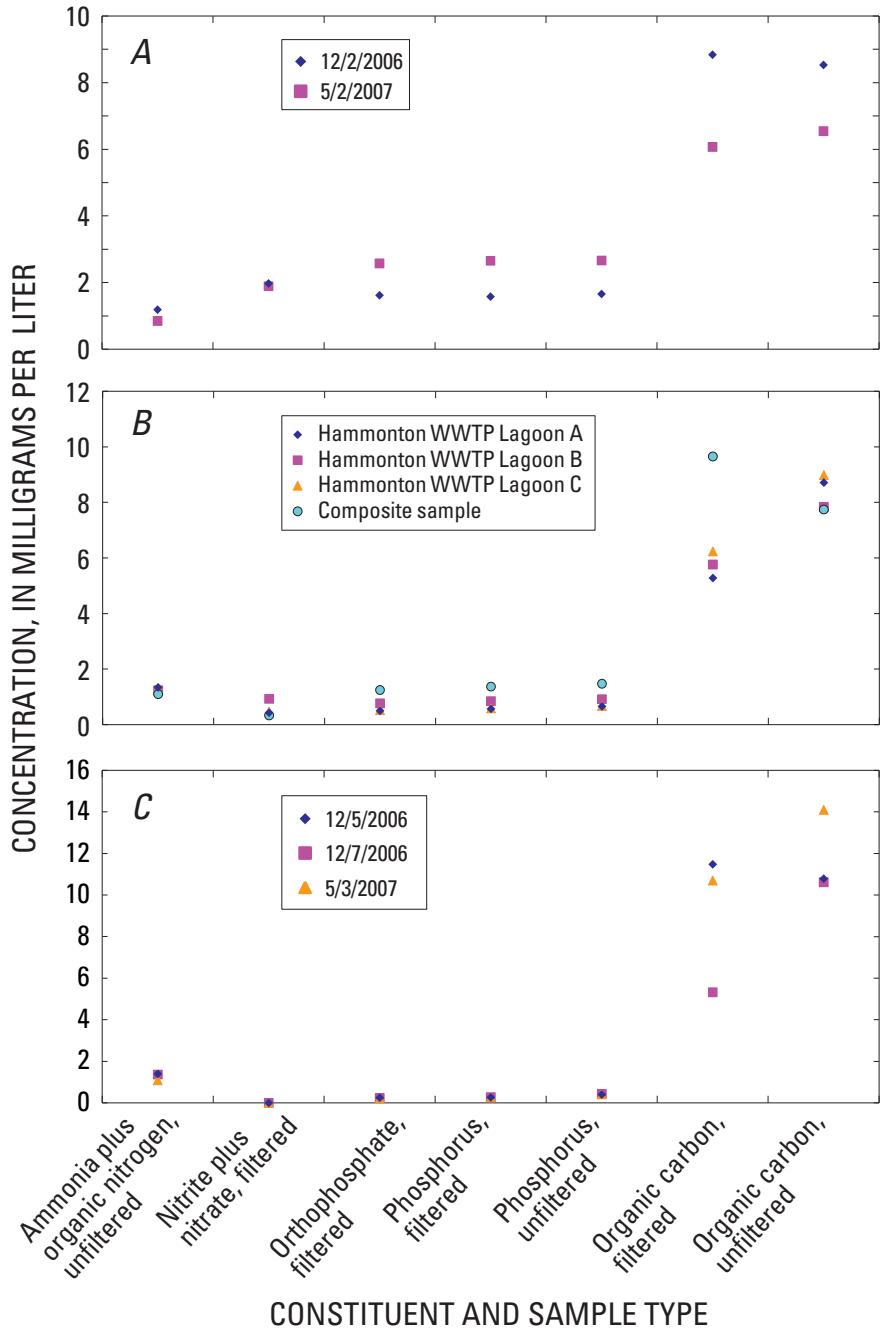

Figure 13. Concentrations of selected nutrients in $(A)$ 24-hour composite samples of treated effluent collected at the Hammonton Waste Water Treatment Plant (WWTP) on December 2, 2006, and May 2, 2007; $(B)$ samples of treated wastewater collected from the storage lagoons at the Hammonton Land Application Facility (LAF) on December 6, 2006, and May 3, 2007 (composite sample); and $(C)$ samples of treated wastewater collected from trench 2 at the Hammonton LAF on December 5 and 7, 2006, and May 3, 2007, southern New Jersey.

phosphorus ranged from about 1.5 to $2.5 \mathrm{mg} / \mathrm{L}$ and those of organic carbon ranged from about 6 to $9 \mathrm{mg} / \mathrm{L}$. These differences are likely related to daily or seasonal differences in the composition of the wastewater received by the plant. The fact that most nutrient and carbon concentrations were similar in filtered and unfiltered samples indicates that the WWTP is effective at removing particulate matter.

Vertical composite samples collected from three locations within the storage lagoon in December 2006 contained similar concentrations of selected ions, nutrients, and trace elements 


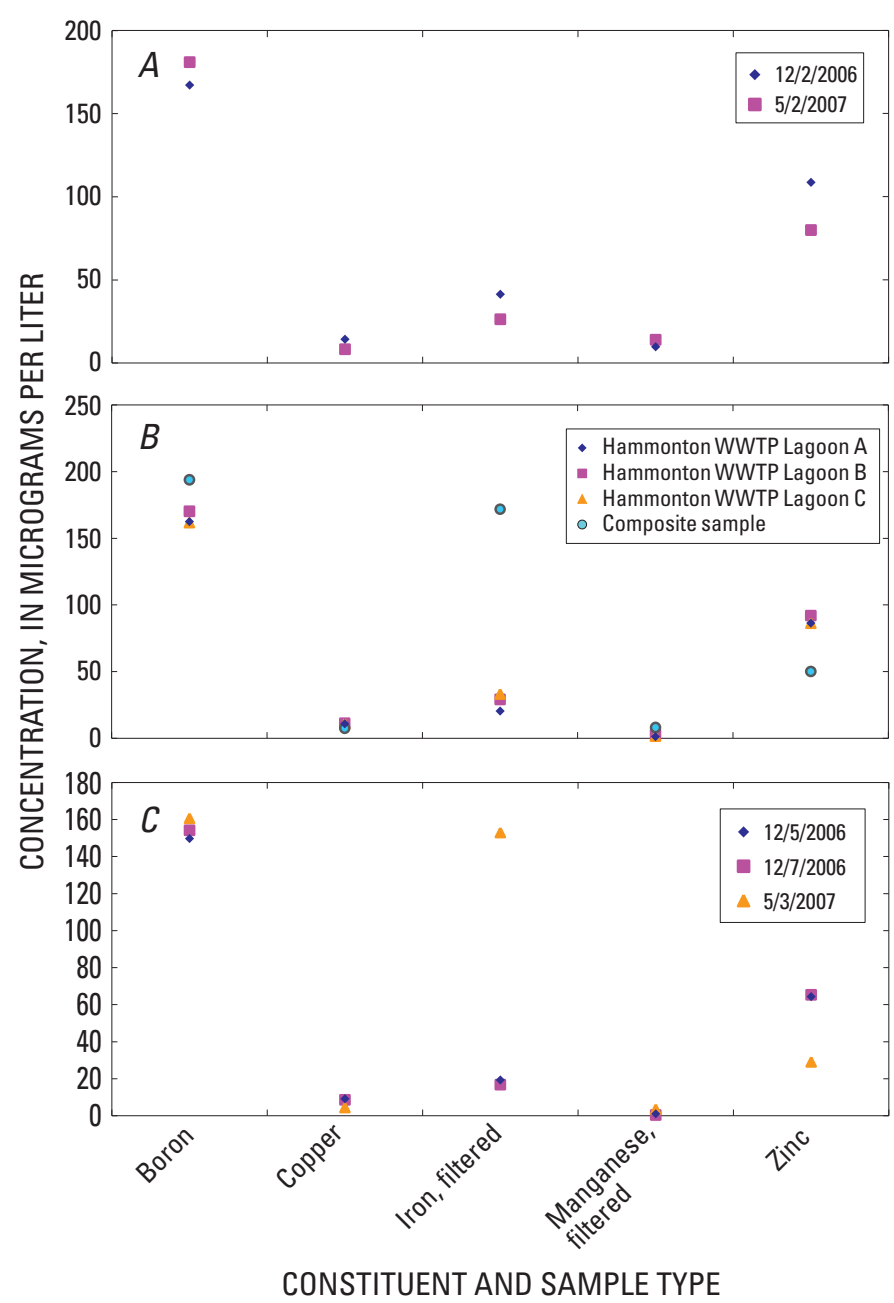

Figure 14. Concentrations of selected trace elements in $(A)$ 24-hour composite samples of treated effluent collected at the Hammonton Waste Water Treatment Plant (WWTP) on December 2, 2006, and May 2, 2007; (B) samples of treated wastewater collected from the storage lagoons at the Hammonton Land Application Facility (LAF) on December 6, 2006, and May 3, 2007 (composite sample); and $(C)$ samples of treated wastewater collected from trench 2 at the Hammonton LAF on December 5 and 7, 2006, and May 3, 2007, southern New Jersey.

(figs. 12b, 13b, and 14b), which indicates that the storage lagoon is well mixed both laterally and vertically. Vertical profiles of temperature, $\mathrm{pH}, \mathrm{DO}$, and SC collected in December 2006 and May 2007 indicate little vertical stratification. Therefore, during follow-up sampling in May 2007, a single vertically and spatially composited sample was collected.

As with the WWTP, some differences in the chemistry of the water in the storage lagoon were noted between the concentrations in the May 2007 sample and the mean concentrations in December 2006 (figs. 12b, 13b, and 14b).
Concentrations of nitrogen and ammonia in the winter and spring samples were similar, but phosphorus concentrations in filtered samples ranged from 0.56 to $1.37 \mathrm{mg} / \mathrm{L}$, total organic carbon concentrations ranged from 7.74 to $8.98 \mathrm{mg} / \mathrm{L}$, and dissolved organic carbon concentrations ranged from 5.27 to 9.65 $\mathrm{mg} / \mathrm{L}$ (ranges similar to those noted for the WWTP). Concentrations of iron, manganese, and zinc varied more than those of the other trace elements. These variations also likely are related to daily or seasonal fluctuations in the composition of wastewater received by the plant, as they also were observed in samples of the WWTP effluent. Because the lagoon supplies water to the trenches, similar seasonal differences also were observed in trench water samples.

As water moves from the WWTP into the storage lagoon and then to the trenches, its chemistry changes. In general, concentrations of conservative ions $(\mathrm{Ca}, \mathrm{Mg}, \mathrm{K}, \mathrm{Na}$, and $\mathrm{Cl}$ ) and indicators ( $\mathrm{SC}$ and hardness) decreased by about 10 percent from the plant to the storage lagoon, and decreased about another 10 percent from the lagoon to the trenches (figs. 15, 16 , and 17; table 5, at end of report). This reduction in concentration is likely due to dilution from precipitation running into the lagoon and trenches. Other chemical changes are greater than those noted above and are likely caused by biologically mediated reactions typically seen in rivers and lakes. These include reduced concentrations of dissolved nitrate, phosphorus, silica (used in the production of diatom shells), and organic carbon, as well as increases in $\mathrm{pH}$ and the appearance of particulate carbon. Other changes, such as increased turbidity and DO, may be attributable to biological reactions, but also may be due to agitation from wind or waterfowl. The water-quality data do not exclude the possibility that cements or concretions are forming at the sediment/water interface; however, compared to other physical and hydrologic impediments to infiltration, the observed concentrations of cations and anions are dilute enough that they are not likely to be the cause of the poor infiltration rates at the site.

The characteristics of the water applied to the trenches at the Hammonton LAF are different from those of the infiltrating precipitation and the underlying groundwater. These characteristics must be known to determine the fate and potential water-quality effects of the infiltrated wastewater. Constituents such as sodium and chloride are conservative (not likely to react in the subsurface) and can be used as indicators of infiltrating effluent. Although sodium and chloride are derived from both natural and anthropogenic sources in this setting, concentrations in the effluent are much greater than those in any other potential source. Concentrations of boron above background levels indicate the presence of either treated or untreated wastewater. Boron enters the waste stream as sodium tetraborate (borax), a widely used cleaning agent and detergent (Hem, 1992). For instance, the sample of water from well Nest 11 well A contained similar or slightly lower concentrations of sodium, chloride, and boron than those measured in the water in trench 2 (table 5, at end of report), indicating that the primary source of this groundwater is the water from the trenches, although some dilution from precipitation may have occurred. Sorption to clays and organic carbon, in 


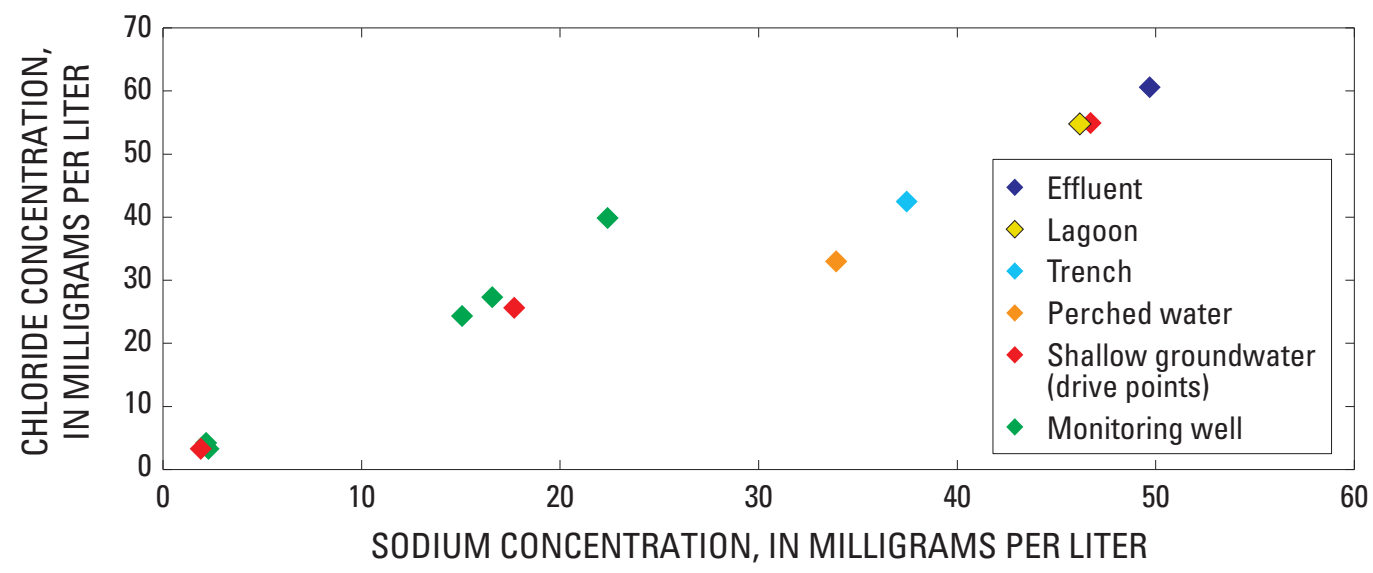

Figure 15. Relation between concentrations of sodium (filtered) and chloride (filtered) ions in samples of treated wastewater from selected locations within the Hammonton Waste Water Treatment Plant and Land Application Facility, southern New Jersey.

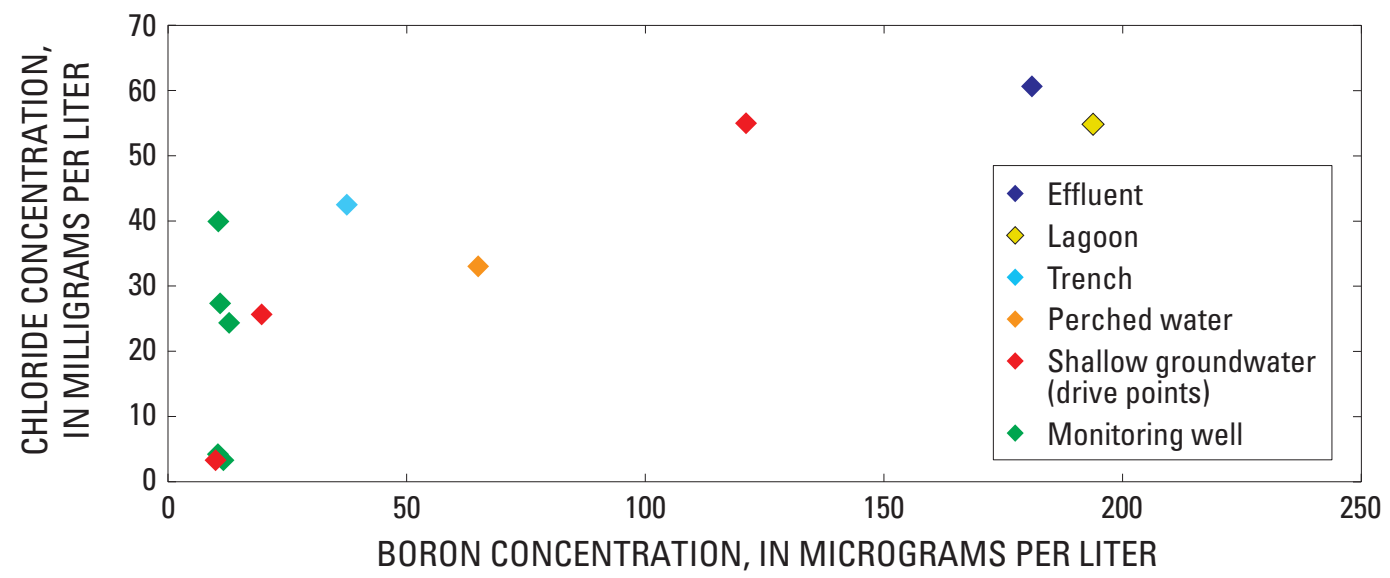

Figure 16. Relation between concentrations of boron (filtered) and chloride (filtered) ions in samples of treated wastewater from selected locations within the Hammonton Waste Water Treatment Plant and Land Application Facility, southern New Jersey.

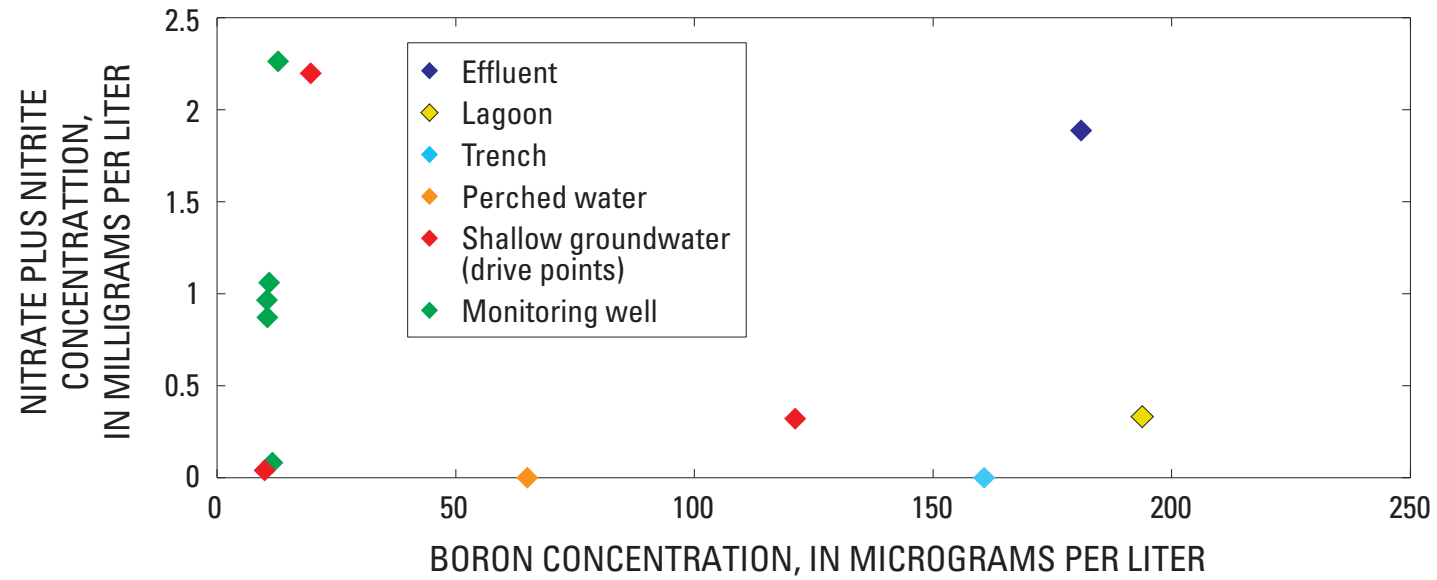

Figure 17. Relation between concentrations of boron (filtered) and nitrate plus nitrite (filtered) ions in treated wastewater from selected locations within the Hammonton Waste Water Treatment Plant and Land Application Facility, southern New Jersey. 
addition to dilution from infiltrated precipitation, could be responsible for the reduction in aqueous boron concentrations. Similarly, concentrations of sodium, chloride, and boron in the water sample collected from drive point DP 1 collected at the regional water table beneath the trenches were similar to those in water in trench 2, indicating that this is an area of recharge to the aquifer. Sodium, chloride, and boron concentrations in other drive-point samples (DP 2 and DP 3 ) from the regional water table and deeper piezometer samples (PZ 4, PZ 5, and PZ 6) from below the trenches were intermediate between those in the effluent and normal background concentrations-an indication that recharged water is mixing with groundwater. Concentrations of sodium, chloride, and boron in samples from the perimeter monitoring wells (MW 5 and MW 8) are similar to expected background concentrations.

Nitrate concentrations in selected monitoring wells and WWTP effluent are routinely sampled at Hammonton LAF by a New Jersey-certified drinking-water laboratory in accordance with the monitoring requirements set forth in their discharge permits. Analytical results for samples collected from MW 5 and MW 8 by the USGS during this study generally agree with results of this monitoring. All WWTP effluent samples collected by the USGS contained less than $2 \mathrm{mg} / \mathrm{L}$ nitrate plus nitrite (table 5 , at end of report), and concentrations in water in the trenches typically were less than the detection limit. Concentrations of nitrate plus nitrite measured in the water-table monitoring wells ranged from 0.04 to $2.26 \mathrm{mg} / \mathrm{L}$ and commonly were greater than concentrations measured in the trenches. Therefore, the presence of nitrate in groundwater at this facility does not indicate degradation of water quality due to infiltration of treated wastewater, but rather results from the mixing of nitrate from regional sources with infiltrated effluent containing little nitrate.
Concentrations of wastewater indicator compounds in treated effluent and groundwater were measured to differentiate wastewater from other water at the Hammonton LAF. Results are shown in table 6 . The detected compounds and their typical sources are listed in table 7 . The total concentration of wastewater indicator compounds and the number of detected compounds decrease along the treatment and infiltration pathway (fig. 18). The few compounds detected in samples of perched and shallow groundwater were not detected in samples from monitoring wells screened below the regional water table. Any of a number of mechanisms may be responsible for this condition. Degradation of triclosan and diethyl phthalate occurred after exposure of treated effluent to UV light within the treatment system; photochemical degradation of these compounds has been observed in laboratory experiments (Sanchez-Prado and others, 2006; Xu and others, 2007). Methyl salicylate was detected in effluent at concentrations less than the MRL post-UV light treatment and was not detected pre-UV light treatment. No reports of methyl salicylate formation as a result of UV light treatment could be found in the literature. The most likely explanation is that methyl salicylate is present pre-treatment below the MRL and simply was not detected. Attenuation of other waste indicator compounds while stored in the lagoon, while awaiting infiltration in the trench, and in groundwater could be the result of degradation (microbial or photodegradation), sorption to sediments or organic material, or dilution below the detection limit by mixing with infiltrated precipitation. Regardless of the mechanism(s), detections and concentrations of wastewater indicator compounds are substantially lower in groundwater underlying the Hammonton LAF than in all other parts of the Hammonton LAF, even in wells in which other tracers indicate the presence of treated wastewater.

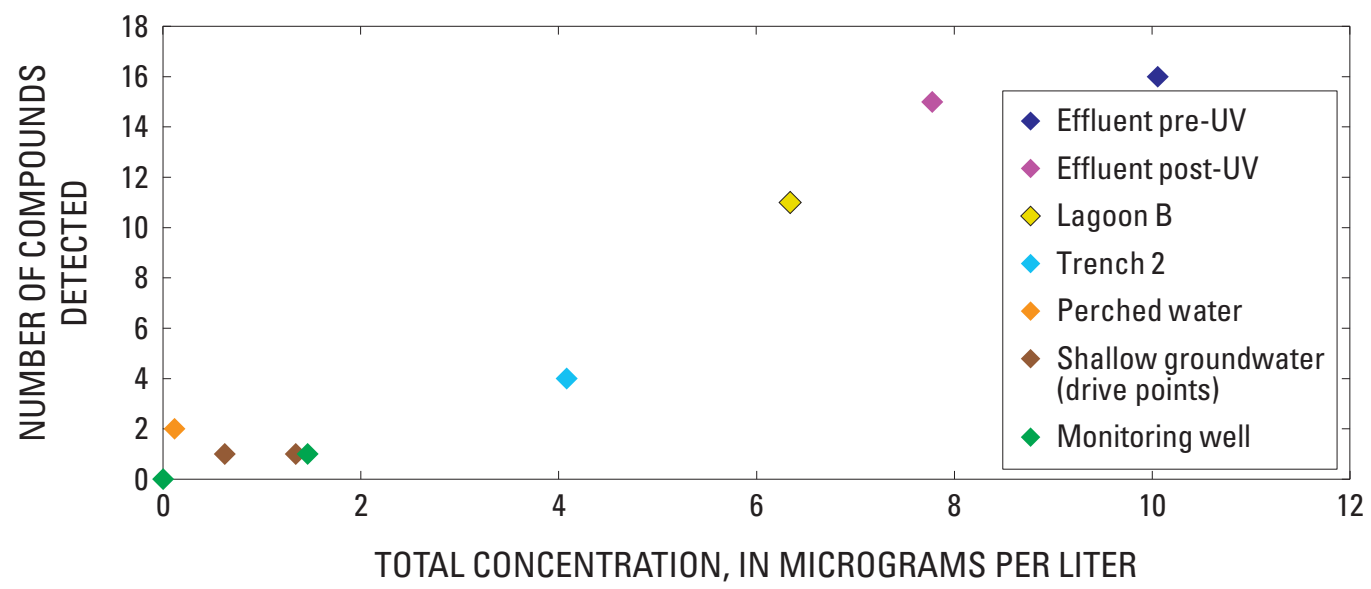

Figure 18. Relation between total concentration and number of wastewater indicator compounds detected in samples of treated wastewater from selected locations within the Hammonton Waste Water Treatment Plant and Land Application Facility, southern New Jersey. [UV, ultraviolet] 

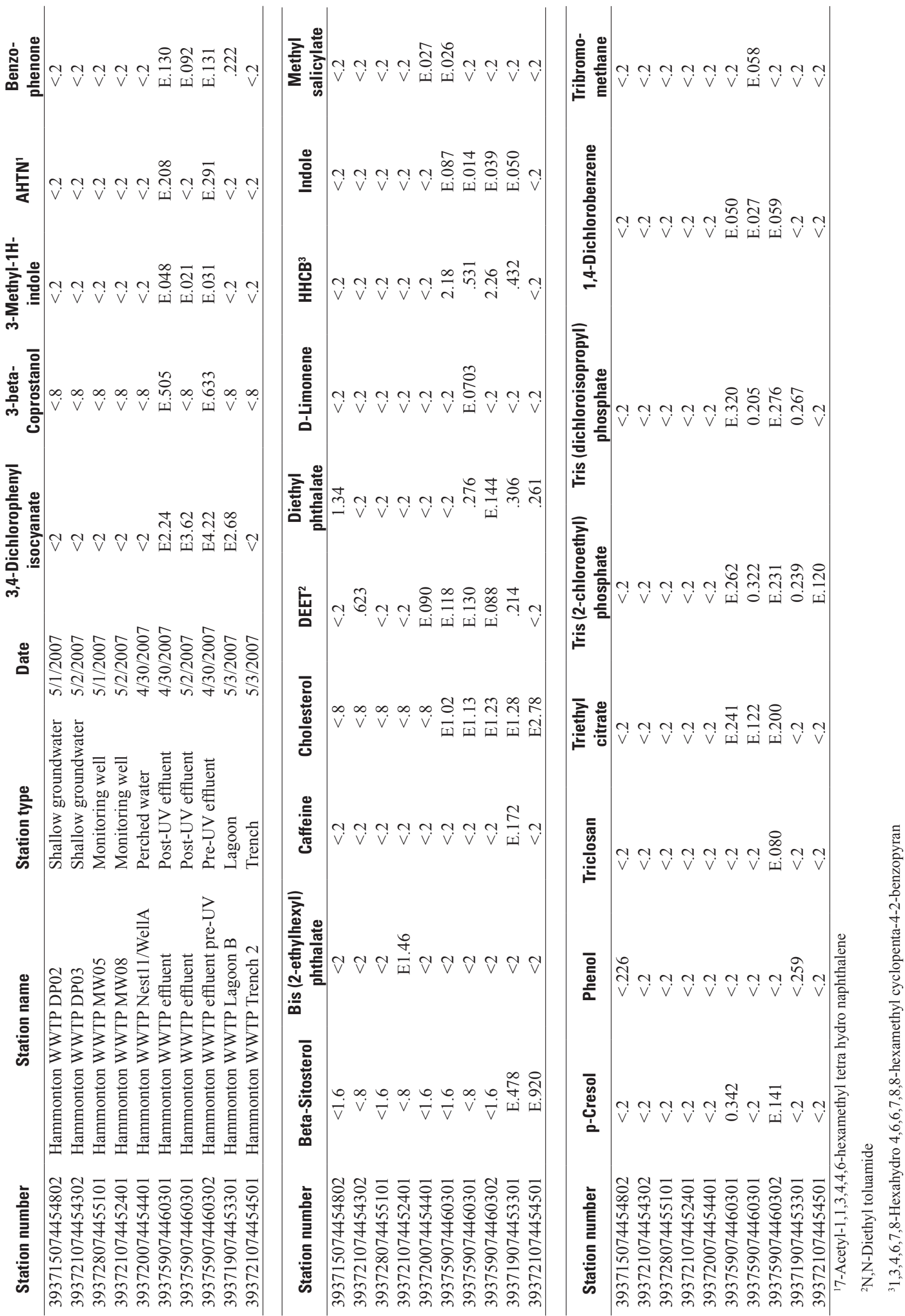


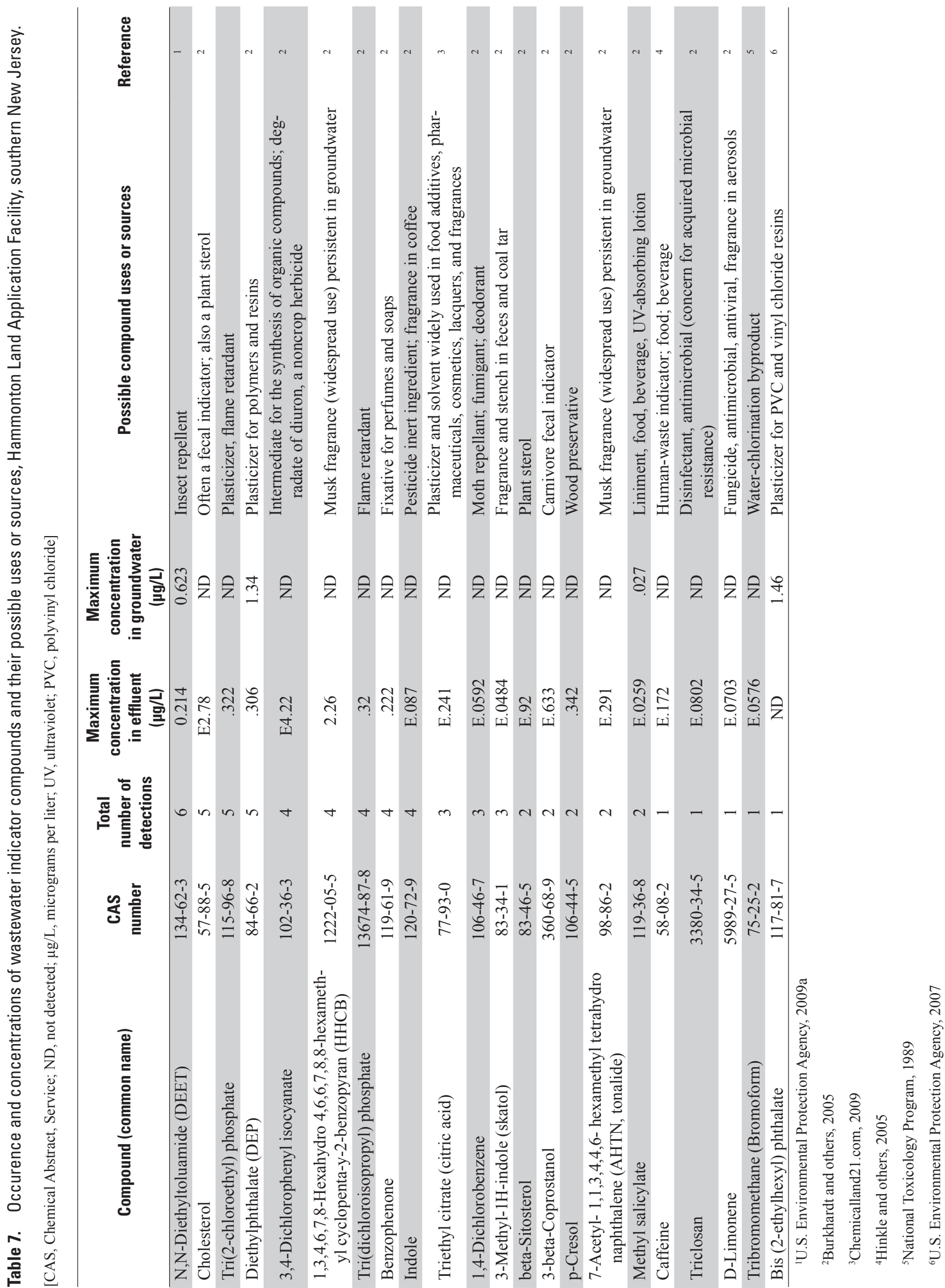




\section{Operation and Condition of Infiltration Trenches}

The 2002-07 operational data show that infiltration rates in trench 1 have declined while rates in trenches 2 and 3 have remained relatively stable (table 8 ). The average initial and resting infiltration rates in all trenches were 0.22 and $0.18 \mathrm{in} / \mathrm{hr}$ ( 0.56 and $0.47 \mathrm{~cm} / \mathrm{hr}$ ), respectively. Rates determined during pre-construction infiltration tests conducted in areas thought to be representative of trench locations averaged $8.27 \mathrm{in} / \mathrm{hr}$ $(21 \mathrm{~cm} / \mathrm{hr}$ ) (ARH Associates, 1993) (fig. 5). Infiltration tests were not conducted in any areas where infiltration trenches were ultimately constructed. The infiltration trenches and the storage lagoon were sized on the basis of an anticipated infiltration rate of $7.87 \mathrm{in} / \mathrm{hr}(20 \mathrm{~cm} / \mathrm{hr})$ and a design load of approximately $0.5 \mathrm{Mgal} / \mathrm{d}$ for each trench (ARH Associates, 1993). The highest infiltration rate observed during this study, $2.27 \mathrm{in} / \mathrm{hr}(5.77 \mathrm{~cm} / \mathrm{hr})$, occurred during the first loading of trench 1 in May 2002. Infiltration rates were not observed to vary seasonally. This finding is not surprising, as the average evapotranspiration (ET) rate in the New Jersey Pinelands is much lower $\left(22.5 \mathrm{in} / \mathrm{yr}\right.$, or $\left.5 \times 10^{-3} \mathrm{~cm} / \mathrm{hr}\right)$ than the observed infiltration rates (Rhodehamel, 1970). Most (10 of 15) initial infiltration rates in trench 1 were greater than the observed resting infiltration rates, indicating that wetting of initially drier unsaturated sediments accounts for a substantial portion of the observed infiltration. The same phenomenon likely occurred during pre-construction infiltration testing; a combination of lateral flow and wetting of initially drier sediments in the unsaturated zone were misinterpreted as steady-state vertical infiltration. Trenches 2 and 3 generally have resting infiltration rates greater than initial rates (10 of 17 and 7 of 9 , respectively), indicating that sediments underlying or adjacent to trenches 2 and 3 may have generally higher water contents (as a result of infiltrated and laterally flowing water from trench 1), which would act to slow infiltration. The relative altitude of the trench floors and the hydrostratigraphy of the site support this assertion. Trench 1 is the deepest of the trenches at $93.5 \mathrm{ft}$ above NAVD 88; the altitudes of the floors of trenches 2 and 3 are 98 and $100 \mathrm{ft}$ above NAVD 88, respectively. Trenches 1 and 2 both cut through a conductive sand (fig. 9b, zone G), which may permit lateral flow from trench 1 to increase the water content of sediments surrounding trench 2 . There is no direct hydrogeologic link between trenches 1 and 3 , but trenches 2 and 3 both cut through the shallowest conductive unit (fig. 7, zone H), which could provide a conduit for lateral flow between these two trenches.

Table 8. Infiltration and loading rates observed in (A) trench 1, (B) trench 2, and (C) trench 3, Hammonton Land Application Facility, southern New Jersey, 2002-07.

[Mgal, million gallons; in $/ \mathrm{hr}$, inches per hour; $\mathrm{cm} / \mathrm{hr}$, centimeters per hour; parentheses indicate negative values]

\begin{tabular}{|c|c|c|c|c|c|c|c|c|c|}
\hline \multirow{2}{*}{ A } & \multirow{2}{*}{ Begin date/time } & \multirow{2}{*}{ End date/time } & \multirow{2}{*}{$\begin{array}{l}\text { Load } \\
\text { (Mgal) }\end{array}$} & \multirow{2}{*}{$\begin{array}{c}\text { Infiltrated } \\
\text { volume, initial } \\
\text { (Mgal) }\end{array}$} & \multirow{2}{*}{$\begin{array}{c}\text { Infiltrated } \\
\text { volume, resting } \\
\text { (Mgal) }\end{array}$} & \multicolumn{2}{|c|}{$\begin{array}{l}\text { Initial infiltration } \\
\text { rate }\end{array}$} & \multicolumn{2}{|c|}{$\begin{array}{l}\text { Resting infiltration } \\
\text { rate }\end{array}$} \\
\hline & & & & & & (in/hr) & $(\mathrm{cm} / \mathrm{hr})$ & (in/hr) & (cm/hr) \\
\hline & 5/20/02 14:00 & 6/8/02 20:00 & 4.19 & 3.54 & 0.63 & 2.27 & 5.77 & 1.26 & 3.21 \\
\hline & 3/31/03 8:00 & 4/12/03 14:00 & 6.08 & 2.38 & .87 & .59 & 1.51 & .99 & 2.51 \\
\hline & 4/12/03 14:00 & 6/25/03 8:00 & 8.37 & 7.35 & 2.58 & 2.18 & 5.53 & .08 & .21 \\
\hline & 6/25/03 9:00 & 9/17/03 4:00 & 4.23 & 1.58 & 3.97 & .44 & 1.13 & .07 & .18 \\
\hline & 10/22/03 12:00 & 11/13/03 12:00 & 4.54 & 2.49 & 2.04 & .88 & 2.24 & .35 & .89 \\
\hline & 12/30/03 12:00 & 1/12/04 23:00 & 1.25 & $(.79)$ & .38 & $(.68)$ & $(1.72)$ & .57 & 1.45 \\
\hline & 3/16/04 9:00 & 6/28/04 0:00 & 1.43 & .08 & 1.44 & .22 & .57 & .05 & .13 \\
\hline & 11/1/04 14:00 & 12/2/04 23:00 & 7.84 & 3.54 & 3.93 & .54 & 1.37 & .23 & .59 \\
\hline & 12/27/04 8:00 & 1/31/05 23:00 & 4.91 & 1.90 & 3.01 & .54 & 1.36 & .18 & .47 \\
\hline & 3/7/05 8:00 & 5/18/05 16:00 & 7.02 & 2.71 & 4.32 & .47 & 1.19 & .08 & .20 \\
\hline & 10/23/06 11:00 & 11/19/06 11:00 & 5.47 & .98 & 4.50 & .16 & .42 & .26 & .66 \\
\hline & 1/22/07 15:00 & 3/15/07 14:00 & 5.35 & $(.39)$ & 5.49 & $(.05)$ & (.13) & .11 & .29 \\
\hline & 3/15/07 15:00 & 4/25/07 7:00 & 7.02 & .43 & 6.81 & .05 & .12 & .15 & .39 \\
\hline & 4/25/07 8:00 & 6/21/07 14:00 & 17.67 & 8.66 & 9.05 & .39 & .53 & .16 & .40 \\
\hline & 6/21/07 14:00 & 9/1/07 9:00 & 10.56 & 2.15 & 8.51 & .06 & .27 & .09 & .22 \\
\hline
\end{tabular}


Table 8. Infiltration and loading rates observed in (A) trench 1, (B) trench 2, and (C) trench 3, Hammonton Land Application Facility, southern New Jersey, 2002-07.-Continued

[Mgal, million gallons; in/hr, inches per hour; $\mathrm{cm} / \mathrm{hr}$, centimeters per hour; parentheses indicate negative values]

\begin{tabular}{|c|c|c|c|c|c|c|c|c|c|}
\hline \multirow[t]{2}{*}{ B } & \multirow{2}{*}{ Begin date/time } & \multirow{2}{*}{ End date/time } & \multirow{2}{*}{$\begin{array}{l}\text { Load } \\
\text { (Mgal) }\end{array}$} & \multirow{2}{*}{$\begin{array}{c}\text { Infiltrated } \\
\text { volume, initial } \\
\text { (Mgal) }\end{array}$} & \multirow{2}{*}{$\begin{array}{c}\text { Infiltrated } \\
\text { volume, resting } \\
\text { (Mgal) }\end{array}$} & \multicolumn{2}{|c|}{$\begin{array}{l}\text { Initial infiltration } \\
\text { rate }\end{array}$} & \multicolumn{2}{|c|}{$\begin{array}{l}\text { Resting infiltration } \\
\text { rate }\end{array}$} \\
\hline & & & & & & (in/hr) & $(\mathrm{cm} / \mathrm{hr})$ & (in/hr) & $(\mathrm{cm} / \mathrm{hr})$ \\
\hline & $3 / 24 / 200323: 00$ & 5/14/2003 2:00 & 3.07 & 0.08 & 3.05 & 0.02 & 0.05 & 0.09 & 0.22 \\
\hline & 5/14/2003 8:00 & 6/3/2003 1:00 & 4.19 & .14 & .97 & .02 & .05 & .29 & .73 \\
\hline & 6/3/2003 2:00 & 7/21/2003 23:00 & 2.39 & .47 & 4.87 & .23 & .59 & .10 & .25 \\
\hline & 7/21/2003 12:00 & 8/14/2003 2:00 & 4.59 & 1.14 & 1.40 & .20 & .50 & .23 & .58 \\
\hline & 9/17/2003 8:00 & 11/7/2003 9:00 & 4.01 & 1.07 & 5.45 & .20 & .51 & .09 & .22 \\
\hline & 2/9/2004 10:00 & $3 / 24 / 200414: 00$ & 2.51 & $(.02)$ & 2.55 & $(.01)$ & $(.03)$ & .09 & .24 \\
\hline & 5/26/2004 9:00 & 6/25/2004 0:00 & 2.98 & (.44) & 3.42 & $(.16)$ & $(.41)$ & .14 & .35 \\
\hline & 8/13/2004 10:00 & 9/14/2004 12:00 & 4.28 & 1.85 & 2.42 & .41 & 1.04 & .16 & .40 \\
\hline & 9/27/2004 8:00 & 11/14/2004 11:00 & 5.50 & .66 & 4.84 & .07 & .19 & .09 & .24 \\
\hline & 11/22/2004 8:00 & $1 / 18 / 200516: 00$ & 3.94 & .53 & 3.41 & .08 & .21 & .12 & .31 \\
\hline & 1/31/2005 8:00 & 4/5/2005 23:00 & 4.11 & .94 & 2.91 & .17 & .44 & .07 & .17 \\
\hline & 1/19/2006 11:00 & 4/3/2006 8:00 & 5.03 & 1.92 & 3.08 & .33 & .85 & .06 & .14 \\
\hline & 4/3/2006 11:00 & $5 / 18 / 2006$ 10:00 & 4.25 & .93 & 1.79 & .18 & .46 & .10 & .26 \\
\hline & 5/18/2006 11:00 & 7/11/2006 10:00 & 5.30 & 2.52 & 4.32 & .40 & 1.02 & .09 & .22 \\
\hline & 9/25/2006 8:00 & 11/29/2006 13:00 & 5.00 & $(.04)$ & 4.36 & $(.003)$ & $(.01)$ & .07 & .17 \\
\hline & 11/29/2006 14:00 & 1/19/2007 10:00 & 3.05 & .26 & 2.53 & .07 & .17 & .08 & .21 \\
\hline & 2/26/2007 8:00 & $6 / 2 / 2007$ 16:00 & 4.37 & .17 & 4.47 & .02 & .06 & .04 & .11 \\
\hline
\end{tabular}

\begin{tabular}{|c|c|c|c|c|c|c|c|c|c|}
\hline \multirow[t]{2}{*}{ C } & \multirow{2}{*}{ Begin date/time } & \multirow{2}{*}{ End date/time } & \multirow{2}{*}{$\begin{array}{l}\text { Load } \\
\text { (Mgal) }\end{array}$} & \multirow{2}{*}{$\begin{array}{c}\text { Infiltrated } \\
\text { volume, initial } \\
\text { (Mgal) }\end{array}$} & \multirow{2}{*}{$\begin{array}{c}\text { Infiltrated } \\
\text { volume, resting } \\
\text { (Mgal) }\end{array}$} & \multicolumn{2}{|c|}{$\begin{array}{l}\text { Initial infiltration } \\
\text { rate }\end{array}$} & \multicolumn{2}{|c|}{$\begin{array}{l}\text { Resting infiltration } \\
\text { rate }\end{array}$} \\
\hline & & & & & & (in/hr) & $(\mathrm{cm} / \mathrm{hr})$ & (in/hr) & $(\mathrm{cm} / \mathrm{hr})$ \\
\hline & 6/3/2002 8:00 & 7/3/2002 11:00 & 3.18 & $(0.14)$ & 3.23 & $(0.04)$ & $(0.09)$ & 0.17 & 0.44 \\
\hline & 10/2/2003 9:00 & $11 / 13 / 200314: 00$ & 4.41 & 1.07 & 2.93 & .17 & .44 & .14 & .35 \\
\hline & 10/7/2005 16:00 & 12/8/2005 8:00 & 2.73 & $(.40)$ & 2.95 & $(.08)$ & $(.21)$ & .12 & .31 \\
\hline & 2/8/2006 0:00 & $4 / 13 / 2006$ 13:00 & 2.67 & .10 & 3.21 & .03 & .07 & .07 & .19 \\
\hline & 4/13/2006 14:00 & 5/30/2006 8:00 & 3.10 & .16 & 2.48 & .04 & .09 & .11 & .28 \\
\hline & 5/30/2006 9:00 & 6/15/2006 12:00 & 1.84 & .17 & .48 & .13 & .32 & .35 & .88 \\
\hline & 6/15/2006 8:00 & 8/4/2006 10:00 & 0.67 & $(.22)$ & 1.67 & (1.58) & $(4.02)$ & .09 & .23 \\
\hline & 8/4/2006 15:00 & $12 / 31 / 200623: 00$ & 1.14 & .12 & .84 & .24 & .60 & .03 & .08 \\
\hline & 1/18/2007 12:00 & $7 / 28 / 200713: 00$ & 1.97 & .03 & 3.39 & .02 & .04 & .02 & .06 \\
\hline
\end{tabular}




\section{Trench Wall Collapse and Infilling}

ARH Associates (1993) designed the trench bottoms to be between 87 and $105 \mathrm{ft}$ above NAVD 88 to "maintain at least $15 \mathrm{ft}$ to ground water below the basin and to avoid the slowly permeable strata identified on portions of the site at elevations 105 to $110 \mathrm{ft}$ above mean sea level (AMSL)." Pennoni Associates (1999), in the final plans for the design of the facility, report that the altitude of the trench 1 floor was planned to be $97 \mathrm{ft}$ AMSL. After initial excavation, Pennoni Associates (written commun., 2001) excavated test pits within each trench and conducted subsurface sediment observations. They reported approximately $15 \mathrm{in}$. of compaction in trenches 1 to 3 and attributed it to the operation of excavation equipment within the trenches during their construction. Test pits within trench 1 revealed iron pans and poorly conductive sediments from 0 to 63 in. below the floor of trench 1, with most of the restrictive materials located between 0 and 36 in. below the trench floor. Pennoni Associates (written commun., 2001) recommended increasing the depth of trench 1 by $3 \mathrm{ft}$ to bypass these poorly conductive sediments. After this time, operation of the facility began and soon thereafter trench 1 was not meeting performance requirements. Pennoni Associates (2003) excavated pits within trench 1 to determine whether sediments had been degraded during the operation of the facility. Subsurface sediment observations were compared to prior descriptions (Pennoni Associates, written commun., 2001). They found a 0.5 - to 2 -in. layer of "consolidated fine soil materials which appears to be the primary cause for the lack of infiltration in this trench" and compacted soils from 2 to 6 in. below the floor of the trench. The generation of compacted soils was attributed to the weight of the treated effluent bearing down upon the consolidated fine soil material for prolonged periods. No evidence of the formation of restrictive layers by means of iron cementation or other chemical alteration below 6 in. was reported. Pennoni Associates (2003) recommended removal of 6 in. of material from the floor of trench 1 (making the altitude of the floor of the trench $93.5 \mathrm{ft}$ ) followed by a deep tining and ripping to "recondition the surface layers and to eliminate any surface compaction which may have occurred during the stripping operation."

The USGS conducted a survey across trench 1 on December 20, 2006, to determine whether infilling or slumping of trench walls had occurred (figs. 19 and $20 \mathrm{a}-\mathrm{d}$ ). Trench 1 is the deepest of the trenches at the Hammonton LAF $(14.5 \mathrm{ft})$ and the only one in which wall failure and infilling were suspected to be contributing to poor infiltration. Cross section $G-G^{\prime}$ (fig. 20a) is $130 \mathrm{ft}$ long, was developed from 34 altitude measurements, and is characterized by a " $U$ "-shaped geometry. The lowest altitude in the approximately 58 -ft-wide trench floor in cross section $G-G$ ' was $93.95 \mathrm{ft}$. If the assumption is made that the design base level of $93.5 \mathrm{ft}$ was attained, then $0.45 \mathrm{ft}$ of sediment has accumulated in this portion of trench 1 since 2003.

Cross section $H-H^{\prime}$ ' (fig. 20b) and $I-I^{\prime}$ (fig. 20c) are 141 and $137 \mathrm{ft}$ long and were constructed from 49 and 51 altitude measurements, respectively. Both cross sections are asymmetrical such that the slope of the southwestern trench wall is less steep than that of the northeastern wall, and the lowest point in the trench is off-center. In both cross sections $H-H^{\prime}$ (fig. 20b) and $I-I^{\prime}$ (fig. 20c) 6-ft portions of the trench bottom are slightly lower than $93.5 \mathrm{ft}$ above NAVD 88, which indicates either that both trenches were excavated deeper than designed, or that floor sediments have been eroded. Although altitudes of portions of the trench bottom are similar to those reported in 2003 (Pennoni Associates, 2003), the irregular shape of trench 1 in the vicinity of these cross sections indicates that some slumping of the southwestern trench wall may have occurred. Final construction plans (Pennoni Associates, 2003) indicate that a typical 70-ft-wide floor and 3:1 slopes on both the southwestern and northeastern walls were designed. The precise degree of wall deterioration is impossible to determine, as "as-built" schematic diagrams were not archived for any of the trenches.

Cross section $J-J$ ' (fig. 20d) is $129 \mathrm{ft}$ long, was constructed from 49 altitude measurements, and is characterized by a "U"-shaped geometry similar to that of cross section $G-G$ ' (fig. 20a). Most of the approximately 40 -ft-wide trench floor is lower than $93.5 \mathrm{ft}$ above NAVD 88. As was the case with the other cross sections, this finding indicates that trenches were excavated slightly deeper than designed or that sediment had eroded since 2003.

Incised erosional channels in the western trench wall (fig. 21) and other areas indicate that inflow of surface runoff contributes to sediment transport from the trench walls to the floor. All cross sections show some post-construction alteration but, because "as-built" construction data and diagrams are unavailable, quantification of the actual amount of infilling and trench-wall deterioration is impossible.

\section{Comparisons to other Pinelands Land Application Facilities}

Evaluation of the hydrogeology at the Hammonton LAF indicates that commonly occurring strata with poor hydraulic conductivity within the unsaturated zone underlying the trenches are responsible for the poor infiltration rates. To determine whether these conditions are unique to the Hammonton LAF, HPT testing was conducted at the Landis and Sicklerville LAFs and at Aero Haven, the site of a planned LAF for the Evesham Township Municipal Utilities Authority. Testing at the Landis and Sicklerville LAFs was conducted within basins that are in service but were dry on the day of the site visit; the testing location at Aero Haven was adjacent to an existing monitoring well near the entrance to the property. Managers of the Landis and Sicklerville LAFs indicate that their facilities are performing as designed. HPT testing results support this assertion, as flow rates never fell below $200 \mathrm{~mL} / \mathrm{min}$ and no increases in pressure were noted during testing at the Sicklerville, Landis, or Aero Haven site (fig. 22). These results indicate that these current and proposed 


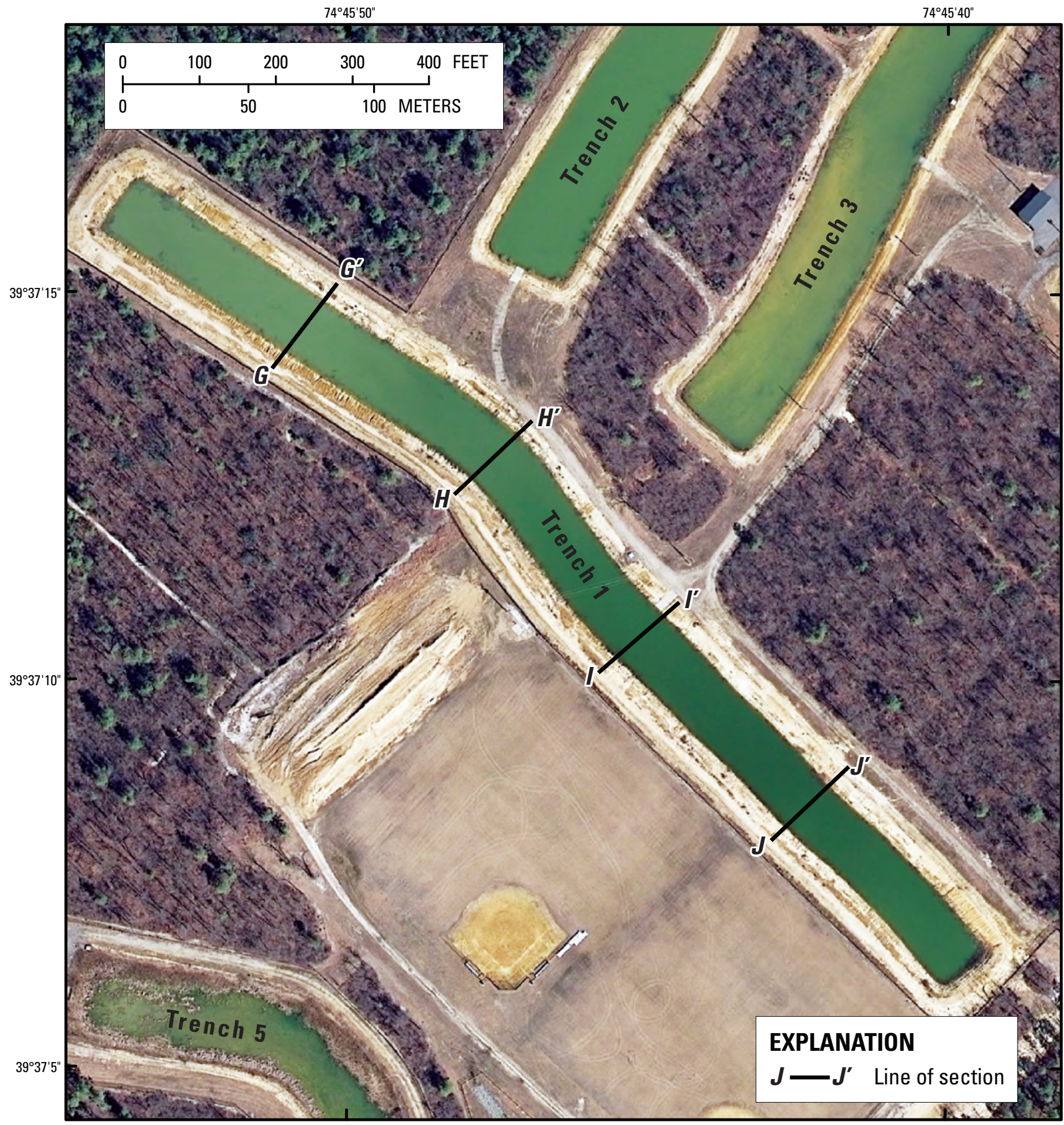

Orthophoto from New Jersey Office of Information Technology, Office of Geographic Information Systems, 2008

Figure 19. Lines of section across trench 1 along which land-surface altitudes were measured, Hammonton Land Application Facility, southern New Jersey. 


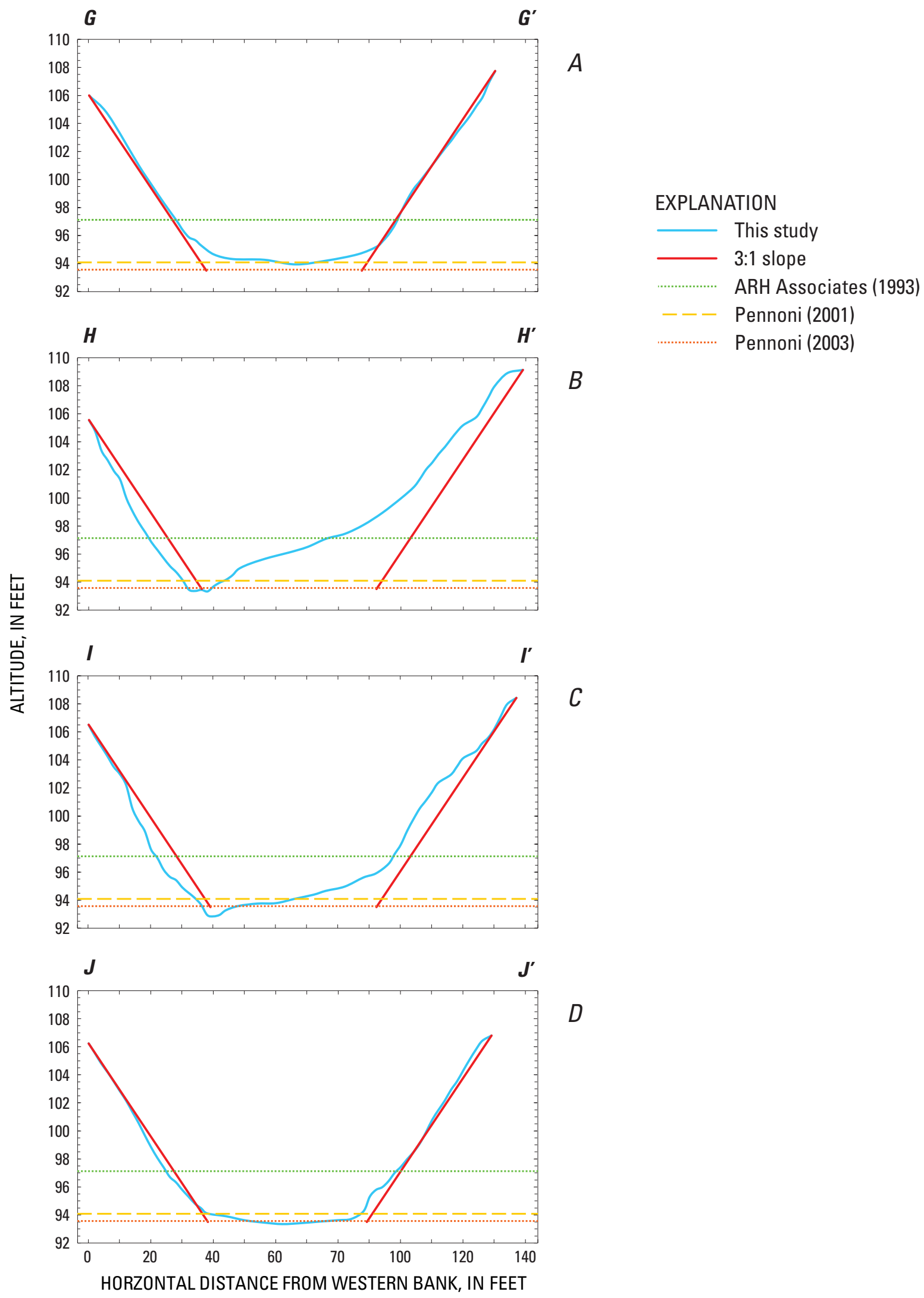

Figure 20. Vertical profiles across trench 1 showing land-surface altitudes along sections $(A) G-G^{\prime},(B) H-H^{\prime},(C) I-I^{\prime}$, and $(D) J-J^{\prime}$, Hammonton Land Application Facility, southern New Jersey. 


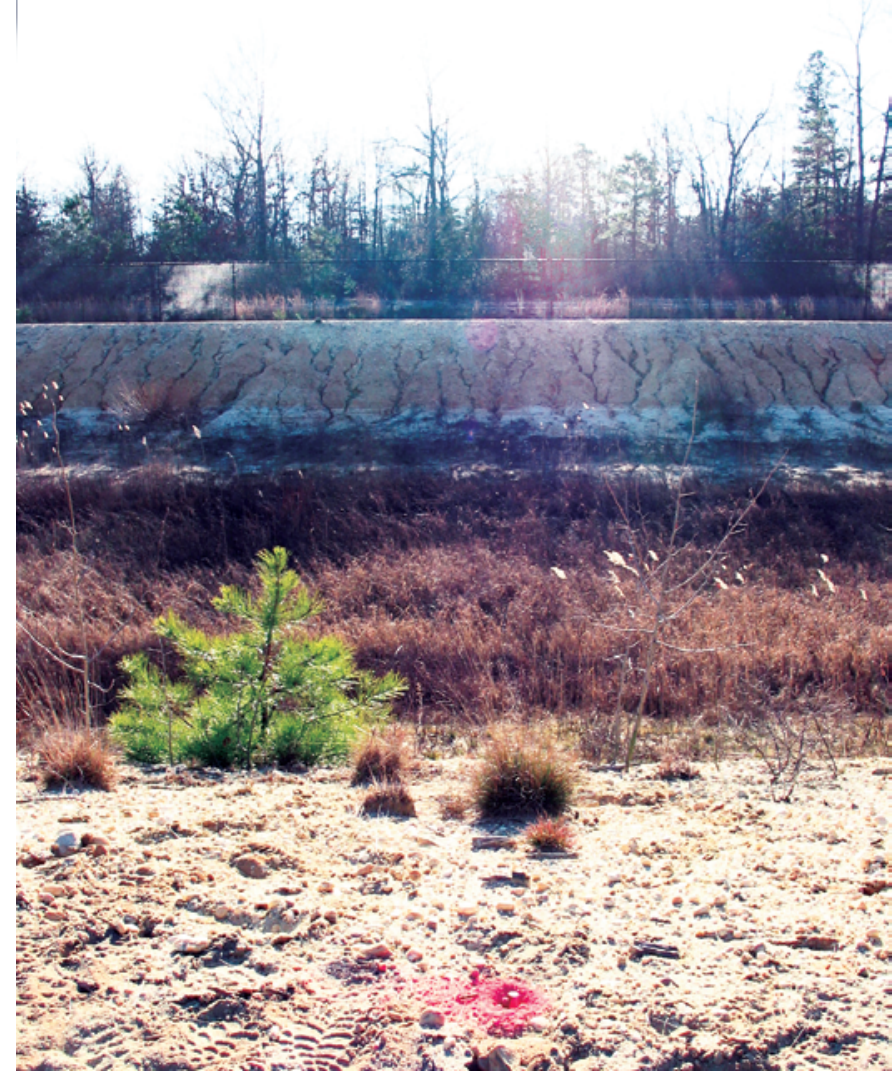

Figure 21. Erosional features of the southern wall of trench 1, Hammonton Land Application Facility, southern New Jersey.

facilities are not underlain by strata that restrict flow. Although both the Sicklerville and Hammonton LAFs are underlain by the Bridgeton Formation, the HPT results indicate no impediments to infiltration at Sicklerville, a condition due, at least in part, to maintenance regimes at Sicklerville that call for the periodic excavation of trenches to a depth of up to $12 \mathrm{ft}$ below the current trench-floor altitude. Excavated sediments are removed and replaced with clean sand. Variations in the grain size of the Bridgeton Formation based on differences in the depositional and erosional history of the unit between Hammonton and Sicklerville also must contribute to the difference in hydraulic properties. The Landis LAF is underlain by Lower Terrace deposits, which consist of gravels that, on the basis of HPT testing, have nearly uniform hydraulic properties with no restrictive strata. HPT results for Aero Haven are similar to those for the Landis and Sicklerville LAFs. This is not surprising, as the site is underlain by the sand and pebble gravels of Upper Terrace and weathered Coastal Plain deposits of similar parent material. Although a more comprehensive site investigation prior to siting infiltration trenches is warranted, these results indicate that the sediment underlying Aero Haven contains no layer that would impede infiltration of treated wastewater.

Collapse of wall materials and (or) accumulation of sediment may contribute to the performance issues observed at the Hammonton LAF. No collapse features were observed at facilities other than the Hammonton LAF. The trench-wall slopes at the Landis and Sicklerville LAFs are shallower than those at the Hammonton LAF; steeper slopes are more vulnerable to collapse. As the trench drains, the trench-wall sediments retain residual water, making them heavier and decreasing sediment cohesion (reducing the effective angle of repose for the sediment in the wall). If the cohesion of sediments is reduced such that the sheer strength of the wall is exceeded, sediment will move downslope. The accumulations of sediment and slumping of trench walls at the Hammonton LAF appear to be evidence of this process.

Because hourly flow and gage-height data are not available for facilities other than the Hammonton LAF, detailed comparisons of initial and resting infiltration rates are impossible. Average loading rates and infiltration-basin areas are available for the Sicklerville and Landis LAFs. During winter months (November-February), an average of 5.6 Mgal/d infiltrates over 140 acres of basins at the Landis LAF (Dennis Palmer, Landis LAF, oral commun., 2009). Of the 140 acres, only a small portion (12-32 acres) is in use at any given time, allowing for an ample resting period (Dennis Palmer, Landis LAF, oral commun., 2009). Dividing the mean daily flow by the area of the infiltration basins yields an average winter infiltration rate for the Landis LAF of $0.43 \mathrm{in} / \mathrm{hr}(1.1 \mathrm{~cm} / \mathrm{hr})$. In dry weather, an average of $2 \mathrm{Mgal} / \mathrm{d}$ of wastewater is treated and applied over 52.3 acres of basins at the Sicklerville LAF (Andrew Kricum, Camden County Municipal Utilities Authority, oral commun., 2009). At any given time, approximately 80 percent of the Sicklerville recharge basins are in service and 20 percent are "resting" (Andrew Kricum, oral commun., 2009). Therefore, the Sicklerville LAF has an average infiltration rate of $0.08 \mathrm{in} / \mathrm{hr}(0.2 \mathrm{~cm} / \mathrm{hr})$. Although a higher infiltration rate is achieved at the Hammonton LAF than at the Sicklerville LAF, wastewater at the Hammonton LAF is applied to only 15.3 acres of trenches (ARH Associates, 1993). Average infiltration rates determined from pre-construction infiltration tests conducted at the Hammonton LAF are nearly 20 times greater than the average rate observed at the Landis LAF.

Attempts to correlate the geology at the study sites with the most refined maps of geology or soils available were only partially successful. In general, the mapped units indicate the deposits present in the vicinity of the site, but the geologic characteristics of the individual sites vary considerably, as would be expected for materials deposited in a fluvial environment. The composition of any given unit can vary considerably with location. 
SICKLERVILLE LAF

LANDIS LAF

MAXIMUM PRESSURE, IN POUNDS PER SQUARE INCH
HAMMONTON LAF NEST 11 MW C
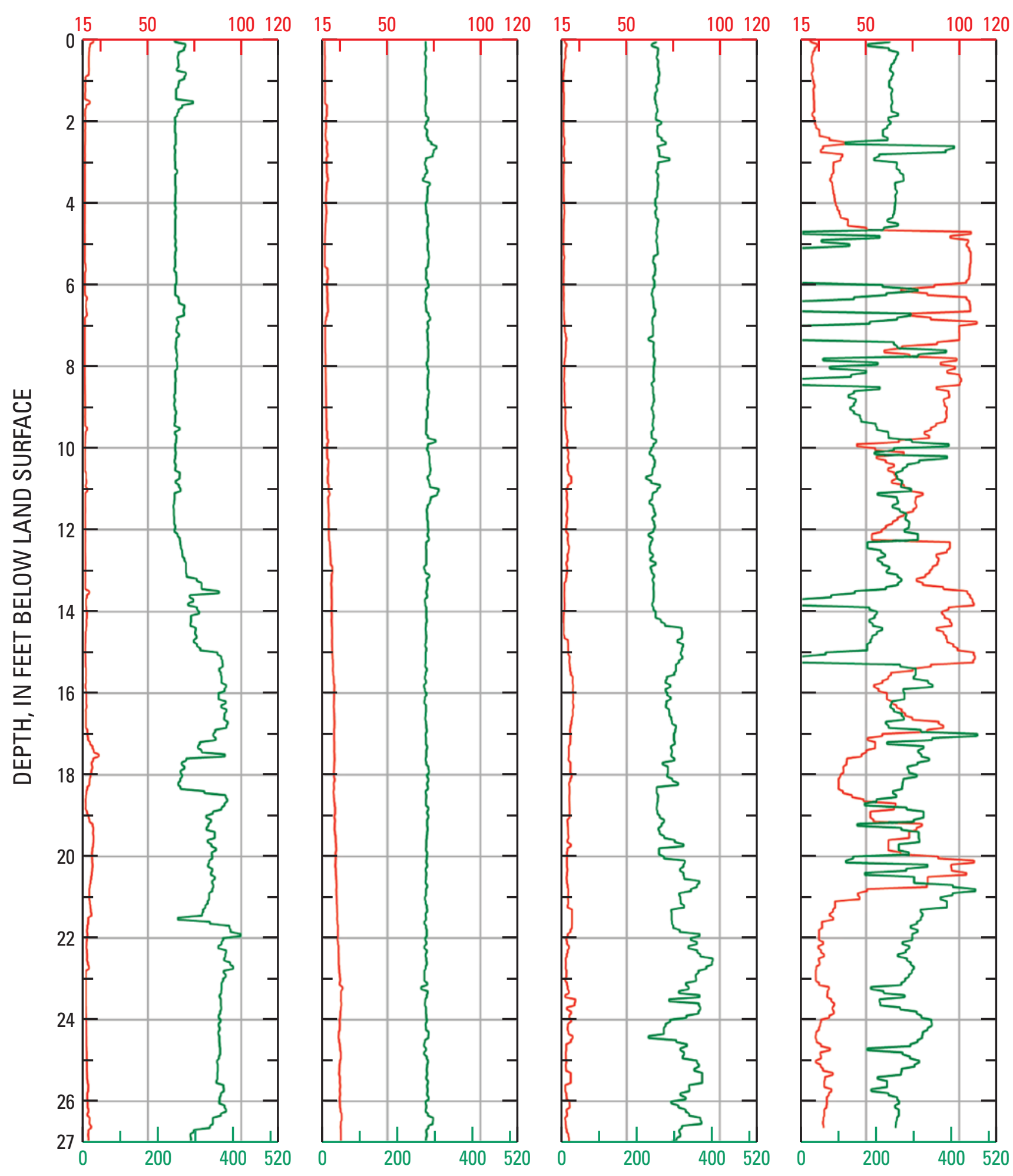

MAXIMUM FLOW, IN MILLILITERS PER MINUTE

Figure 22. Comparison of results of Hydraulic Profiling Tool tests conducted at selected existing and proposed land application facilities (LAFs) in southern New Jersey. 


\section{Summary and Conclusions}

In 1991, the New Jersey Department of Environmental Protection (NJDEP) directed the Town of Hammonton to upgrade its sewage-treatment plant and cease stream discharge to meet Pinelands and New Jersey Pollutant Discharge Elimination System (NJPDES) requirements. In response to the NJDEP directive, Hammonton constructed a new tertiary-treatment plant and land application facility (LAF). In its second year of operation (2002), the LAF was found to be capable of infiltrating a maximum of $0.6 \mathrm{Mgal} / \mathrm{d}$, far less than the design capacity of $1.6 \mathrm{Mgal} / \mathrm{d}$. Because anticipated development in Hammonton and other Pinelands towns will require construction of additional infiltration facilities or use of alternative methods to treat and dispose of treated wastewater, the U.S. Geological Survey, in cooperation with the Pinelands Commission and the Town of Hammonton, New Jersey, conducted a study to identify potential reasons for the reduced infiltration in the trenches at the Hammonton LAF and assess the potential for similar conditions to exist elsewhere in the New Jersey Coastal Plain, particularly within the Pinelands National Reserve, by collecting and analyzing sediment, geophysical, water-quality, water-level, flow, altitude, and operational data.

Multiple lines of evidence indicate that aerially extensive fine-grained and (or) iron-cemented strata underlying the Hammonton LAF impede infiltration and cause lateral flow and perching of water. Gamma logs from wells, HPT drivepoint testing, and sediment cores indicate the presence of numerous low-permeability layers in the subsurface throughout the facility. Low-permeability layers vary in thickness from less than $1 \mathrm{ft}$ to approximately $5 \mathrm{ft}$. Some layers were detected as deep as $30 \mathrm{ft}$ below the land surface. An interpretation of the geophysical data indicates that many of these layers are continuous beneath the site. Auger holes and piezometer water-level measurements indicate the presence of at least three zones of perched water beneath the trenches. Results of chemical analyses of perched-water samples indicate that the source of the water is primarily infiltrated wastewater.

Performance of the Hammonton LAF trenches has changed since operations began in 2002. From 2002 to 2007, infiltration rates in trench 1 have declined whereas those in trenches 2 and 3 have remained relatively stable. The initially high infiltration rates in trench 1 are interpreted to result from the filling of initially dry pore spaces at the site. Once these voids were filled, the infiltration rate reflected the limitations imposed by the low-permeability layers. After a brief period of relatively high infiltration rates, the average initial and resting infiltration rates for all three trenches dropped to 0.56 and $0.18 \mathrm{in} / \mathrm{hr}(0.47 \mathrm{~cm} / \mathrm{hr})$, respectively. In 7 of the 41 infiltration events evaluated, each of the trenches gained more water than expected during loading on at least two occasions. This observation, combined with the presence of the low-permeability layers and perched water, most likely indicates that lateral flow between trenches is occurring through zones of perched water. Because of these subsurface interconnections, filling of any one trench can affect the performance of nearby trenches and likely increases the time needed for the subsurface to drain between trench fillings. Differences between initial and resting infiltration rates indicates that wetting of initially drier unsaturated sediments accounts for a substantial portion of the observed infiltration. Once the pore spaces were filled, the infiltration rates decreased. The same phenomenon likely occurred during pre-construction infiltration testing, as infiltration-test results overestimated average operational infiltration rates by a factor of 40 . Infiltration tests that were assumed to observe steady-state vertical infiltration were in all likelihood the result of a combination of lateral flow and wetting of initially drier sediments in the unsaturated zone. Similar analyses at other LAFs in southern New Jersey show similar rates of infiltration. Higher volumes of treated wastewater infiltrate at other LAFs than at the Hammonton LAF because the basin area over which the water is applied is greater and the underlying geology is more hydraulically conductive.

Altitude surveys of trench 1 show that slumping and redeposition of wall sediments has occurred, but the magnitude of the effect of this process on infiltration rates is unclear. Contributing to the wall instability is the possibility that, when saturated or submerged, the sediments underlying the Hammonton LAF have an angle of repose shallower than the 3:1 slope of the walls. Trench 1, the deepest infiltration trench at any of the sites studied, was the only trench at which evidence of this process was noted.

Infiltration at the Hammonton LAF is controlled primarily by the low-permeability strata at the site; therefore, any attempt to increase infiltration must account for the characteristics of the geologic materials underlying the site. Removing the layers beneath trench 1 would require excavating $20 \mathrm{ft}$ below the current floor to remove and replace approximately $1.5 \times 10^{6} \mathrm{ft}^{3}$ of sediment. Routine perched-water or soilmoisture monitoring to adjust loading levels and the duration of resting periods at the site would help to reduce interactions between trenches. The infiltration rate of water applied elsewhere at the site is likely to be affected by the possible occurrence of perching and interactions between recharge areas. A routine program of trench maintenance and wall stabilization might improve performance at trench 1 , as long as stabilization is conducted in a manner that does not reduce the permeability of the trench walls.

Although infiltration at the Hammonton LAF is impeded by low-permeability strata, analyses of water-quality samples characteristic of treated wastewater in monitoring wells, temporary drive points, and perched water indicates that water from the facility is reaching the underlying aquifer. Long holding times within the storage lagoon and a lengthy recharge path provide opportunities for sorption, dilution, and biodegradation of many wastewater constituents, resulting in minimal effects on the aquifer from nutrients and wastewater compounds. Concentrations of nitrate in samples of shallow groundwater underlying the facility are lower than those observed in perimeter monitoring wells that capture water from other regional sources of nutrients. 
The performance of potential future infiltration sites in the Pinelands can be maximized by the consideration of sitespecific, three-dimensional hydrogeologic information when evaluating potential sites. Regional- and local-scale geologic information available from maps and previously published reports lacks the precision needed for selecting infiltration sites in the Pinelands. Even detailed maps of local surficial geology, soils, and runoff potential at the 1:24,000 scale are of limited use when selecting infiltration sites, because the scale of local variations in sediment hydrogeologic properties is below the resolution of the map. Results of groundwater simulations and slug tests typically provide information about the large-scale average horizontal permeability of deeper sediments rather than the small-scale vertical permeability of nearsurface unsaturated sediments that can impede infiltration.

Designers and builders of future wastewater infiltration facilities in southern New Jersey and similar hydrogeologic settings can benefit from the investigation of the problems encountered at the Hammonton LAF and the experiences of its operators. Rigorous characterization of the grain size and stratigraphy of units underlying prospective infiltration trenches prior to construction (ideally as part of the site-selection and land-acquisition process) will help to ensure the success of future facilities. Because the unsaturated conductivity of sediments underlying infiltration trenches dramatically affects site performance, including this characteristic as a site-selection criterion for future facilities is essential. Results of infiltration testing can be misleading and may not be a good predictor of long-term performance. If infiltration tests are conducted, installation of soil-moisture monitoring equipment may be necessary to rule out the possibility of lateral flow. With the advent of tools like the HPT that can measure hydraulic properties directly, it is possible to use direct-drive equipment (verified with samples of continuous sediment cores) to collect dense hydrogeologic data rapidly. The HPT allows identification of hydraulically restrictive units that could go unnoticed with surface-based infiltration testing.

\section{Acknowledgments}

The authors thank Anthony DeCicco (Town of Hammonton) and Edward Wengrowski, Lawrence Liggett, and Thomas Stanuikynas (New Jersey Pinelands Commission) for their support and cooperation. We also thank Joseph Pantalone (Adams, Rehmann \& Heggan Associates) and Seth Gladstone (Pennoni Associates Inc.) for ready access to their archived data and engineering reports. The authors thank Eric Best, Lawrence Feinson, Robert Rosman, Jason Shvanda, and Nicholas Smith of the USGS for their diligent field efforts. We are indebted to Arthur Baehr (USGS) for his insightful suggestions throughout this effort, to Donald Rice (USGS) for preparation of GIS-based figures, and to Pierre Lacombe and Paul Stackelberg (USGS) for their thorough reviews, which greatly improved this manuscript.

\section{References Cited}

ARH Associates, 1989, Town of Hammonton, Atlantic County, Wastewater Management Plan: Hammonton, New Jersey, May 1989, revised August 1, 1989, and October 10, 1989, $10 \mathrm{p}$.

ARH Associates, 1993, Hammonton Wastewater Treatment Plant Land Application Facility final report: Hammonton, New Jersey, $91 \mathrm{p}$.

Brenton, R.W., and Arnett, T.L., 1993, Methods of analysis by the U.S. Geological Survey National Water Quality Laboratory-Determination of dissolved organic carbon by UV-promoted persulfate oxidation and infrared spectrometry: U.S. Geological Survey Open-File Report 92-480, 12 p.

Burkhardt, M.R., ReVellow, R.C., Smith, S.G., and Zaugg, S.D., 2005, Pressurized liquid extraction using water/isopropanol coupled with solid-phase extraction cleanup for industrial and anthropogenic waste-indicator compounds in sediment: Analytica Chimica Acta, v. 534, p. 89-100.

Chemicalland21.com, Triethyl citrate, 2009, accessed September 3, 2009, at http://chemicalland21.com/specialtychem/ perchem/TRIETHYL\%20CITRATE.htm.

Childress, Carolyn J. O., Foreman, W.T., Connor, B.F., and Maloney, T.J., 1999, New reporting procedures based on long-term method detection levels and some considerations for interpretations of water-quality data provided by the U.S. Geological Survey National Water Quality Laboratory: U.S. Geological Survey Open-File Report 99-193, 25 p.

Fetter, C.W., 1984, Applied hydrology, 3d ed.: New York, Macmillan College Publishing Company, 691 p.

Fishman, M.J., and Friedman, L.C., 1989, Methods of determination of inorganic substances in water and fluvial sediments: U.S. Geological Survey Techniques of WaterResources Investigations, book 5, chap. A1, 545 p.

Fishman, M.J., ed., 1993, Methods of analysis by the U.S. Geological Survey National Water Quality LaboratoryDetermination of inorganic and organic constituents in water and fluvial sediments: U.S. Geological Survey OpenFile Report 93-125, 217 p.

Garbarino, J.R., and Damrau, D.L., 2001, Methods of analysis by the U.S. Geolgoical Survey National Water Quality Laboratory-Determination of organic plus inorganic mercury in filtered and unfiltered natural water with cold vaporatomic fluorescence spectrometry: U.S. Geological Survey Water-Resources Investigations Report 01-4132, 16 p. 
Garbarino, J.R., Kanagy, L.K., and Cree, M.E., 2006 Determination of elements in natural-water, biota, sediment and soil samples using collision/reaction cell inductively coupled plasma-mass spectrometry: U.S. Geological Survey Techniques and Methods, book 5, sec. b, chap. 1, 88 p.

Geoprobe Systems, 1998, Geoprobe Macro-Core ${ }^{\circledR}$ Hydraulic Soil Sampler standard operating procedure: Technical Bulletin No. 95-8500, 27 p.

Geoprobe Systems, 2007, Geoprobe ${ }^{\circledR}$ Hydraulic Profiling Tool (HPT) standard operating procedure: Technical Bulletin No. MK3137, 19 p., accessed September 3, 2009, at http://geoprobe-di.com/component/option,com_remository/ Itemid,80/func,select/id, $8 /$.

Hem, John D., 1992, Study and interpretation of the chemical characteristics of natural water, $3 d$ ed.: U.S. Geological Survey Water-Supply Paper 2254, 264 p.

Hinkle, S.R., Weick, R.J., Johnson, J.M., Cahill, J.D., Smith, S.G. and Rich, B.J., 2005, Organic wastewater compounds, pharmaceuticals, and coliphage in ground water receiving discharge from onsite wastewater treatment systems near La Pine, Oregon-Occurrence and implications for transport: U.S. Geological Survey Scientific Investigations Report 2005-5055, 98 p.

Kennedy, E.J., 1990, Levels at streamflow gaging stations: Techniques of Water-Resources Investigations of the United States Geological Survey, book 3, chap. A19, 30 p.

Keys, W.S., and McCary, L.M., 1971, Application of borehole geophysics to water-resources investigations: U.S. Geological Survey Techniques of Water-Resources Investigations, book 2, chap. E1, 126 p.

Munsell ${ }^{\mathrm{TM}}$ Color, 2000, Munsell ${ }^{\mathrm{TM}}$ soil color charts: New Windsor, NY, GretagMacbeth, year 2000 revised washable edition.

National Toxicology Program, 1989, NTP toxicology and carcinogenesis studies of tribromomethane (bromoform) (CAS No. 75-25-2) in F344/N rats and B6C3F1 mice (gavage studies): National Toxicology Program Technical Report $321,194 \mathrm{p}$.

New Jersey Pinelands Commission, 2007, New Jersey Pinelands Commission, accessed August 10, 2009, at http://www.state.nj.us/pinelands/.

Newell, W.L., Powars, D.S., Owens, J.P., Stanford, S.D., and Stone, B.D., 2000, Surficial geologic map of central and southern New Jersey: U.S. Geological Survey Miscellaneous Investigations Map I-2540-D, scale 1:100,000.
Owens, J.P., Hess, M.M., Denny, C.S., and Dwornik, E.J., 1983, Postdepositional alteration of surface and near-surface minerals in selected Coastal Plain formations of the Middle Atlantic States: U.S. Geological Survey Professional Paper 1067-F, 45 p.

Patton, C.J., and Truitt, E.P., 1992, Methods of analysis by the U.S. Geological Survey National Water Quality Laboratory-Determination of total phosphorus by a Kjeldahl digestion method and an automated colorimetric finish that includes dialysis: U.S. Geological Survey Open-File Report 92-146, 39 p.

Patton, C.J., and Truitt, E.P., 2000, Methods of analysis by the U.S. Geological Survey National Water Quality Laboratory-Determination of ammonium plus organic nitrogen by a Kjeldahl digestion method and an automated photometric finish that includes digest cleanup by gas diffusion: U.S. Geological Survey Open-File Report 00-170, 31 p.

Pennoni Associates Inc., 1999, Boyer Avenue land application project: Absecon, N.J., Pennoni Associates Inc., prepared for Town of Hammonton, May 1999, 23 sheets.

Pennoni Associates Inc., 2003, Slit trench 1 sub-soil investigation report: Absecon, N.J., Pennoni Associates Inc., prepared for Town of Hammonton, October 17, 2003.

Rhodehamel, E.C., 1970, A hydrologic analysis of the New Jersey Pine barrens region: Trenton, N.J., New Jersey Department of Environmental Protection, Division of Water Policy and Supply, Water Resources Circular 22, 40 p.

Sanchez-Prado, L., Llompart, M., Lores, M., García-Jares, D., Bayon, J.M., and Cela, R., 2006, Monitoring the photochemical degradation of triclosan in wastewater by UV light and sunlight using solid-phase microextraction: Chemosphere, v. 65 , p. $1,338-1,347$.

Soil Survey Division Staff, 1993, Soil survey manual: Soil Conservation Service, U.S. Department of Agriculture Handbook 18, accessed September 8, 2009, at http://soils.usda.gov/technical/manual/.

Struzeski, T.M., DeGiacomo, W.J., and Zayhowski, E.J., 1996, Methods of analysis by the U.S. Geological Survey National Water Quality Laboratory-Determination of dissolved aluminum and boron in water by inductively coupled plasma-atomic emission spectrometry: U.S. Geological Survey Open-File Report 96-149, 17 p.

U.S. Geological Survey, Branch of Quality Systems, 2009 Blind Blank Project: accessed March 3, 2009, at http://bqs.usgs.gov/bbp. 
U.S. Environmental Protection Agency, 2007, Technology transfer network air toxics website, Bis(2-ethylhexyl) phthalate (DEHP): accessed September 3, 2009, at http://www.epa.gov/ttn/atw/hlthef/eth-phth.html.

U.S. Environmental Protection Agency, 2009a, Pesticides: Topical \& chemical fact sheets-The insect repellant DEET: accessed September 3, 2009, at http://www.epa.gov/ pesticides/factsheets/chemicals/deet.htm.

Wilde, F.D., and Radtke, D.B., eds., 1998, National field manual for the collection of water-quality data: U.S. Geological Survey Techniques of Water-Resources Investigations, book 9, chap. A6, 233 p.

Xu, B., Gao, N., Sun, X., Xia, S., Rui, M., Simonnot, M., Causserand, C., and Zhao, J., 2007, Photochemical degradation of diethyl phthalate with UV/H2O2: Journal of Hazardous Materials, v. 139, p. 132-139.

Zapecza, O.S., 1989, Hydrogeologic framework of the New Jersey Coastal Plain: U.S. Geological Survey Professional Paper 1404-B, 49 p., 24 pl.

Zaugg, S.D., Smith, S.G., and Schroeder, M.P., 2006, Methods of analysis by the U.S. Geological Survey National Water Quality Laboratory-Determination of wastewater compounds in whole water by continuous liquid-liquid extraction and capillary-column gas chromatography/mass spectrometry: U.S. Geological Survey Techniques and Methods, book 5, chap. B4, 30 p. 


\section{Table 5}




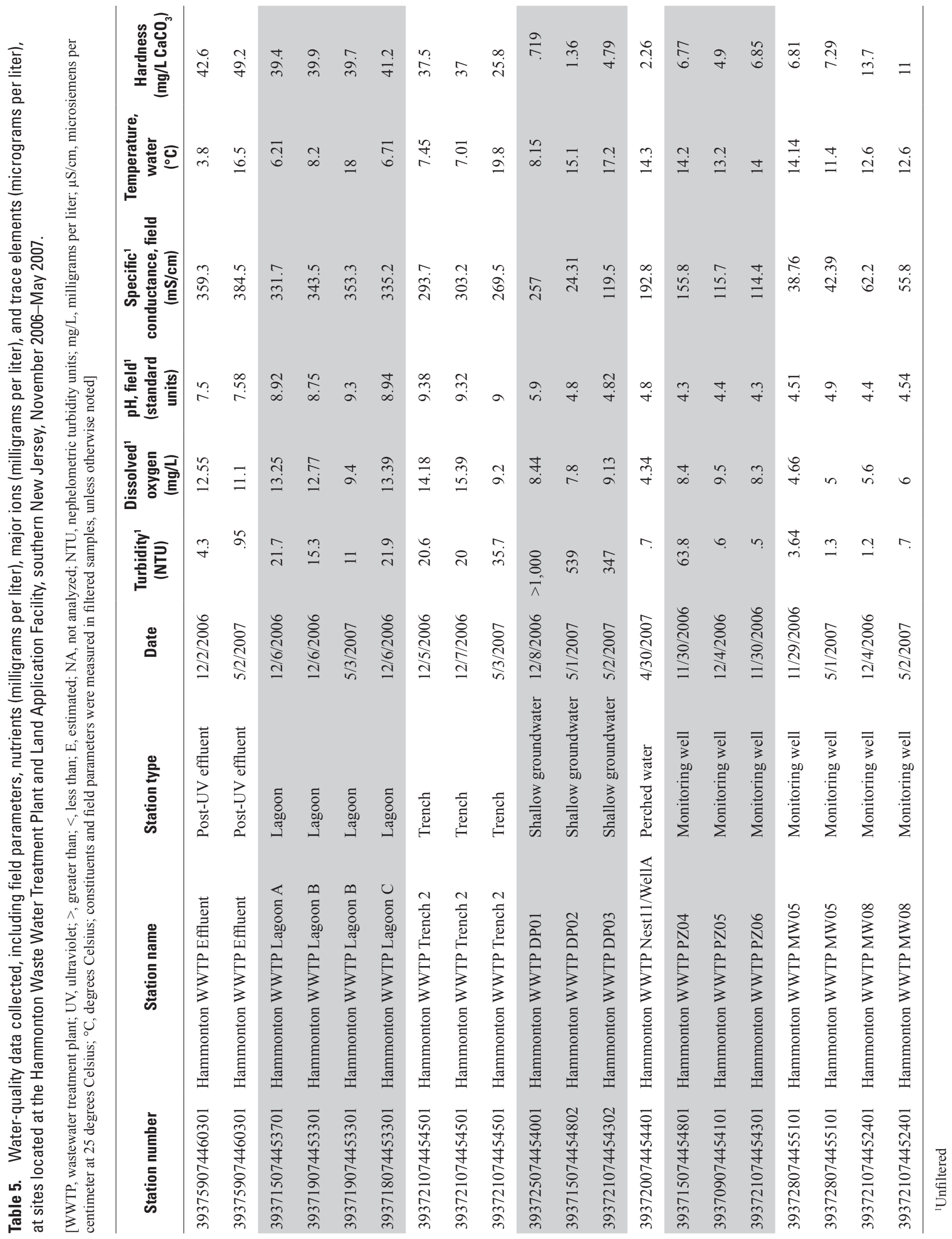


Table 5

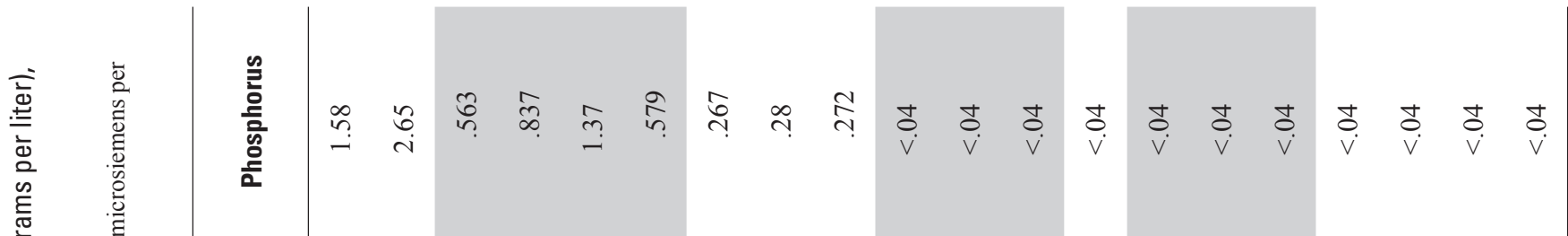
흥 훙 है

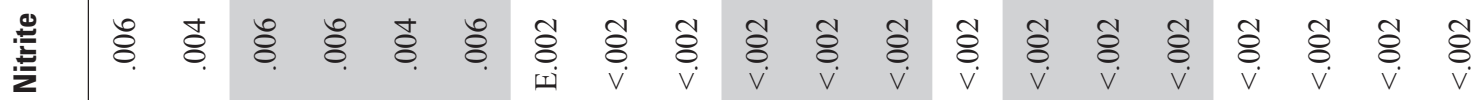

흐 릴

흥 


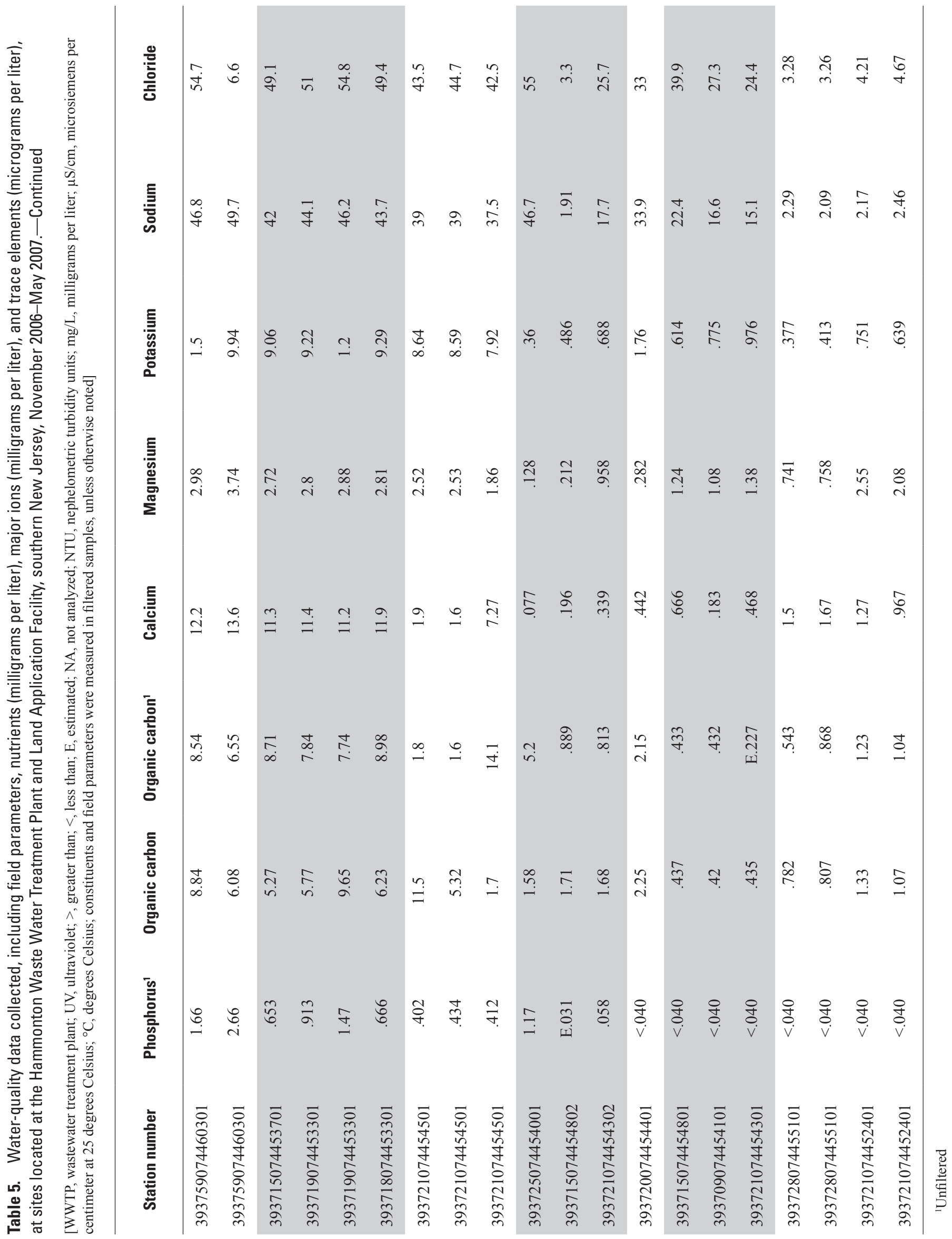




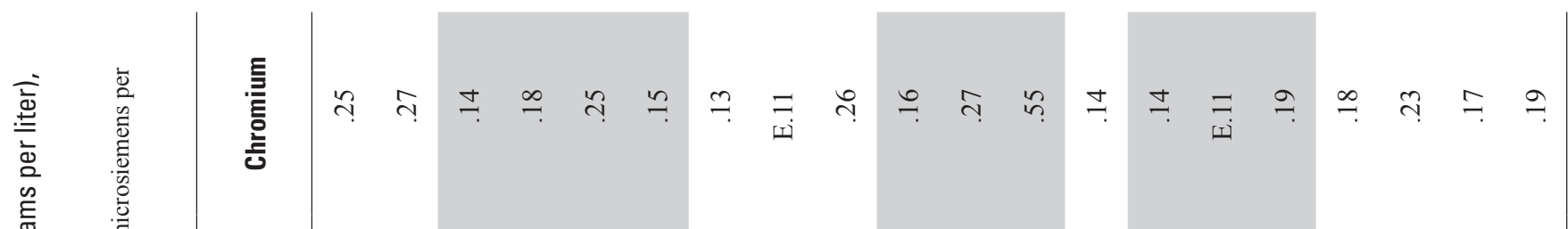

高

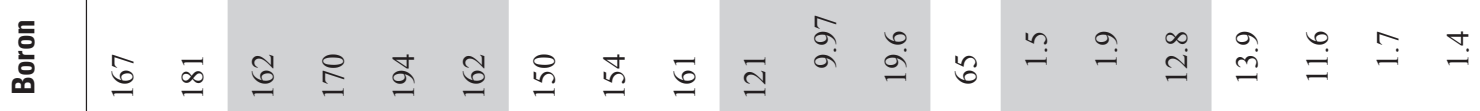

产 


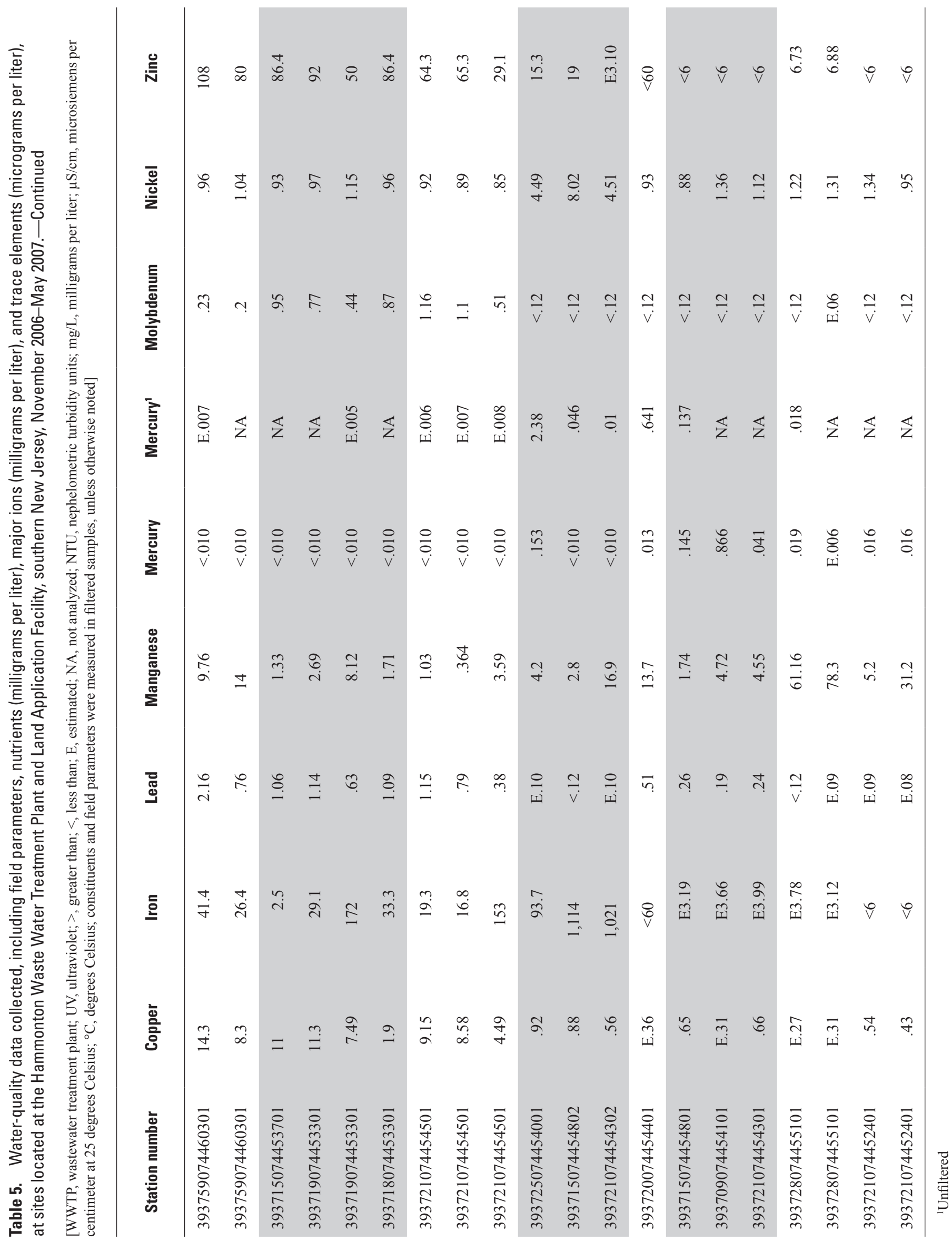




\section{Appendixes}


Appendix 1. Field parameters, nutrients, major ions, and trace elements in samples collected at the Hammonton Waste Water Treatment Plant and Land Application Facility, southern New Jersey, December 2006-May 2007.

[*, water samples analyzed for this constituent were unfiltered; NA, not applicable; $\mu \mathrm{S} / \mathrm{cm}$, microsiemens per centimeter at $25 \mathrm{degrees}$ Celsius; $\mu \mathrm{g} / \mathrm{L}$, micrograms per liter; mg/L, milligrams per liter; RL, reporting limit; Sch, schedule; LC, lab code; Analyses conducted at the U.S. Geological Survey National Water Quality Laboratory (NWQL), Denver, Colorado; lab code (LC), a number that designates a compound and (or) constituent; schedule (Sch), a grouping of lab codes to be measured]

\begin{tabular}{|c|c|c|c|c|}
\hline Constituent or property & $\begin{array}{l}\text { NWQL schedule or } \\
\text { lab code number }\end{array}$ & $\mathbf{R L}$ & Units & Reference \\
\hline $\mathrm{pH}$ & Field & NA & Standard units & 1 \\
\hline Specific conductance & Field & NA & $\mu \mathrm{S} / \mathrm{cm}$ & 1 \\
\hline Dissolved oxygen & Field & NA & $\mathrm{mg} / \mathrm{L}$ & 1 \\
\hline Temperature & Field & NA & degrees Celsius & 1 \\
\hline Ammonia plus organic nitrogen*, as nitrogen & Sch 91 & .1 & $\mathrm{mg} / \mathrm{L}$ & 2 \\
\hline Ammonia, as nitrogen & Sch 91 & .02 & $\mathrm{mg} / \mathrm{L}$ & 3 \\
\hline Nitrite plus nitrate, as nitrogen & Sch 91 & .06 & $\mathrm{mg} / \mathrm{L}$ & 3 \\
\hline Nitrite, as nitrogen & Sch 91 & .002 & $\mathrm{mg} / \mathrm{L}$ & 3 \\
\hline Orthophosphate, as phosphorus & Sch 91 & .006 & $\mathrm{mg} / \mathrm{L}$ & 4 \\
\hline Phosphorus & Sch 91 & .04 & $\mathrm{mg} / \mathrm{L}$ & 3 \\
\hline Phosphorus* & Sch 91 & .04 & $\mathrm{mg} / \mathrm{L}$ & 3 \\
\hline Organic carbon & LC 2613 & .4 & $\mathrm{mg} / \mathrm{L}$ & 3,5 \\
\hline Organic carbon* & LC 114 & .4 & $\mathrm{mg} / \mathrm{L}$ & 3,5 \\
\hline Calcium & Sch 1 & .02 & $\mathrm{mg} / \mathrm{L}$ & 3,5 \\
\hline Chloride & Sch 1 & .014 & $\mathrm{mg} / \mathrm{L}$ & 3,5 \\
\hline Fluoride & Sch 1 & .1 & $\mathrm{mg} / \mathrm{L}$ & 3,5 \\
\hline Magnesium & Sch 1 & .014 & $\mathrm{mg} / \mathrm{L}$ & 3,5 \\
\hline Potassium & Sch 1 & .04 & $\mathrm{mg} / \mathrm{L}$ & 3,5 \\
\hline Silica & Sch 1 & .2 & $\mathrm{mg} / \mathrm{L}$ & 3,5 \\
\hline Sodium & Sch 1 & .2 & $\mathrm{mg} / \mathrm{L}$ & 3,5 \\
\hline Sulfate & Sch 1 & .18 & $\mathrm{mg} / \mathrm{L}$ & 3,5 \\
\hline Aluminum & Sch 344 & 1.6 & $\mu \mathrm{g} / \mathrm{L}$ & $5,6,7,8,9$ \\
\hline Arsenic & Sch 344 & 1.2 & $\mu \mathrm{g} / \mathrm{L}$ & $5,6,7,8,9$ \\
\hline Boron & Sch 344 & 1.8 & $\mu \mathrm{g} / \mathrm{L}$ & $5,6,7,8,9$ \\
\hline Cadmium & Sch 344 & .04 & $\mu \mathrm{g} / \mathrm{L}$ & $5,6,7,8,9$ \\
\hline Chromium & Sch 344 & .12 & $\mu \mathrm{g} / \mathrm{L}$ & $5,6,7,8,9$ \\
\hline Copper & Sch 344 & .4 & $\mu \mathrm{g} / \mathrm{L}$ & $5,6,7,8,9$ \\
\hline Iron & Sch 1 & 6 & $\mu \mathrm{g} / \mathrm{L}$ & $5,6,7,8,9$ \\
\hline Lead & Sch 344 & .12 & $\mu \mathrm{g} / \mathrm{L}$ & $5,6,7,8,9$ \\
\hline Manganese & Sch 1 & .2 & $\mu \mathrm{g} / \mathrm{L}$ & $5,6,7,8,9$ \\
\hline Mercury & Sch 344 & .01 & $\mu \mathrm{g} / \mathrm{L}$ & $5,6,7,8,9$ \\
\hline Mercury* & Sch 344 & .01 & $\mu \mathrm{g} / \mathrm{L}$ & 9 \\
\hline Molybdenum & Sch 344 & .12 & $\mu \mathrm{g} / \mathrm{L}$ & $5,6,7,8,9$ \\
\hline Nickel & Sch 344 & .06 & $\mu \mathrm{g} / \mathrm{L}$ & $5,6,7,8,9$ \\
\hline Zinc & Sch 344 & 6 & $\mu \mathrm{g} / \mathrm{L}$ & $5,6,7,8,9$ \\
\hline
\end{tabular}

${ }^{1}$ Wilde and Radke, 1998

${ }^{2}$ Patton and Truitt, 2000

${ }^{3}$ Fishman, 1993

${ }^{4}$ Patton and Truitt, 1992

${ }^{5}$ Fishman and Friedman, 1989

${ }^{6}$ Garbarino and others, 2006

${ }^{7}$ Struzeski and others, 1996

${ }^{8}$ Brenton and Arnett, 1993

${ }^{9}$ Garbarino and Damrau, 2001 
Appendix 2. Wastewater indicator compounds ${ }^{1}$ measured in samples collected at the Hammonton Waste Water Treatment Plant and Land Application Facility, southern New Jersey, December 2006-May 2007.

[All concentrations in micrograms per liter; analyses conducted at the U.S. Geological Survey National Water Quality Laboratory (NWQL), Denver, Colorado (schedule 4433); samples for all analyses were unfiltered]

\begin{tabular}{|c|c|c|c|}
\hline Compound & Reporting limit & Compound & Reporting limit \\
\hline 2,6-Dimethylnaphthalene & .2 & Diethoxyoctylphenol $^{2}(\mathrm{OPEO} 2)$ & .32 \\
\hline 3,4-Dichlorophenyl isocyanate & 1.6 & D-Limonene & .2 \\
\hline 3-beta-Coprostanol & .8 & Fluoranthene & .2 \\
\hline 4-Cumylphenol & .2 & Isoborneol & .2 \\
\hline 4-n-Octylphenol & .2 & Isophorone & .2 \\
\hline 4-Nonylphenol & 1.6 & Isoquinoline & .2 \\
\hline 4-tert-Octylphenol & .4 & Menthol & .2 \\
\hline Anthracene & .2 & Monoethoxynonylphenol (all isomers) (NPEO1) & 2 \\
\hline 9,10 -Anthraquinone & .2 & Monoethoxyoctylphenol (OPEO1) & 1 \\
\hline Atrazine & .2 & p-Cresol & .2 \\
\hline BDE congener 47 & .2 & Pentachlorophenol & .8 \\
\hline Benzo[a]pyrene & .2 & Phenanthrene & .2 \\
\hline Benzophenone & .2 & Phenol & .2 \\
\hline beta-Sitosterol & .8 & Prometon & .2 \\
\hline beta-Stigmastanol & .8 & Pyrene & .2 \\
\hline Bis(2-ethylhexyl) phthalate & 2 & Tributyl phosphate & .2 \\
\hline Chlorpyrifos & .2 & 1,4-Dichlorobenzene & .2 \\
\hline Cholesterol & .8 & Isopropylbenzene & .2 \\
\hline Cotinine & .8 & Naphthalene & .2 \\
\hline N,N-diethyl-meta-toluamide (DEET) & .2 & Tetrachloroethene & .4 \\
\hline Diazinon & .2 & Tribromomethane & .2 \\
\hline Dichlorvos & .2 & & \\
\hline
\end{tabular}

Zaugg and others, 2006

27-Acetyl-1,1,3,4,4,6-hexamethyl tetra hydro naphthalene

${ }^{3} 1,3,4,6,7,8$-Hexahydro 4,6,6,7,8,8-hexamethyl cyclopenta-4-2-benzopyran 


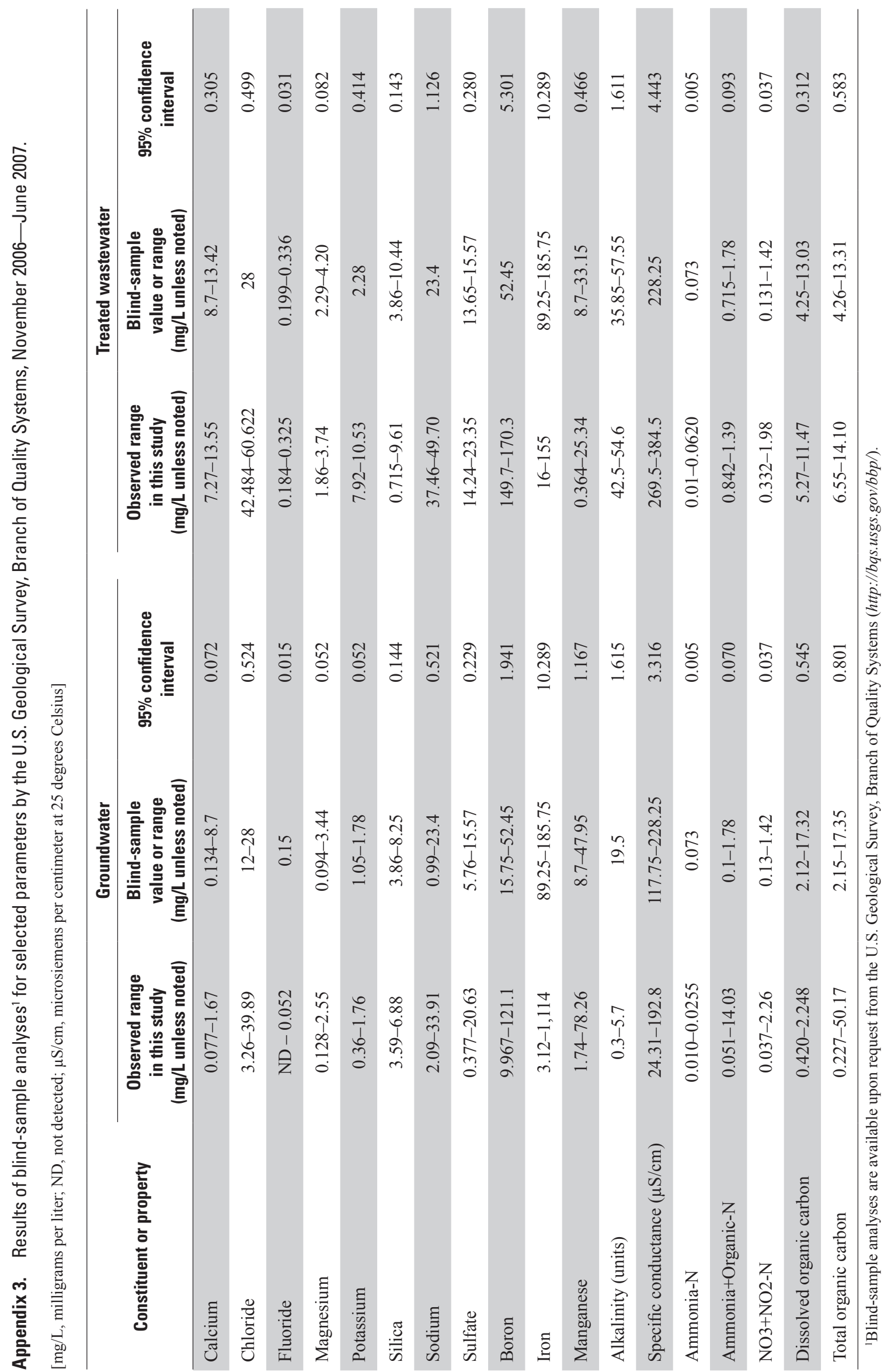




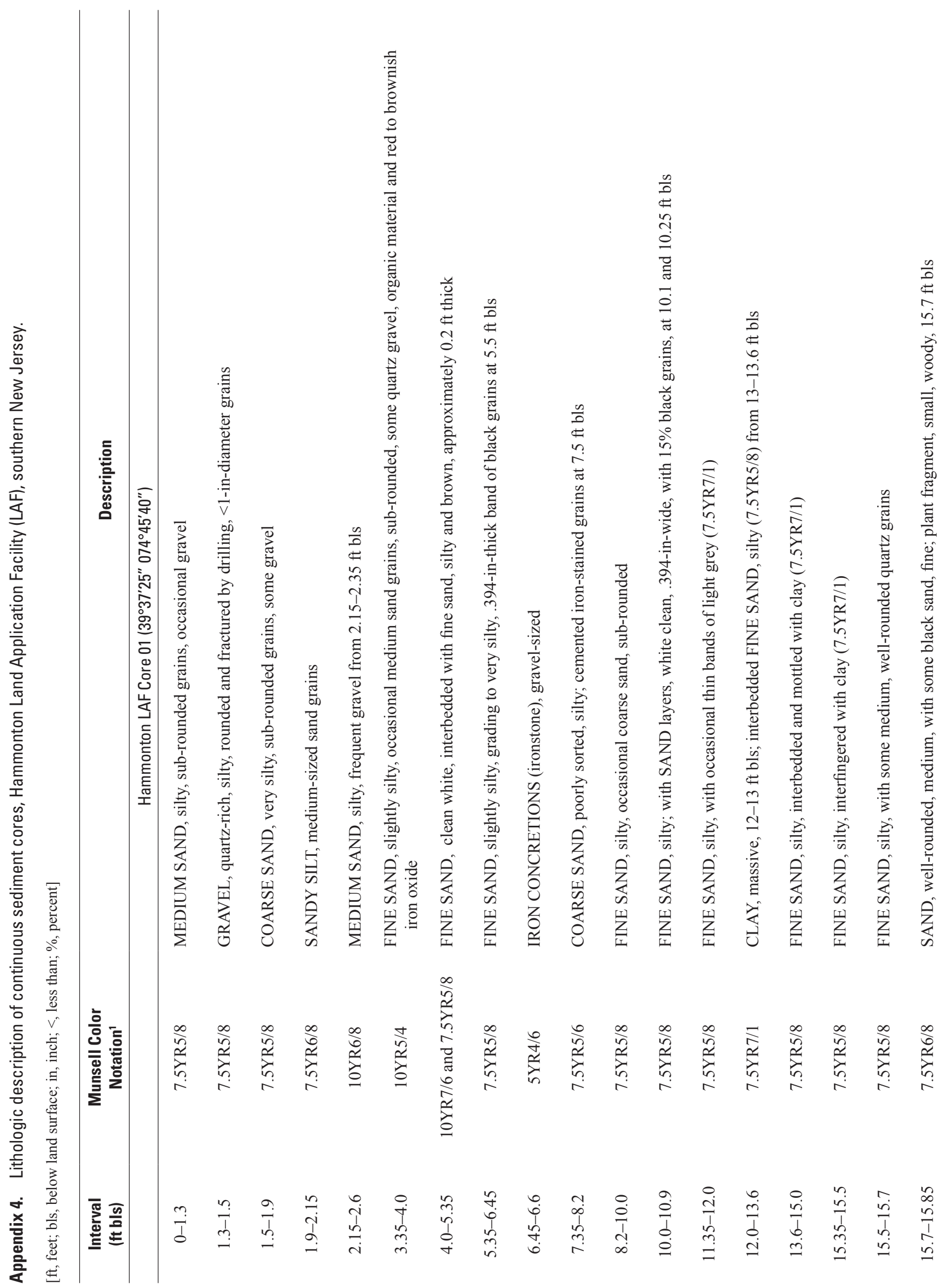




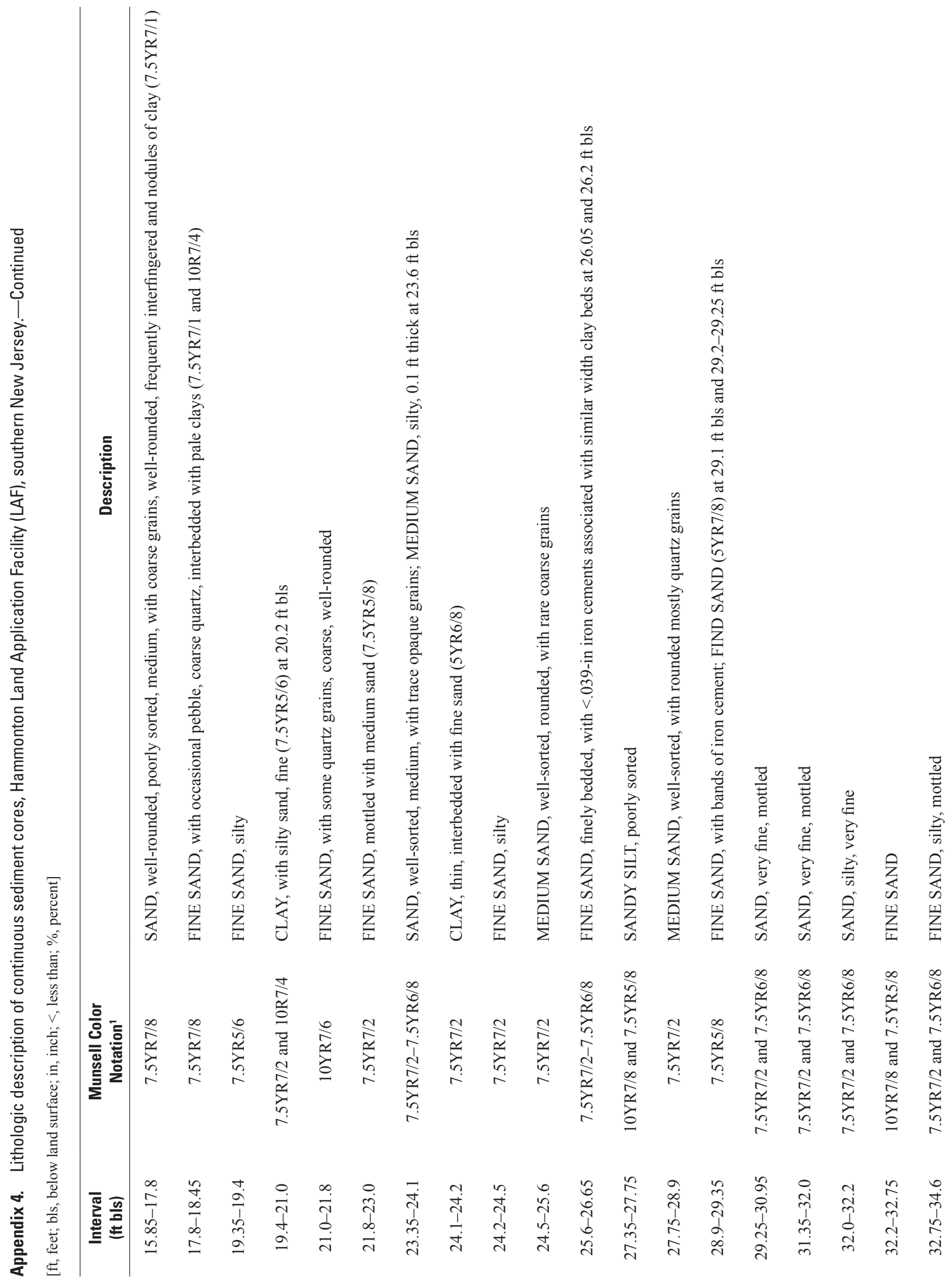




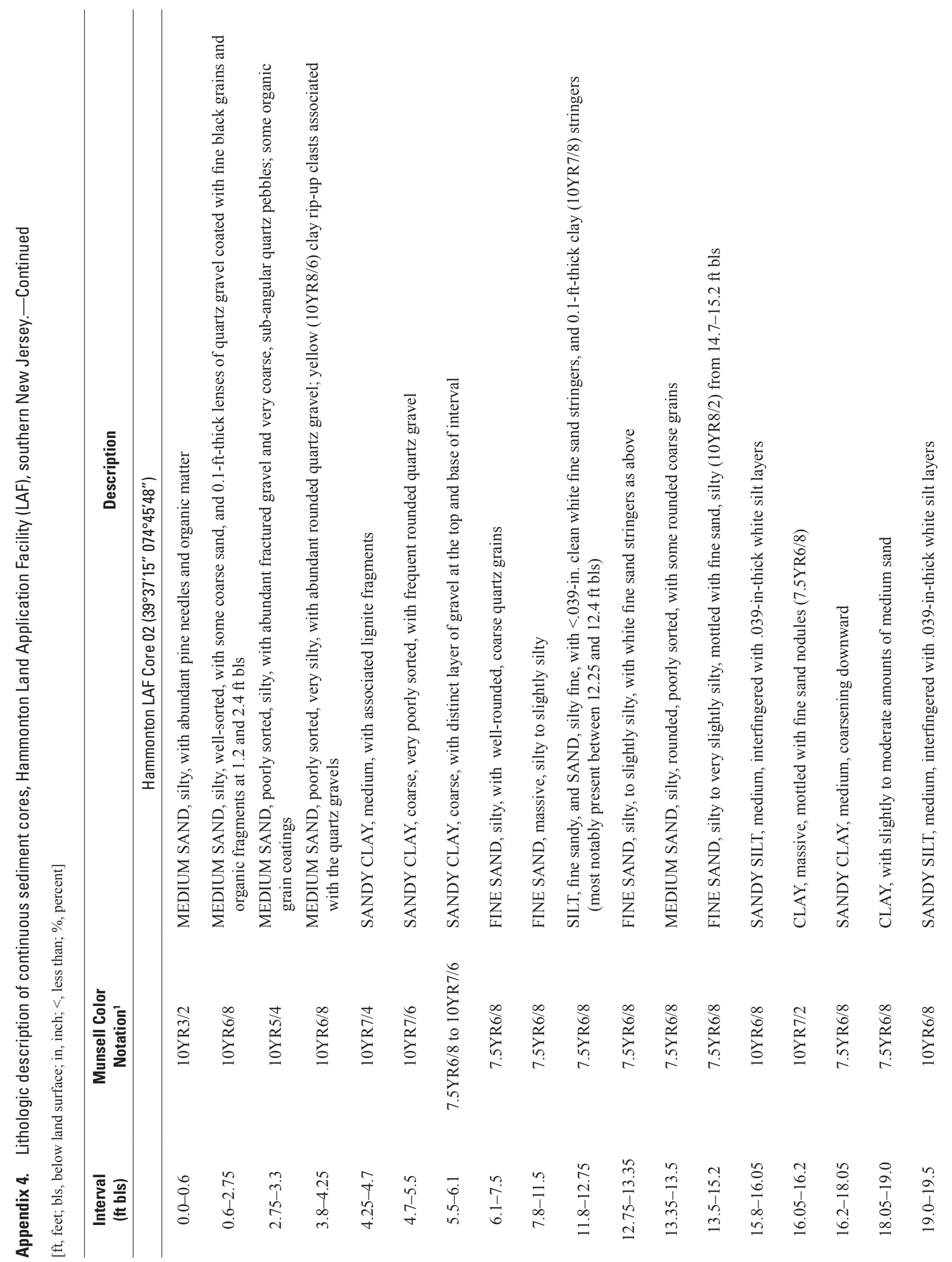




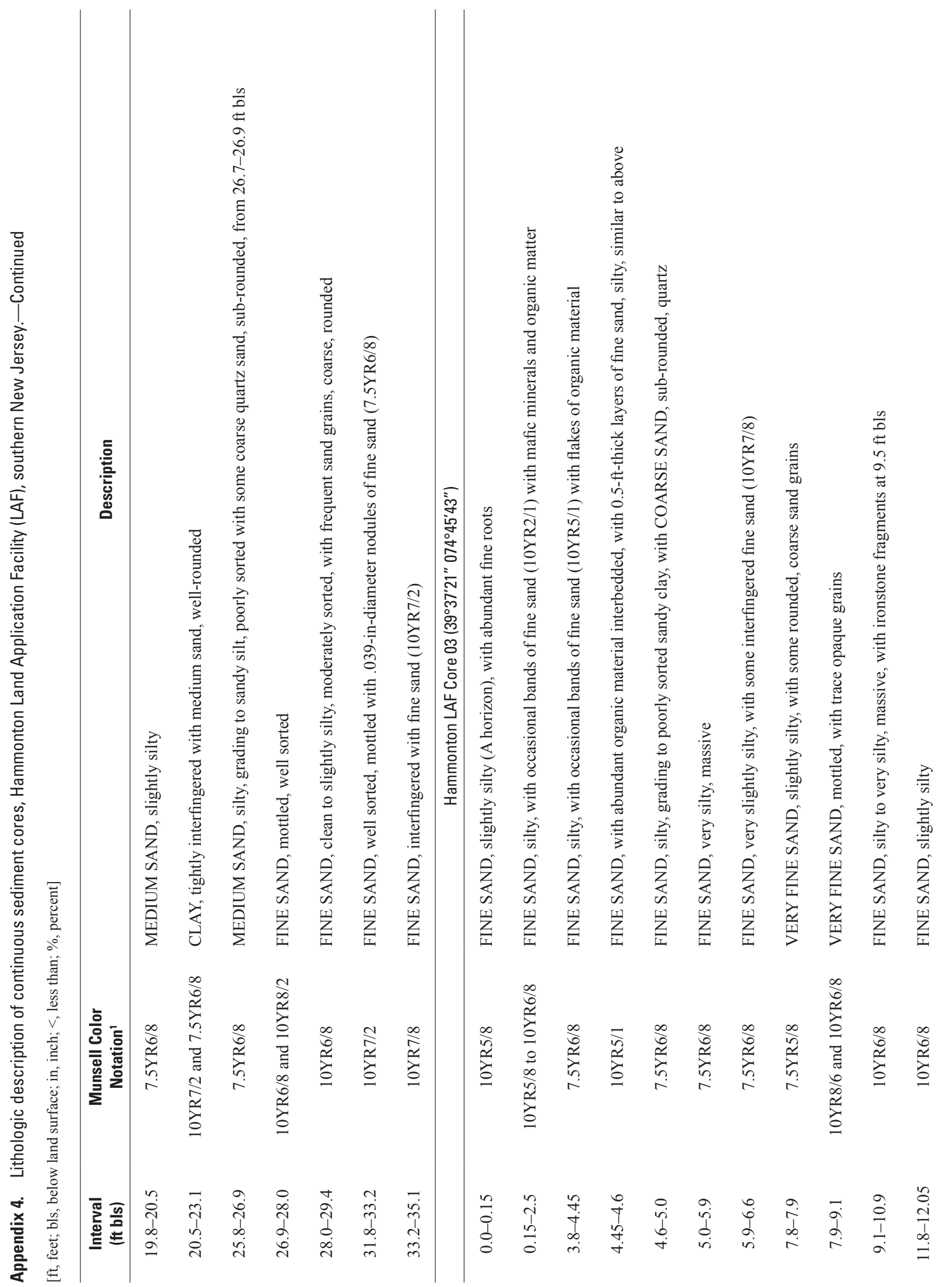




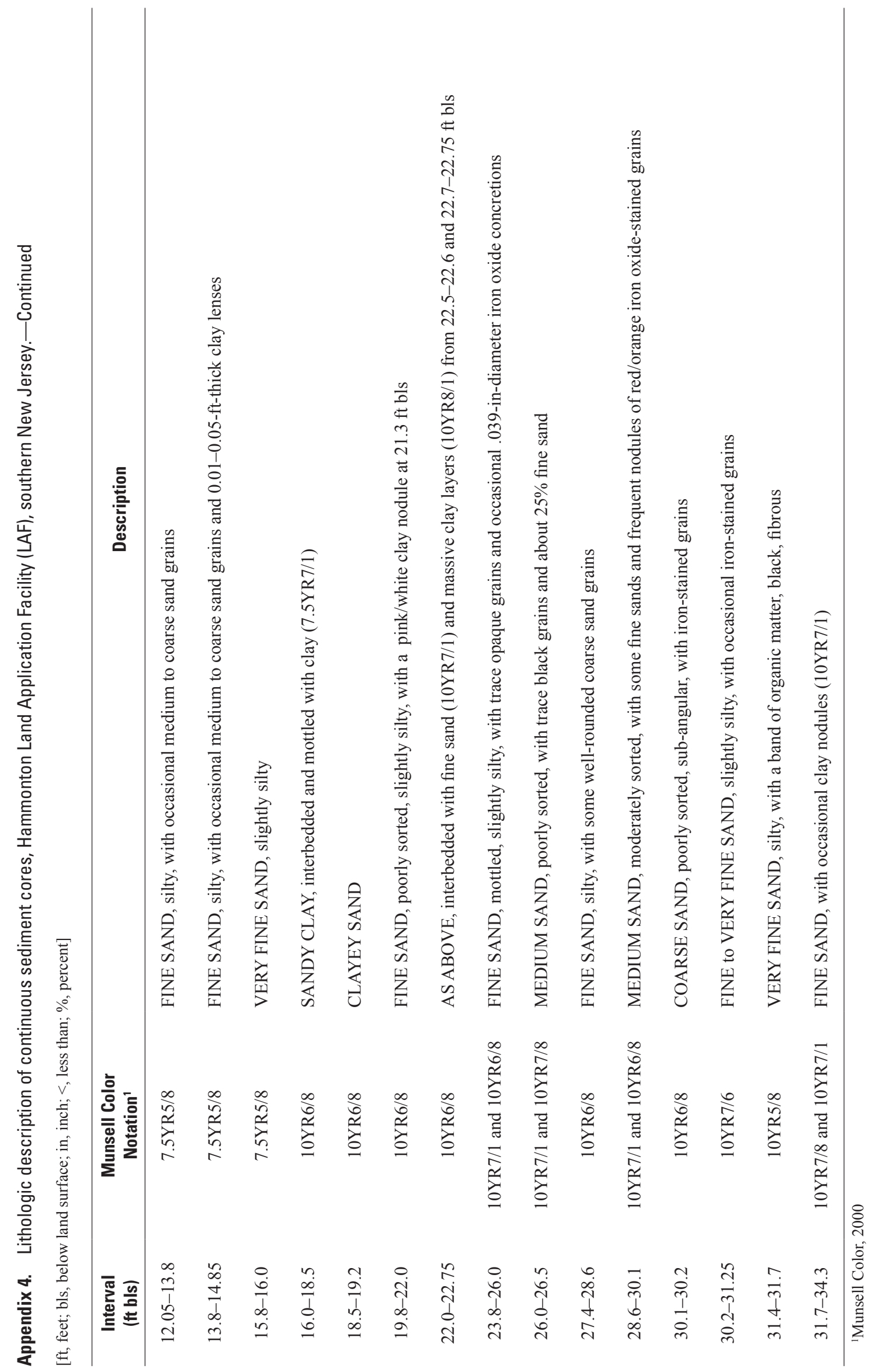



For additional information, write to:

Director, U.S. Geological Survey

New Jersey Water Science Center

810 Bear Tavern Road, Suite 206

West Trenton, NJ 08628

or visit our Web site at:

http://nj.usgs.gov/ 
